\title{
COINS OF THE OTTOMAN SULTANS FOUND IN THE TERRITORY OF THE CZECH REPUBLIC FROM 1996 TO 2018
}

\author{
Vlastimil Novák ${ }^{\dagger}$
}

\begin{abstract}
Ottoman coins have been registered in the Czech Lands since the beginning of the $18^{\text {th }}$ century and have been systematically documented since the mid- $19^{\text {th }}$ century. The latest actualization comes from 1996, but the following massive use of metal detectors showed a serious need for a new summarization. Up until 2018, some 151 hoards/ single finds with the Ottoman coins, forgeries, and jetons have been registered in the territory of the Czech Republic. These coins came to the mentioned territory via the Ottoman European expansion since the $16^{\text {th }}$ century, and their flow reached its peak in the $17^{\text {th }}$ century. The massive appearance of the Ottoman coins in Bohemia, partly in Moravia and Silesia, in the $17^{\text {th }}$ century represents a phenomenon connected with the Thirty Years War. In south and central Moravia, it is explained by the direct military impact of the Ottoman armies. The later import of these coins is associated with the Napoleonic Wars and with the Austro-Hungarian period through its Balkan connection.
\end{abstract}

KEYWORDS: Ottoman Sultans - coins - single finds - hoards - forgery - jeton Thirty Years War $-16^{\text {th }}-19^{\text {th }}$ centuries - Czech Republic

\section{Introduction}

The coins ${ }^{1}$ struck under the Ottoman Sultans (previously described as the Turkish coins) started to come to Bohemia, Moravia, and Silesia in connection with the aggressive Ottoman European expansion in the $16^{\text {th }}$ century. Their flow reached its peak in the $17^{\text {th }}$ century. In Bohemia, partly in Moravia and Silesia, they are connected with the Thirty Years War, and in south and central Moravia, their appearance is explained by the direct military impact of the Ottoman (and Tartar) element. Since the second half of the $19^{\text {th }}$ century, the Ottoman coins have been sporadically registered in the individual specialized articles, and in the 1950s, they were summarized in four complex volumes generally covering all coin hoards in the territory of Bohemia, Moravia, and Silesia. ${ }^{2}$ In the 1960s, J. Štěpková offered an extensive survey of the Ottoman coins found in the territory of Czechoslovakia of that time. ${ }^{3}$ Later on, she actualized the list of the newly discovered Ottoman pieces in Slovakia. ${ }^{4}$ In the Czech lands, the tradition of the systematic publishing of all newly found coins stopped in the 1980s in connection with the interrupted series of the Numismatický sborník (published again since 2005).

1 The manuscript was edited under the supervision of Jiří Militký and Dorota Malarczyk. This work was financially supported by Ministry of Culture of the Czech Republic (DKRVO 2019-2023/11.VI.b, National Museum, 00023272).

2 Nohejlová-Prátová 1955-1958.

3 Štěpková 1963.

4 Štěpková 1968.

This work is licensed under the Creative Commons Attribution-Noncommercial-No Devivs 3.0 License 
Since the 1990s, the situation in monitoring of coin hoards has changed completely: the unreformed, restrictive, and rigid legislation could not respond to development and massive private use of modern prospection technologies (metal detectors). Information about hoards rapidly increased, but its credibility, quality, and value decreased due to the usual reluctance of finders to cooperate. Focusing on the significant and numerous activities of clubs - mostly operating on the internet - it is possible to gain a reasonable quantity of data, but without the precise provenance, mostly without metrology, and with non-standard photographs. In spite of all these facts, some gradual attempts to summarize officially the Ottoman coins found in the new millennium have been made. ${ }^{5}$ This article is primarily aimed at the most detailed list possible covering the Ottoman coins found in the territory of the Czech Republic between 1996 and 2018 based on official sources (publications, reported unpublished coins) and also on the prevailing unofficial sources such as different websites of various amateur clubs and numerous claims for the attribution of coins. All of the data used in the text should help in the interpretation of these coins in the mentioned historical context of the studied region.

\section{Characteristic Features of the Ottoman coinage}

The coins of the Ottoman sultans are characterized as Islamic issues. They bear inscriptions in Arabic, and their religious legends are based on Islamic ideology. Their mono-epigraphic legends have typical calligraphic characters. Basically, their obverse legends present the Ottoman sultan's name with all the necessary titles and epithets, the particular religious formulas inclusive. The name of the ruler is performed in the form called tughrā, which is a stylized signature used as the state symbol and the ruler's emblem. The reverse bears standard legends with the mint name and the Hijra date in numeral form. ${ }^{6}$ Between 1390 and 1481, the silver coins were dated in irregular intervals (the so-called serial dating). After 1481, the coins only had the date of enthronization, and basically, they had been struck during the entire ruler's era (i.e., the coins struck between 1481 and 1787 can be dated only by the interval of rule of a particular ruler. ${ }^{7}$ In some cases - based on the archaeological data - it is possible to precisely specify the time span for activities of the individual mints. ${ }^{8}$ Starting with the mid- $18^{\text {th }}$ century, the concrete production year has also been added to the enthronization date. The significant variability of coinage derived from the territorial expansion, and evolution of the denomination structure copied the systems of the surrounding countries to a considerable extent. The specific content of precious metals in coins was absolutely dependent on the economic stability and military success of the entire Ottoman Empire. Since the $14^{\text {th }}$ century, the Ottoman monetary system from its very beginning has been exclusively based on silver. In 1327, during the rule of Sultan Orhan, the production of silver coins called akçe started. Their weight was about $1.16 \mathrm{~g}$, and they contained about $90 \%$ of silver. Since the second half of the $15^{\text {th }}$ century, their weight started to decrease significantly, and their content of silver decreased as well. Similarly as in other parts of Europe (mainly in the Mediterranean), also in the Ottoman empire, various types of non-Islamic silver coins circulated. They were generally called qurush (sg. qirsh) -

\footnotetext{
Novák 2006; Novák 2011.

Novák 2000.

Album 2011.

8 Damali 2010-2012.
} 
derived from the Latin grossus. Also gold coins were very popular; the Venetian ducats were called filuri (derived from Italian florin) and the Hungarian ducats were called macar altini (an exact Turkish translation for the Hungarian ducats). The mentioned ducats served as prototypes for coins called altin or sultani. Their minting started in 1451-1481. After the occupation of Egypt (1516), massive production of high quality gold coins of the sultani type began, and their weight (in contrast with silver) was stabilized for more than two hundred years at $3.286 \mathrm{~g}$, and because of their quality, they became very popular in Europe during the Thirty Years War. The Ottoman copper coins, labeled by the Mongolian word manghirs, differentiated individually from each other in weight, and they were characteristic by their very simple iconography (heraldic symbols, floral ornaments, or only the sultan's name). A radical decrease in the quality of the silver akçe at the beginning of the $16^{\text {th }}$ century initiated the introduction of a new denomination - para (equal to 3-4 akçes). Besides these coins, silver dirhams (about $3 \mathrm{~g}$ ) were struck in the Middle East. The gradual debasing of silver led to the introduction of new silver denominations in 1687-1691 - qirsh (called also piaster, equal to 40 paras) and zolota (equal to 30 paras). The following Ottoman monetary history was characterized by the growing number of denominations, of which mainly gold coins had a more or less representative character. There is a problem with the absence of declared denominations on the flan starting with the $18^{\text {th }}$ century, which is quite complicated in the case when there is a lack of metrological data for the archaeological numismatic material. Thus the attribution of the undeclared denomination is only based on the size and weight of a particular coin.

\section{Ottoman Coins Found in Bohemia, Moravia, and Silesia}

Ottoman coins found in the territory of the Czech Republic cover the time span between the $14^{\text {th }}$ and $20^{\text {th }}$ centuries. In general, the structure of the Ottoman coins buried since the end of the $16^{\text {th }}$ century to the second half of the $18^{\text {th }}$ century differs in Bohemia and Moravia, which is a result of different histories of both territories. Bohemia - compared to Moravia - had never been directly endangered by the Ottoman enemy. Moravia was attacked by the Turks (together with the Tartars) in 1599 for the first time. They reached the Moravian Valacchia, and the Moravian military forces stopped them as far as near Javornik. Later on in 1623, with support of the Turks, the Duke of Transylvania Gabor Bethlen broke through to Znojmo, Brno, and Olomouc. The worst attacks came in 1663, when the Turks destroyed in three waves the south-eastern part of Moravia first, then they reached Velké Meziříčí, and the third attack totally devastated Valacchia (Klobouky, Vizovice, Vsetín, Krásno). The last serious threat for Moravia dates to 1683, when during the siege of Vienna, the Turkish-Tartar troops endangered Brno and Přerov. ${ }^{9}$

\section{Tab. 1. An up-to-date list of the Ottoman sultans whose coins were found in the territory of the Czech Republic.}

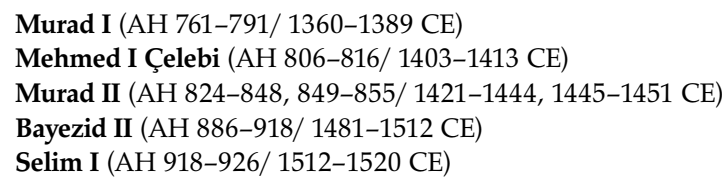

9 Tauer 1984; Čapka 1998. 
Suleiman I (AH 926-974/ 1520-1566 CE)

Selim II (AH 974-982/ 1566-1574 CE)

Murad III (AH 982-1003/ 1574-1595 CE)

Mehmed III (AH 1003-1012/ 1595-1603 CE)

Ahmed I (AH 1012-1026/ 1603-1617 CE)

Osman II (AH 1027-1031/ 1618-1622 CE)

Murad IV (AH 1032-1049/ 1623-1640 CE)

Ibrahim I (AH 1049-1058/ 1640-1648 CE)

Mehmed IV (AH 1058-1099/ 1648-1687 CE)

Ahmed III (AH 1115-1143/ 1703-1730 CE)

Mustafa III (AH 1171-1187/ 1757-1774 CE)

Selim III (AH 1203-1222/ 1789-1807 CE)

Mahmud II (AH 1223-1255/ 1808-1839 CE)

Abdulmejid I (AH 1255-1277/ 1839-1861 CE)

Abdulaziz (AH 1277-1293/ 1861-1876 CE)

Murad V (AH 1293/ 1876 CE)

Abdulhamid II (AH 1293-1327/ 1876-1909 CE)

Mehmed V (AH 1327-1336/ 1909-1918 CE)

Mehmed VI (AH 1336--1341/ 1918-1923 CE)

Based on the data registered up until 1996, gold coins absolutely dominate among the Ottoman pieces found in Bohemia, Moravia, and Silesia. The decisive majority of those finds are of a group character (hoards), and they are evidently connected with the turbulent times of the Thirty Years War (1618-1648) and the period closely after that. The gold Ottoman coins had not been melted in the mentioned territory, and were minted again simply due to the high quality of the coin's metal (the gold gained by the Ottomans in Egypt in 1516). They appeared in hoards since the end of the $16^{\text {th }}$ century up to the very end of the $18^{\text {th }}$ century. Their precise production dating is complicated because of the exclusively presented dates of enthronization. Generally, they are represented by issues struck between 1520 to 1640 . The gold Ottoman denominations of the sultani type ${ }^{10}$ are most massively incorporated in mixed group finds (hoards). In the case of the hoards with more Ottoman gold coins, a higher territorial diversity of mints is clearly visible, which points to a relatively long period of circulation of these coins and a significant scale of selection from their territorial production. The Ottoman gold coins in hoards, or as single finds, show heavy wear and traces of breaking or testing.

The Ottoman coins are regularly dispersed all over the Bohemian territory. In Moravia, these coins appear to the north of the following line: Jihlava - Brno - Přerov - Vsetín. They have been buried more or less evidently in connection with the Thirty Years War. In the territory situated to the south of the mentioned line, the coins found there can be very likely connected directly with the Ottoman military activities. The Ottoman copper coins are registered in Bohemia and Moravia as single finds and represent the late modern random import (Tab. 2, nos. 44, 46). Similarly, the silver coins there can be regarded as a quality admixture of peripheral character in the thesaurization hoards (Tab. 2, nos. 11, $32,36,39)$. The Ottoman high-quality gold coins (of the sultani type) - minimally mixed with silver pieces ( 2 hoards) - are documented in the absolute majority of hoards (34 hoards) in Bohemia and Moravia. The gold coins found as single ( 3 pieces, Tab. 2, nos. $1,2,37)$ in the periphery of the studied territory very likely confirm the above-described distribution, and in a way, they can point to Prague as a contemporary historical centre. 
Tab. 2: Ottoman coins found in Bohemia, Moravia and Silesia, published up to 1996 (after Novák 2006, 182-183, Štěpková 1963, listing based on terminus post quem).

\begin{tabular}{|c|c|c|c|c|c|c|}
\hline No. & Locality & $\begin{array}{l}\text { Total number } \\
\text { of coins }\end{array}$ & $\begin{array}{c}\text { Ottoman coins, } \\
\text { dating }(C E)\end{array}$ & Mint & $\begin{array}{c}\text { Terminus } \\
\text { post quem } \\
\text { (CE) }\end{array}$ & $\begin{array}{l}\text { Date of } \\
\text { discovery/ } \\
\text { literature }\end{array}$ \\
\hline 1. & \begin{tabular}{|l|} 
Chvalkovice \\
(Náchod distr.)
\end{tabular} & $\begin{array}{l}\text { SF (Single } \\
\text { find) } 1 \mathrm{AV}\end{array}$ & $\begin{array}{l}1 \mathrm{AV}, \\
1520-1566\end{array}$ & Sidre Qapisi & after 1566 & $\begin{array}{l}\text { 1954/ Štěpková } \\
\text { 1957, pp. 213- } \\
214\end{array}$ \\
\hline 2. & \begin{tabular}{|l} 
Třeština, \\
Hájský Mlýn \\
Settlement \\
(沗perk \\
distr.) \\
\end{tabular} & SF $1 \mathrm{AV}$ & $\begin{array}{l}1 \mathrm{AV}, \\
1520-1566\end{array}$ & Misr & after 1566 & $\begin{array}{l}\text { 1891/ Nálezy } \\
\text { III/1, no. } 2971\end{array}$ \\
\hline 3. & \begin{tabular}{|l|} 
Velká Bíteš \\
(Žd'ár nad \\
Sázavou distr.)
\end{tabular} & $\begin{array}{l}\mathrm{H} \text { (Hoard) } 3 \\
\mathrm{AV}\end{array}$ & $\begin{array}{l}1 \mathrm{AV}, \\
1574-1595\end{array}$ & Misr & $\begin{array}{l}\text { after } \\
1574 / 1595\end{array}$ & $\begin{array}{l}\text { 1961/ Štěpková } \\
\text { 1963, p. } 151\end{array}$ \\
\hline 4. & Olomouc I & H $3 \mathrm{AV}$ & \begin{tabular}{|l}
$\mathrm{AV}$, \\
$1603-1617$
\end{tabular} & Qustantiniya & after 1605 & $\begin{array}{l}\text { 1900/ Nálezy } \\
\text { III/1, no. } 3030\end{array}$ \\
\hline 5. & $\begin{array}{l}\text { Habř́í (České } \\
\text { Budějovice } \\
\text { distr.) }\end{array}$ & H 115 AV & $\mathrm{xAV}$ & - & after 1606 & $\begin{array}{l}\text {-/ Nálezy III/1, } \\
\text { no. } 3033\end{array}$ \\
\hline 6. & \begin{tabular}{|l} 
Záluží (Praha- \\
Východ distr.)
\end{tabular} & $\mathrm{H} 3 \mathrm{AV}+3 \mathrm{AR}$ & $1 \mathrm{AV}$ & - & after 1610 & $\begin{array}{l}\text { 1931/ Nálezy } \\
\text { III/1, no. } 3047\end{array}$ \\
\hline 7. & Praha I & H 384 AV & \begin{tabular}{|l|}
$8 \mathrm{AV}$, \\
$1360-1574$ \\
\end{tabular} & - & after 1616 & $\begin{array}{l}\text { 1907/ Nálezy } \\
\text { III/1, no. } 3075 \\
\end{array}$ \\
\hline 8. & \begin{tabular}{|l|} 
Kamenice \\
nad Lipou, \\
Koblížek Forest \\
(Pelhřimov \\
distr.)
\end{tabular} & H $476 \mathrm{AV}$ & $\begin{array}{l}29 \mathrm{AV}, \\
1520-1566 \\
1566-1574, \\
1574-1595, \\
1595-1603, \\
1603-1617\end{array}$ & $\begin{array}{l}\text { 1520-1566/ } \\
\text { Amid, Sidre } \\
\text { Qapisi, } \\
\text { Qustantiniya, } \\
\text { 3 Misr, 1566- } \\
\text { 1574/Halab, } \\
\text { Dimashq, } \\
\text { Srebrenitcha, } \\
\text { 2 Misr, } \\
\text { 1574-1595/ } \\
\text { Baghdad, } \\
\text { Jazair, } \\
\text { Handja, } \\
\text { Tarabulus, } \\
\text { 5 Misr, } \\
\text { 1595-1603/ } \\
\text { Amid, Halab, } \\
\text { Saqiz, 3 Misr, } \\
\text { 1603-1617/ } \\
\text { Tuqat, Halab, } \\
\text { Dimashq }\end{array}$ & after 1618 & $\begin{array}{l}\text { 1922/ Fiala 1922, } \\
\text { pp. 170-171; } \\
\text { Augst 1958, pp. } \\
92-96\end{array}$ \\
\hline 9. & \begin{tabular}{|l|} 
Horní \\
Vltavice, \\
Záton̆ \\
Settlement \\
(Prachatice \\
distr.) \\
\end{tabular} & $\begin{array}{l}\mathrm{H} \times \mathrm{AV}+\mathrm{AR} \\
\text { (6 AV + 2 AR } \\
\text { described })\end{array}$ & $2 \mathrm{AV}$ & - & \begin{tabular}{|l|} 
after \\
$1618 / 1648$
\end{tabular} & $\begin{array}{l}\text { 1726/ Nálezy } \\
\text { III/1, no. } 3475\end{array}$ \\
\hline 10. & Plzeň & $\begin{array}{l}\mathrm{H} \times \mathrm{AV}(1801 \\
\text { described) }\end{array}$ & $129 \mathrm{AV}$ & - & $\begin{array}{l}\text { after } \\
1618 / 1619 \\
\end{array}$ & $\begin{array}{l}\text { 1912/ Nálezy } \\
\text { III/1, no. } 3186\end{array}$ \\
\hline 11. & Praha II & $\begin{array}{l}\text { H } 4 \text { AV + } 17 \\
\text { AR }\end{array}$ & $4 \mathrm{AV}+17 \mathrm{AR}$ & - & $\begin{array}{l}\text { after } \\
1618 / 1648\end{array}$ & $\begin{array}{l}\text { 1908/ Nálezy } \\
\text { III/1, no. } 3509\end{array}$ \\
\hline
\end{tabular}




\begin{tabular}{|c|c|c|c|c|c|c|}
\hline 12. & \begin{tabular}{|l|} 
Uničov \\
(Olomouc distr.)
\end{tabular} & $\begin{array}{l}\text { H } 352 \mathrm{AV}(176 \\
\text { described) }\end{array}$ & \begin{tabular}{|l}
$25 \mathrm{AV}$, \\
$1520-1566$, \\
$1566-1574$, \\
$1574-1595$, \\
$1595-1603$, \\
$1603-1617$
\end{tabular} & \begin{tabular}{|l|} 
1520-1566/ \\
Amasiya, 2 \\
Misr, 1566- \\
1574/ Misr, \\
1574-1595/ \\
Dimashq, 5 \\
Misr, 4 X, \\
1595-1603/ \\
Baghdad, \\
Dimashq, \\
Misr, 5 X, \\
1603-1617/2 \\
Qustantiniya, \\
Misr \\
\end{tabular} & \begin{tabular}{|l|} 
after \\
$1618 / 1648$
\end{tabular} & $\begin{array}{l}\text { 1911/ Nálezy } \\
\text { III/1, no. } 3533\end{array}$ \\
\hline 13. & Přerov & $\begin{array}{l}\text { H } 26 \mathrm{AV}+ \\
2364 \mathrm{AR}\end{array}$ & $\begin{array}{l}2 \mathrm{AV}, \\
1574-1595, \\
1595-1603\end{array}$ & \begin{tabular}{|l|}
$1574-1595 /$ \\
Saqiz, \\
1595-1603/ \\
Qustantiniya
\end{tabular} & after 1623 & $\begin{array}{l}\text { 1923/ Nálezy } \\
\text { III/1, no. } 3250 \\
\text { Chumchal } 1994\end{array}$ \\
\hline 14. & \begin{tabular}{|l} 
Raškovice \\
(Frýdek-Místek \\
distr.)
\end{tabular} & H $68 \mathrm{AV}$ & \begin{tabular}{|l}
$2 \mathrm{AV}$ \\
$1574-1595$ \\
$1603-1617$
\end{tabular} & \begin{tabular}{|l|}
$1574-1595 /$ \\
Misr, \\
$1603-1617 /$ \\
Qustantiniya \\
\end{tabular} & after 1624 & $\begin{array}{l}\text { 1844/ Nálezy } \\
\text { III/1, no. } 3264\end{array}$ \\
\hline 15. & \begin{tabular}{|l|} 
Chlumětín \\
(Žd'ár n. \\
Sázavou distr.)
\end{tabular} & $\begin{array}{l}\mathrm{H}+350 \mathrm{AV} \\
\text { and AR (305 } \\
\text { described) }\end{array}$ & $\begin{array}{l}4 \mathrm{AV}, \\
1512-1520, \\
1595-1603, \\
1603-1617 \\
\end{array}$ & \begin{tabular}{|l|}
$1512-1520 /-$ \\
$1595-1603 /-$, \\
$1603-1617 /$ \\
Qustantiniya
\end{tabular} & after 1627 & $\begin{array}{l}\text { 1925/ Nálezy } \\
\text { III/1, no. } 3289\end{array}$ \\
\hline 16. & \begin{tabular}{|l} 
Potěhy \\
(Kutná Hora \\
distr.)
\end{tabular} & $\begin{array}{l}\text { H } 26 \mathrm{AV}+5 \\
\text { AR }\end{array}$ & $10 \mathrm{AV}$ & - & after 1627 & $\begin{array}{l}\text { 1887-1888/ } \\
\text { Nálezy III/1, no. } \\
3292\end{array}$ \\
\hline 17. & $\begin{array}{l}\text { Bohemia, } \\
\text { unknown } \\
\text { locality }\end{array}$ & $\begin{array}{l}\text { H } 13 \mathrm{AV}+2 \\
\text { AV }\end{array}$ & $\begin{array}{l}2 \mathrm{AV} \\
1520-1566\end{array}$ & $2 \mathrm{Misr}$ & after 1628 & $\begin{array}{l}\text { 1826/ Nálezy } \\
\text { III/1, no. } 3293\end{array}$ \\
\hline 18. & $\begin{array}{l}\text { Rychnov nad } \\
\text { Kněžnou }\end{array}$ & $\mathrm{H} \times \mathrm{AV}+\mathrm{AR}$ & $\mathrm{x}$ AV & - & after 1628 & $\begin{array}{l}\text { 1826/ Nálezy } \\
\text { III/1, no. } 3305\end{array}$ \\
\hline 19. & $\begin{array}{l}\text { Rakousy } \\
\text { (Semily distr.) }\end{array}$ & $\begin{array}{l}\mathrm{H} \times \mathrm{AV}(22 \mathrm{AV} \\
\text { described) }\end{array}$ & $1 \mathrm{AV}$ & - & after 1629 & $\begin{array}{l}\text { 1904/ Nálezy } \\
\text { III/1, no. } 3311\end{array}$ \\
\hline 20. & $\begin{array}{l}\text { Kojetín } \\
\text { (Přerov distr.) }\end{array}$ & H 283 AV & $\mathrm{x} A \mathrm{AV}$ & - & after 1635 & $\begin{array}{l}\text { 1865/ Nálezy } \\
\text { III/1, no. } 3362\end{array}$ \\
\hline 21. & $\begin{array}{l}\text { Vrchlabí } \\
\text { (Trutnov distr.) }\end{array}$ & $\mathrm{H} 45 \mathrm{AV}$ & $x \mathrm{AV}$ & - & after 1635 & $\begin{array}{l}\text { 1840/ Nálezy } \\
\text { III/1, no. } 3368\end{array}$ \\
\hline 22. & \begin{tabular}{|l} 
Korce \\
(Česká Lípa \\
distr.) \\
\end{tabular} & $\begin{array}{l}\text { H } 8 \text { AV + } 19 \\
\text { AR }\end{array}$ & $2 \mathrm{AV}$ & - & after 1636 & $\begin{array}{l}\text { 1915/ Nálezy } \\
\text { III/1, no. } 3371\end{array}$ \\
\hline 23. & \begin{tabular}{|l|} 
Daskabát \\
(Olomouc distr.)
\end{tabular} & H 9 AV & $x$ AV & - & after 1637 & $\begin{array}{l}\text { 1860/ Nálezy } \\
\text { III/1, no. } 3378 \\
\end{array}$ \\
\hline 24. & \begin{tabular}{|l} 
Vizovice (Zlín \\
distr.)
\end{tabular} & H $52 \mathrm{AV}$ & $5 \mathrm{AV}$ & - & after 1637 & $\begin{array}{l}\text { 1853/ Nálezy } \\
\text { III/1, no. } 3402\end{array}$ \\
\hline 25. & \begin{tabular}{|l|} 
Jindřichův \\
Hradec
\end{tabular} & H 177 AV & $10 \mathrm{AV}$ & - & after 1643 & $\begin{array}{l}\text { 1880/ Nálezy } \\
\text { III/1, no. } 3435\end{array}$ \\
\hline 26. & $\begin{array}{l}\text { Drhovy } \\
\text { (Příbram distr.) }\end{array}$ & $\begin{array}{l}\text { H } 3 \text { AV + } 18 \\
\text { AR }\end{array}$ & \begin{tabular}{|l}
$\mathrm{AV}$ \\
$1623-1640$
\end{tabular} & Misr & after 1644 & $\begin{array}{l}\text { 1955/ Nemeškal } \\
1958, \text { pp. 353- } \\
354\end{array}$ \\
\hline 27. & $\begin{array}{l}\text { Dobrotice } \\
\text { (Kroměříž } \\
\text { distr.) }\end{array}$ & $\begin{array}{l}\mathrm{H} 6 \mathrm{AV}+400 \\
\mathrm{AR}\end{array}$ & $\begin{array}{l}1 \mathrm{AV} \\
1520-1566\end{array}$ & - & after 1645 & $\begin{array}{l}\text {-/ Nálezy III/1, no. } \\
3441\end{array}$ \\
\hline 28. & $\begin{array}{l}\text { Ješetice, Radíč } \\
\text { Settlement } \\
\text { (Benešov distr.) }\end{array}$ & $\mathrm{H} 45 \mathrm{AV}+\mathrm{AR}$ & $1 \mathrm{AV}$ & - & after 1654 & $\begin{array}{l}\text { 1905/ Nálezy } \\
\text { III/1, no. } 3564\end{array}$ \\
\hline
\end{tabular}




\begin{tabular}{|c|c|c|c|c|c|c|}
\hline 29. & $\begin{array}{l}\text { Tichov (Zlín } \\
\text { distr.) }\end{array}$ & H $19 \mathrm{AV}$ & \begin{tabular}{|l}
$3 \mathrm{AV}$, \\
$1574-1595$, \\
$1595-1603$, \\
$1603-1617$ \\
\end{tabular} & $\begin{array}{l}\text { 1574-95/ Misr, } \\
\text { 1595-1603/ } \\
\text { Misr, 1603-17/ } \\
\text { Baghdad }\end{array}$ & after 1657 & $\begin{array}{l}\text { Před 1908/ Nálezy } \\
\text { III/1, no. } 2946\end{array}$ \\
\hline 30. & $\begin{array}{l}\text { Větrov } \\
\text { (Liberec distr.) }\end{array}$ & $\begin{array}{l}\text { H } 108 \mathrm{AV}+ \\
115 \mathrm{AR}\end{array}$ & \begin{tabular}{|l|}
$3 \mathrm{AV}$, \\
$1566-1574$, \\
$1574-1595$, \\
$1603-1617$ \\
\end{tabular} & $\begin{array}{l}1566-74 / \text { Misr, } \\
1574-95 / \text { Misr, } \\
1603-17 / \\
\text { Dimashq } \\
\end{array}$ & after 1660 & $\begin{array}{l}\text { 1907/ Nálezy } \\
\text { III/1, no. } 3583\end{array}$ \\
\hline 31. & \begin{tabular}{|l|} 
Petříkovice \\
(Trutnov distr.)
\end{tabular} & H $51 \mathrm{AV}$ & $1 \mathrm{AV}$ & - & after 1671 & $\begin{array}{l}\text { 1851/ Nálezy } \\
\text { III/1, no. } 3605\end{array}$ \\
\hline 32. & \begin{tabular}{|l|} 
Poběžovice \\
(Pardubice \\
distr.)
\end{tabular} & H $132 \mathrm{AR}$ & $\begin{array}{l}1 \mathrm{AR}, 1520- \\
1566\end{array}$ & Tchaynitcha & after 1673 & $\begin{array}{l}\text { 1930/ Nálezy } \\
\text { III/1, no. } 3610\end{array}$ \\
\hline 33. & \begin{tabular}{|l|} 
Lípov \\
(Hodonín distr.)
\end{tabular} & $\begin{array}{l}\text { H } 2 \text { AV + } 94 \\
\text { AR }\end{array}$ & $1 \mathrm{AV}$ & - & after 1680 & $\begin{array}{l}\text { 1843/ Nálezy } \\
\text { III/1, no. } 3624\end{array}$ \\
\hline 34. & \begin{tabular}{|l|} 
Zahnašovice \\
(Kroměříž \\
distr.)
\end{tabular} & $\begin{array}{l}\text { H } 9 \text { AV + } 206 \\
\text { AR }\end{array}$ & $1 \mathrm{AV}$ & - & after 1683 & \begin{tabular}{|l|}
$20^{\text {th }}$ century/ \\
Skutil and Malá \\
1958, p. 332
\end{tabular} \\
\hline 35. & \begin{tabular}{|l} 
Třešt' \\
(Jihlava distr.)
\end{tabular} & $\begin{array}{l}\mathrm{H} 672 \mathrm{AV}+11 \\
\mathrm{~kg} \text { of } \mathrm{AR}\end{array}$ & $\mathrm{x}$ AV & - & after 1688 & $\begin{array}{l}\text { 1915/ Nálezy } \\
\text { III/1, no. } 3637\end{array}$ \\
\hline 36. & Olomouc II & H 10 AR & $1 \mathrm{AR}$ & - & after 1694 & \begin{tabular}{|l|} 
before 1889/ \\
Nálezy III/1, no. \\
3646
\end{tabular} \\
\hline 37. & Praha-Suchdol & SF 1 AR & \begin{tabular}{|l}
$1 \mathrm{AR}, 1695-$ \\
1703
\end{tabular} & Qustantiniya & after 1703 & \begin{tabular}{|l|} 
1996/ Novák \\
1996, pp. 395- \\
398
\end{tabular} \\
\hline 38. & \begin{tabular}{|l|} 
Skuteč I \\
(Chrudim distr.)
\end{tabular} & $\mathrm{H} \times \mathrm{AV}$ & $\begin{array}{l}\text { x AV, 1520- } \\
1691 ?\end{array}$ & - & $17^{\text {th }}$ century & $\begin{array}{l}\text {-/ Nálezy III/1, no. } \\
3760\end{array}$ \\
\hline 39. & \begin{tabular}{|l|} 
Verdek \\
(Trutnov distr.)
\end{tabular} & $\begin{array}{l}\text { H } 5 \mathrm{AV}+60 \\
\text { AR }\end{array}$ & $?$ & - & $17^{\text {th }}$ century & \begin{tabular}{|l|} 
1931/ Nálezy \\
III/1, no. 3769 \\
\end{tabular} \\
\hline 40. & \begin{tabular}{|l|} 
Počátky \\
(Pelhřimov \\
distr.) \\
\end{tabular} & $\begin{array}{l}\text { H } 18 \mathrm{AV}+24 \\
\text { AR }\end{array}$ & $1 \mathrm{AV}$ & - & $\begin{array}{l}\text { about } 17^{\text {th }} \\
\text { century }\end{array}$ & $\begin{array}{l}\text { 1793/ Nálezy } \\
\text { III/1, no. } 4089\end{array}$ \\
\hline 41. & \begin{tabular}{|l|} 
Skuteč II. \\
(Chrudim distr.)
\end{tabular} & $\mathrm{H} \times \mathrm{AV}$ & $1 \mathrm{AV}$ & - & $\begin{array}{l}?\left(17^{\text {th }}\right. \\
\text { century })\end{array}$ & \begin{tabular}{|l|} 
1860-1870/ \\
Adámek 1900- \\
1901, p. 295; \\
Petrtyl 1955, p. \\
189
\end{tabular} \\
\hline 42. & \begin{tabular}{|l}
$\begin{array}{l}\text { Plešnice } \\
\text { (Plzeň distr.) }\end{array}$ \\
\end{tabular} & $\begin{array}{l}\text { H } 2500 \mathrm{AV}+ \\
\text { AR }\end{array}$ & $\mathrm{X}$ AV & - & after 1700 & \begin{tabular}{|l} 
1908/ Nálezy \\
III/1, no. 3664 \\
\end{tabular} \\
\hline 43. & Praha III & H $16 \mathrm{AV}$ & $3 \mathrm{AV}$ & - & after 1736 & \begin{tabular}{|l|} 
1860/ Nálezy \\
III/1, no. 3806
\end{tabular} \\
\hline 44. & Mladá Boleslav & H $53 \mathrm{AV}$ & $\mathrm{X}$ AV & - & after 1739 & \begin{tabular}{|l|} 
1832/ Nálezy \\
III/1, no. 3811 \\
\end{tabular} \\
\hline 45. & \begin{tabular}{|l|} 
Bystřice pod \\
Host. (Kroměříž \\
distr.) \\
\end{tabular} & $\mathrm{H} 9 \mathrm{AR}+1 \mathrm{AE}$ & $\begin{array}{l}1 \mathrm{AE}, 17^{\text {th }} \text { cent. } \\
(?)\end{array}$ & - & after 1777 & $\begin{array}{l}\text {-/ Nálezy III/1, no. } \\
3866\end{array}$ \\
\hline 46. & \begin{tabular}{|l} 
Budeč \\
(Kladno distr.)
\end{tabular} & $\mathrm{H} 4 \mathrm{AE}$ & $1 \mathrm{AE}, 1853$ & - & after 1920 & 1961/ unpublished \\
\hline
\end{tabular}

The newly documented Ottoman coins in the territory of Bohemia, Moravia, and Silesia between 1996 and 2018 show a rather different situation. On one side, the quantity of the registered material increased three times (117 pieces) compared to the previous period, and single finds totally dominate ( 6 hoards and 52 single finds with their terminus post quem up to 1800, and 40 single finds and 8 decorative jetons with their terminus 
post quem after 1800), gold coins represent the minority of the corpus (26 pieces), and quite a substantive quantity of coins (51 pieces) belong to issues produced after 1800 . Technically, the domination of single finds can be explained by the situation before 1989, when it was difficult to conceal a hoard, but individual coins could escape. Recently, it is possible to conceal anything, but curiosity and club prestige of the finders often dominate over possible (but in the decisive number of cases very unlikely) collision with the law.

All registered coins in Bohemia still confirm the theory concerning the territorially regularly dispersed finds in connection with the Thirty Years War, and individual pieces out of circulation lost in the non-Ottoman milieu. Historically later silver and copper coins can point to the period of the Napoleonic Wars or to the modern AustroHungarian period with its Balkan overlaps. In the Bohemian case, the copper coins evidently represent the secondary import. Decorative cloth jetons found in the territory of the Czech Republic can point to the local production for export (Jablonec), or to memorabilia imported from the Balkans.

The recent interpretation of the Moravian situation is still of a dual character: a) the territory to the south of the line Jihlava - Brno - Přerov - Vsetín was evidently in direct contact with the Ottoman element, and that is why the Ottoman gold appears there mainly individually, silver - similarly as in Slovakia - is connected with the Ottoman activities, and its mass or individual appearance seems to be historically more justified compared to Bohemia and the remaining parts of Moravia; b) the Moravian territory situated to the north of the mentioned line is again rather more characteristic by finds connected with the Thirty Years War.

From the historical-statistical point of view, it is possible to state that the coins found in the territory of the Czech Republic from 1996 to 2018 belong by their production dates to the period between 1360 and 1921. The earliest coin is represented by the $a k c ̧ e$ of Murad I (cat. no. 27), and the latest one by the 40 para of Mehmed VI (cat. no. 109). With their production dates of the $16^{\text {th }}$ and $17^{\text {th }}$ centuries, gold coins (with one exception for cat. no. 26, dating to 1818) cover the European thesaurization demand during the Thirty Years War (coins of the sultani type). Earlier Ottoman silver coins (with their production dates up to 1700) are mostly concentrated in the southern and central Moravian territory, which can be legitimately connected with the direct Ottoman activities up to the siege of Vienna (1683). The remaining silver coins - dominating in number - with their production dates around 1800 can be interpreted in connection with Napoleon's adventure in Egypt, later on with the Napoleonic Wars, and finally with the AustroHungarian period in the Balkans. In the case of copper coins, with the exception of the manghir from Loučka near Vsetín (cat. no. 75) - which is a relict of the attack in 1663 very likely - only the coins of Suleiman II (cat. nos. 79-89) can be classified in direct connection with the Turkish aggression and the siege of Vienna (1683).

Istanbul (Qustantiniya, Islambul on coins) evidently dominates among the Ottoman mints for the coins found from 1996 to 2018. Misr (i.e. Egypt, Cairo) is the second most frequent mint. In the case of gold coins, the following mints seem to be interesting: Halab (Aleppo, Syria, cat. no. 3), Jazair (Alger, cat. nos. 12, 21, 23) and Sidre Qapisi (Thessaloniki vilayet, continental Greece, cat. nos. 1, 4, 36). Among the silver issues, Edirne (cat. nos. 28, 30) and Nowar (Novo Brdo, Kosovo, cat. nos. 29, 32) attract special attention. Sometimes, relatively rare mints appear among the Ottoman earlier copper: Tarabulus Gharb (Tripoli, Libya, cat. no. 76), Brusa (noth-west Anatolia, cat. no. 75) and Saray (Sarajevo, Bosnia, cat. no. 89). In the case of gold issues and larger silver pieces, 
big central mints dominate (Istanbul, Misr), in the case of smaller and earlier silver denominations, as well as in the case of the copper coins, a larger territorial diversity with an inclination to the Balkans can be seen.

From a technical point of view, perforated pieces are worth noting (cat. nos. 16, 34, 37, $44,53,55-57,71,86,91,97-99,103,107)$. All decorative jetons have been pierced (cat. nos. 110-117). This kind of modification can give evidence of the secondary (decorative) use of the coins in their target (final) destination. The coins with pendant or traces of it (cat. nos. 26, 46, 47, 67), plus pieces modified for buttons (cat. nos. 66, 69, 72, 87, 90, 97) are of the same category. It is significant, that only four (among 34 pieces in total) of these decoratively modified coins were produced up until 1800. It is clear then, that the Ottoman coins found in the territory of the Czech Republic and produced before 1700 are more or less of the thesaurization character, and in other cases, their exotic aesthetic style (i.e., Arabic calligraphy) was given priority in a different historical era.

Forgeries of the Ottoman coins found in the territory of the Czech Republic can be seen as a special category. The silver gold plated forgery copying a gold coin from Vrchoslavice (Moravia, cat. no. 5), as well as the copper gold plated forgery from Louny předměstí (Bohemia, cat. no. 2), and also the forgery from Vysočina (cat. no. 17) evidently represent the increased contemporary demand for gold, and they are with the highest probability of a local (central European) provenance. ${ }^{11}$ Also the plated akçe from Olomouc (cat. no. 33) is interesting - it could be regarded as an authentic Ottoman forgery coming to the mentioned territory, which had been accidentally lost there. The copper copy from the Náchod region (cat. no. 78) very likely represents an amateurish European contemporary attempt of falsifying popular Ottoman larger silver denominations. The copper Ottoman forgery found near Třebíč (cat. no. 77) can more likely point to a possible real impact of the Ottoman milieu, as seen in the case of the published contemporary Turkish forgeries. ${ }^{12}$

\title{
A Catalogue of Unpublished or Recently Published Ottoman Coins Found between 1996 and 2018
}

The listing is based on metal and dynastic chronology with the reported locality and date of discovery in ascending order. Because of the fact that the majority of data has come anonymously from the web, the metrological figures are not complete in every instance, and the photos are sometimes beyond the publication limits.

\section{GOLD COINS}

\author{
Janovice u Kravař (Česká Lípa distr.), 2013: unpublished
}

Suleiman I (AH 926-974/ 1520-1566 CE), AV sultani, mint: Sidre Qapisi, AH 926/ 1520 CE - hoard of 9 gold (one Ottoman piece) and two silver coins (terminus post quem 1637). Obv.: in plain and pearl circles, six lines of Arabic inscriptions - sultān suleimān | bin salìm khān | 'azza nașruhu duriba | sidre qapisī fi | 926 | sana (Sultan Suleiman | son of Selim Khan | may [Allah] guarantee his victory, struck | Sidre Qapisi in | AH 926 | the year of), ornaments in the field, slightly ex-centric

11 For the Central European context in general, see Novák 2017.

12 Kabaklarli 1998. 
Rev.: in plain and pearl circles, three lines of Arabic inscriptions - ḍārib al-naḍ $\mid$ șāhib al-'izz wa al-nașr | fí al-barr wa al-bahr (person striking precious metal | lord of glory and victory | on land and on sea), ornaments in the field, slightly ex-centric

Lit.: Album 2011, p. 143, no. 1317; Artuk amd Artuk 1974, pp. 521-522, nos. 1566-1568 var.; Damali 2010/2, p. 698, no. 10-SD-A4a; Ghalib 1890, pp. 89-90, nos. 220-222 var.; Lane-Poole 1883, p. 74, nos. 185-187 var.; Mitchiner 1977, p. 206, no. 1254 var.; Østrup 1938, -; Pere 1968, p. 112, no. 187; Schaendlinger 1973, p. 96; Sultan 1977, p. 114, nos. pp. 1075-1076 var.

001 .

$$
3.521 \mathrm{~g} ; 20.6 / 20.2 \mathrm{~mm} ; 9 \mathrm{~h} \text {. }
$$

\title{
LOUNY-P̌̌EDMĚsTí (Louny distr.), 2016: Novák 2017
}

\section{A forgery copying the following prototype: Suleiman I (AH 926-974/ 1520-1566 CE),} AV sultani, mint: out of flan (fragment), [AH 926/ 1520 CE] - single find, a fragment of circa $50 \%$ of coin (plated, contemporary forgery with copper core), found together with Osman II (AH 1027-1031/ 1618-1622 CE), AR medini, mint: out of flan (Misr ?), [AH 1027/ 1618 CE].

Obv.: in plain and pearl circles, five lines of Arabic inscriptions - sulțān suleimān | [bin] salīm khān 'azza nașruhu | [ḍuriba ...] | fi | sana [926] (Sultan Suleiman | [son] of Selim Khan may [Allah] guarantee his victory, | [struck ...] | in | the year of [AH 926]), ornaments in the field, traces of irregular plating, broken flan.

Rev.: in plain and pearl circles, three lines of Arabic inscriptions - d̦ārib [al-naḍr] | șāhibib al-'izz [wa al-nașr] | fi al-barr wa al-bahr (person striking [precious metal] | lord of glory and [victory] | on land and on sea), ornaments in the field, traces of irregular plating, broken flan.

Lit.: Album 2011, for the type cf. p. 143, no. 1317; Artuk and Artuk 1974, for the obverse type cf. pp. 510-521, no. 1533 (Belgrad), no. 1534 (Bursa), no. 1564 (Srebrenica) and for the reverse type cf. pp. 505-524 no. 1517 (Qustantiniya), nos. 1523, 1525 (Amid), no. 1541 (Dimashq), no. 1548 (Mar’ash), no. 1556 (Misr), no. 1569 (Siruz), nos. 1572, 1573 (Zabid); Damali 2010/2, for the obverse type cf. pp. 502-503 (Amasiya), 526 (Baghdad), 540 (Belgrad), 544 (Bursa), 548 (Hanja), 568-569 (Edirne), 580 (Halab), 609, 613 (Qustantiniya), 661 (Mudawa), 698-700 (Sidre Qapisi), 713 (Siruz) and for the reverse type cf. pp. 507 (Amid), 525 (Baghdad), 578-579 (Halab), 608 (Qustantiniya), 663 (Mawsil), 684 (Ruha), 711(Siruz), 745 (Zabid) and parallelly for the obverse and reverse types cf. p. 564 no. 10-MS-A4a (Misr); Ghalib 1890, for the reverse type cf. p. 292 no. 2519 (Amasiya); Lane-Poole 1883, for the obverse type cf. pp. 71-74, no. 172 (Qustantiniya), no. 185 (Sidre Qapisi) and for the reverse type cf. pp. 78-81, no. 197 (Halab), no. 205 (Misr); Mitchiner 1977, for the obverse type cf. p. 206 no. 1252 (Qustantiniya) and parallelly for the obverse and reverse types cf. p. 206 no. 1253 (Misr), Østrup 1938, -; Pere 1968, for the obverse type cf. pp. 110-113 no. 159 (Baghdad), no. 162 (Belgrad), no. 163 (Bursa), no. 164 (Hanja), no. 170 (Edirne), no. 183 (Mudawa), no. 189 (Siruz) and for the reverse type cf. pp. 111-113 nos. 171, 173 (Halab), no. 191 (Tabriz), no. 194 (Zabid); Schaendlinger 1973, -; Sultan 1977, for the obverse type cf. no. 1076 (Sidre Qapisi); Zeno.ru, for the obverse type cf. nos. 83812, 15928 (Amasiya), no. 194158 (Belgrad), nos. 15730, 112366 (Bursa), no. 111748 (Halab), nos. 8970, 9641, 10325, 10653, 10654, 15934, 106054, 111793, 112367, 112787, 132489, 132492, 156220, 175258, 175903 (Qustantiniya), nos. 8450, 10349, 95332, 111777 (Sidre Qapisi), nos. 10320, 10930, 112371 (Siruz), nos. 114337, 189359 (Srebrenica) and for the reverse type cf. nos. 15926, 21720, 112661 (Amid), no. 15923 (Dimashq), nos. 15925, 112369, 112636 (Halab), no. 124159 (Mar'ash), nos. 10343, 132490 (Qustantiniya) and parallelly for the obverse and reverse types cf. no. 111753 (Qustantiniya).

002. $0.869 \mathrm{~g} ; 17.9 / 10.6 \mathrm{~mm}$ (about $1 \mathrm{~mm}$ thick); $9 \mathrm{~h}$, fragment (circa 50\%), broken flan, core shining out.

\section{Plzeñ Region, October 23, 2017: unpublished}

\author{
Suleiman I (AH 926-974/ 1520-1566 CE), AV sultani, mint: Halab, AH 926/ 1520 CE \\ - single find. \\ Obv.: in plain and pearl circles, six lines of Arabic inscriptions - sultān suleimān | bin salìm khān | 'azza \\ nașruhu ḍuriba | fì halab | sana | 926 (Sultan Suleiman | son of Selim Khan | may [Allah] guarantee his \\ victory, struck | in Aleppo | in the year of/ AH 926), ornaments in the field, slightly ex-centric. \\ Rev.: in plain and pearl circles, three lines of Arabic inscriptions - d̦ārib an-naḍ | șāhibib al-'izz wa an-nașr | fì \\ al-barr wa al-bahr (person striking precious metal | lord of glory and victory | on land and on sea), ornaments
}


in the field, slightly ex-centric.

Lit.: Album 2011, p. 143, no. 1317; Artuk and Artuk 1974, p. 514 no. 1543; Damali 2010/2, p. 579, no. 10-HPA2; Ghalib 1890, -; Lane-Poole 1883, p. 78, no. 198; Mitchiner 1977, -; Østrup 1938, p. 293, no. 2520; Pere 1968, p. 111, no. 172; Schaendlinger 1973, p. 96; Sultan 1977, -.

Lovecpokladu.cz (available at: https://www.lovecpokladu.cz/artefakty/nalez/prosim-o-urceni-153853/, October 2017).

003. $3.5 \mathrm{~g} ; 19.4 \mathrm{~mm} ; 4 \mathrm{~h}$.

Horní RÁPOTICE (Pelhřimov distr.), 2015: unpublished

Suleiman I (AH 926-974/ 1520-1566 CE), AV sultani, mint: Sidre Qapisi, AH 926/ 1520 CE - hoard (Thirty Years War) together with Murad III (AH 982-1003/ 1574-1595 CE), AV sultani, mint: Jazair, AH 982/ 1574 CE and 2 pieces of Murad III (AH 982-1003/ 1574-1595 CE), AV sultani, mint: Misr, AH 982/ 1574 CE, plus 337 silver and gold European coins. Obv.: in plain and pearl circles, six lines of Arabic inscriptions - sulțān suleimān | bin salīm khān | 'azza nașruhu duriba | sidre qapisī fi sana | 926 (Sultan Suleiman | son of Selim Khan | may [Allah] guarantee his victory, struck | Sidre Qapisi in the year of | AH 926), ornaments in the field, slightly ex-centric

Rev.: in plain and pearl circles, three lines of Arabic inscriptions - d̦ărib al-naḍ $\mid$ șāhib al-'izz wa al-nașr | fi al-barr wa al-bahr (person striking precious metal | lord of glory and victory | on land and on sea), ornaments in the field, slightly ex-centric

Lit.: Album 2011, p. 143, no. 1317; Artuk - Artuk 1974, pp. 521-522, nos. 1566-1568 var.; Damali 2010/2, p. 700, no. 10-SD-A4f var.; Ghalib 1890, pp. 89-90, nos. 220-222 var.; Lane-Poole 1883, p. 74, nos. 185-187 var.; Mitchiner 1977, p. 206, no. 1254 var.; Østrup 1938, -, Pere 1968, p. 112, no. 187; Schaendlinger 1973, p. 96; Sultan 1977, p. 114, nos. 1075-1076 var.

004. $3.449 \mathrm{~g} ; 19.3 / 19.0 \mathrm{~mm} ; 1 \mathrm{~h}$.

Vrchoslavice (Prostějov distr.), 2010: Novák and Videman 2011

A forgery copying the following prototype: Selim II (AH 974-982/ 1566-1574 CE), AV sultani, mint: out of flan, AH [9]74/ 1566 CE - single find, fragment, contemporary forgery (gold plated silver core).

Obv.: in plain and pearl circles, five lines of Arabic inscriptions - sultān [salīm bin] | sultān [suleimān khān] | 'azza nașruhu ... | ... sana/ [9]74 (Sultan [Selim, son] | of Sultan [Suleiman Khan] | may [Allah] guarantee his victory ... | in the year of | AH [9]74), ornaments in the field.

Rev.: in plain and pearl circles, three lines of Arabic inscriptions - [d̄ārib al-nadrr] | șāhib al-'izz [wa al-nașr] | fì al-barr wa al-bahr ([person] striking precious metal | lord of glory [and victory] | on land and on sea), ornaments in the field, traces of irregular plating (bubles).

Lit.: Album 1998, for the type cf. p. 66, no. 1324; Artuk and Artuk 1974, for the type cf. pp. 531, no. 1580 (Amid), 534, no. 1591 (Dimashq), 535, no. 1592 (Halab); Ghalib 1890, for the type cf. pp. 124, nos. 322-323 (Amid), 125, no. 326 (Halab), 126, no. 328 (Dimashq); Lane-Poole 1883, for the type cf. p. 87, nos. 226228 (Halab); Mitchiner 1977, -; Østrup 1938, -; Pere 1968, for the type cf. p. 120 no. 227 (Amid), no. 234 (Dimashq), no. 235 (Halab); Schaendlinger 1973, -; Sultan 1977, - .

005. $1.393 \mathrm{~g} ; 20.5 / 10.5 \mathrm{~mm}$ (about 0.9-1.1 mm thick); $4 \mathrm{~h}$, fragment (circa 50\%), shining silver core.

DoвromĚřice (Louny distr.), 2013: unpublished

Selim II (AH 974-982/ 1566-1574 CE), AV sultani, mint: Misr, AH 974/ 1566 CE hoard (Thirty Years War) together with Murad III (AH 982-1003/ 1574-1595 CE), AV sultani, mint: Misr, AH 982/ 1574 CE and four still unattributed gold European coins, plus at least six silver coins of the thaler type, very likely of the $17^{\text {th }}$ century.

Obv.: in plain and pearl circles, five lines of Arabic inscriptions - sulțān salìm | bin sulțān suleimān khān | 'azza nașruhu duriba fi | mișr sana | 974 (Sultan Selim | son of Sultan Suleiman Khan | may [Allah] guarantee his victory, struck in | Egypt the year of | AH 974), ornaments in the field, slightly ex-centric 
Rev.: in plain and pearl circles, three lines of Arabic inscriptions - d̦ārib al-naḍ | șāhib al-'izz wa al-nașr | fì al-barr wa al-bahr (person striking precious metal | lord of glory and victory | on land and on sea), ornaments in the field, slightly ex-centric

Lit.: Album 2011, p. 143, no. 1324; Artuk and Artuk 1974, p. 535, no. 1593; Damali 2011/3, p. 867, no. 11-MSA1b; Ghalib 1890, p. 128, no. 335; Lane-Poole 1883, p. 89, no. 231; Mitchiner 1977, p. 206, no. 1257 var.; Østrup 1938, p. 294, no. 2534 var. of the reverse legend; Pere 1968, p. 121 no. 239 var.; Schaendlinger 1973, p. 101; Sultan 1977, p. 123, no. 1178, Tab. 91 var.

006. $3.443 \mathrm{~g} ; 20.0 / 20.1 \mathrm{~mm} ; 3 \mathrm{~h}$.

Prague-Castle, 2006: Frolík and Novák 2007

Murad III (AH 982-1003/ 1574-1595 CE), AV sultani, mint: Misr, AH 982/ 1574 CE - single find.

Obv.: in plain and pearl circles, five lines of Arabic inscriptions - sulțān murād bin $\mid$ salìm khān 'azza $\mid$ nașruhu duriba fi | mișr sana | 982 (Sultan Murad, son | of Selim Khan, may [Allah] guarantee | his victory, struck in | Egypt the year of | AH 982), ornaments in the field, die larger than flan.

Rev.: in plain and pearl circles, four lines of Arabic inscriptions - sultān al-barrayn | wa khāqān al-bahrayn | al-sulțān bin | al-sulțān (sultan of two continents - Europe and Asia Minor | lord of two seas - Aegean Sea and Black Sea | sultan, son | of sultan), ornaments in the field, slightly ex-centric

Lit.: Album 2011, p. 143, no. 1332.1; Artuk and Artuk 1974, p. 549, no. 1625; Ghalib 1890, p. 147, nos. 388-389; Lane-Poole 1883, p. 96, nos. 252-254; Mitchiner 1977, p. 207, no. 1259 var.; Østrup 1938, p. 295, no. 2540; Pere 1968, p. 127, no. 274, Tab. 17 var.; Schaendlinger 1973, p. 103, no. 32, Tab. 2 var.; Sultan 1977, p. 132, nos. 1200-1201, Tab. 93 var.

007.

$3.451 \mathrm{~g} ; 22.1 / 21.5 \mathrm{~mm} ; 6 \mathrm{~h}$.

Votice (Benešov distr.), 2010: Novák and Procházka 2010

Murad III (AH 982-1003/ 1574-1595 CE), AV sultani, mint: Misr, [AH 982/ 1574 CE] - single find.

Obv.: in plain and pearl circles, five lines of Arabic inscriptions - sulțān murād bin $\mid$ salīm khān 'azza | nașruhu duriba fi | mișr sana | [982] (Sultan Murad, son | of Selim Khan, may [Allah] guarantee | his victory, struck in | Egypt the year of | [AH 982]), ornaments in the field, slightly ex-centric

Rev.: in plain and pearl circles, three lines of Arabic inscriptions - dārib al-naḍ | șāhib al-'izz wa al-naṣr | fì al-barr wa al-bahr (person striking precious metal | lord of glory and victory | on land and on sea), ornaments in the field, die larger than flan.

Lit.: Album 2011, p. 143, no. 1332.1; Artuk and Artuk 1974, p. 548, no. 1624; Ghalib 1890, p. 147, no. 388; Lane-Poole 1883, -; Mitchiner 1977, -; Østrup 1938, p. 295, no. 2541; Pere 1968, p. 127, no. 273 var.; Schaendlinger 1973, p. 103, Sultan 1977, p. 132, no. 1200 var.

008. $\quad 3.390 \mathrm{~g} ; 19.2 / 19.1 \mathrm{~mm} ; 2 \mathrm{~h}$, bent and worn flan in the margin.

TvRDONICE (Břeclav distr.), 2010: Novák 2014

\begin{abstract}
Murad III (AH 982-1003/ 1574-1595 CE), AV sultani, mint: Misr, [AH 982/ 1574 CE] - single find.

Obv.: in plain and pearl circles, five lines of Arabic inscriptions - sultān murād bin $\mid$ salìm khān 'azza $\mid$ nașruhu duriba fi $\mid$ mișr sana | [982] (Sultan Murad, son | of Selim Khan, may [Allah] guarantee | his victory, struck in | Egypt the year of | [AH 982]), ornaments in the field, slightly ex-centric

Rev.: in plain and pearl circles, three lines of Arabic inscriptions - dārib al-nadr $\mid$ șāhib al-'izz wa al-nașr | fi al-barr wa al-bahr (person striking precious metal | lord of glory and victory | on land and on sea), ornaments in the field, die larger than flan.

Lit.: Album 2011, p. 143, no. 1332.1; Artuk and Artuk 1974, p. 548, no. 1624; Ghalib 1890, p. 147, no. 388; Lane-Poole 1883, -; Mitchiner 1977, -; Østrup 1938, p. 295, no. 2541; Pere 1968, p. 127, no. 273 var.; Schaendlinger 1973, p. 103; Sultan 1977, p. 132, no. 1200 var.
\end{abstract}

009. 3.51g; 19.1/19.2 mm; $6 \mathrm{~h}$, bent and worn flan in the margin, traces of complex bending. 
BOHEMIA, 2011: unpublished

\section{Murad III (AH 982-1003/ 1574-1595 CE), AV sultani, mint: Misr, AH 982/ 1574 CE}

- single find.

Obv.: in plain and pearl circles, five lines of Arabic inscriptions - sultān murād bin $\mid$ salìm khān 'azza $\mid$ nașruhu duriba fi | mișr sana | 982 (Sultan Murad, son | of Selim Khan, may [Allah] guarantee | his victory, struck in | Egypt the year of | AH 982), ornaments in the field, slightly ex-centric

Rev.: in plain and pearl circles, three lines of Arabic inscriptions - dārib al-nad̆r | șāhib al-'izz wa al-nașr | fì al-barr wa al-bahr (person striking precious metal | lord of glory and victory | on land and on sea), ornaments in the field, slightly ex-centric

Lit.: Album 2011, p. 143, no. 1332.2; Artuk and Artuk 1974, p. 548, no. 1624; Damali 2011/3, p. 1027, no. 12-MS-A1b; Ghalib 1890, p. 147, no. 389; Lane-Poole 1883, p. 96, nos. 252-254; Mitchiner 1977, p. 207, no. 1259 var.; Østrup 1938, p. 295, no. 2541; Pere 1968, p. 127, no. 273; Schaendlinger 1973, p. 103; Sultan 1977, p. 132 , no. $1200-1201$.

Detektorweb.cz (2011).

010. Metrological data are not known (19/20 $\mathrm{mm}$ based on the photo with scale).

DoвROMĚŘICE (Louny distr.), 2013: unpublished

Murad III (AH 982-1003/ 1574-1595 CE), AV sultani, mint: Misr, AH 982/ 1574 CE - hoard (Thirty Years War) together with Selim II (AH 974-982/ 1566-1574 CE), AV sultani, mint: Misr, AH 974/ $1566 \mathrm{CE}$ and four still unattributed gold European coins, plus at least six silver coins of the thaler type, very likely of the $17^{\text {th }}$ century.

Obv.: in plain and pearl circles, five lines of Arabic inscriptions - sulțān murād bin $\mid$ salìm khān 'azza $\mid$ nașruhu duriba fi | mișr sana | 982 (Sultan Murad, son | of Selim Khan, may [Allah] guarantee | his victory, struck in | Egypt the year of/ AH 982), ornaments in the field, slightly ex-centric

Rev.: in plain and pearl circles, four lines of Arabic inscriptions - sultān al-barrayn | wa chāqān al-bahrayn | al-sultān bin | al-sulțān (sultan of two continents - Europe and Asia Minor | lord of two seas - Aegean Sea and Black Sea | sultan, son | of sultan), ornaments in the field, slightly ex-centric

Lit.: Album 2011, p. 143, no. 1332.2; Artuk and Artuk 1974, p. 549, no. 1625; Damali 2011/3, p. 1028, no. 12MS-A2; Ghalib 1890, p. 147, no. 389; Lane-Poole 1883, p. 96, nos. 252-254; Mitchiner 1977, p. 207, no. 1259 var.; Østrup 1938, p. 295, no. 2540 var.; Pere 1968, p. 127, no. 274 var.; Schaendlinger 1973, p. 103, no. 32/ Tab. 2 var.; Sultan 1977, p. 132, nos. 1200-1201, Tab. 93 var.

011. $\quad 3.445 \mathrm{~g} ; 19.9 / 20.1 \mathrm{~mm} ; 5 \mathrm{~h}$.

Horní RÁPOtice (Pelhřimov distr.), 2015: unpublished

Murad III (AH 982-1003/ 1574-1595 CE), AV sultani, mint: Jazair, AH 982/ 1574 CE and 2 pieces of Murad III (AH 982-1003/ 1574-1595 CE), AV sultani, mint: Misr, AH 982/ 1574 CE - hoard (Thirty Years War) together with Suleiman I (AH 926-974/ 1520-1566 CE), AV sultani, mint: Sidre Qapisi, AH 926/ 1520 CE, plus 337 silver and gold European coins.

Mint: Jazair, AV sultani, AH 982/ 1574 CE.

Obv.: in plain and pearl circles, five lines of Arabic inscriptions - sulțān murād | bin salīm khān 'azza | nașruhu duriba fi | jazā'ir sana | 982 (Sultan Murad, son | of Selim Khan, may [Allah] guarantee | his victory, struck in | Alger the year of | AH 982), ornaments in the field, slightly ex-centric

Rev.: in plain and pearl circles, three lines of Arabic inscriptions ḍarib al-naḍr | șāhibib al-'izz wa al-nașr | fĩ albarr wa al-bahr (person striking precious metal | lord of glory and victory | on land and on sea), ornaments in the field.

Lit.: Album 2011, p. 143, no. 1332.1; Artuk and Artuk 1974, p. 546, no. 1615 var.; Damali 2011/3, p. 969, no. 12-CZ-A1b; Ghalib 1890, p. 148, no. 392; Lane-Poole 1883, -; Østrup 1938, p. 295, no. 2544; Pere 1968, p. 127, no. 264; Schaendlinger 1973, p. 102; Sultan 1977, -.

012. $3.458 \mathrm{~g} ; 18.0 / 18.2 \mathrm{~mm} ; 5 \mathrm{~h}$, pierced by a sharp instrument. 
Mint: Misr, AV sultani, AH 982/ 1574 CE

Obv.: in plain and pearl circles, five lines of Arabic inscriptions - sulțān murād bin $\mid$ salīm khān 'azza | naṣruhu duriba fi | mișr sana | 982 (Sultan Murad, son | of Selim Khan, may [Allah] guarantee | his victory, struck in | Egypt the year of | AH 982), ornaments in the field.

Rev.: in plain and pearl circles, three lines of Arabic inscriptions - dārib al-naḍr | șāhib al-'izz wa al-nașr | fi al-barr wa al-bahr (person striking precious metal | lord of glory and victory | on land and on sea), ornaments in the field. Lit.: Album 2011, p. 143, no. 1332.1; Artuk and Artuk 1974, p. 548, no. 1624; Damali 2011/3, p. 1027, no. 12-MS-A1c; Ghalib 1890, p. 147, no. 388; Lane-Poole 1883, -; Mitchiner 1977, -; Østrup 1938, p. 295, no. 2541; Pere 1968, p. 127, no. 273; Schaendlinger 1973, p. 103; Sultan 1977, p. 132, no. 1200.

013. $\quad 3.463 \mathrm{~g} ; 18.3 / 18.5 \mathrm{~mm} ; 2 \mathrm{~h}$.

Mint: Misr, AV sultani, AH 982/ 1574 CE

Obv.: in plain and pearl circles, five lines of Arabic inscriptions - sulțān murād bin $\mid$ salīm khān 'azza $\mid$ nașruhu duriba fi | mișr sana | 982 (Sultan Murad, son | of Selim Khan, may [Allah] guarantee | his victory, struck in | Egypt the year of | AH 982), ornaments in the field, slightly ex-centric

Rev.: in plain and pearl circles, four lines of Arabic inscriptions - sulțān al-barrayn | wa chāqān al-bahrayn | al-sulțān bin | al-sulțān (sultan of two continents - Europe and Asia Minor | lord of two seas - Aegean Sea and Black Sea | sultan, son | of sultan), ornaments in the field, slightly ex-centric

Lit.: Album 2011, p. 143, no. 1332.2; Artuk and Artuk 1974, p. 549, no. 1625; Damali 2011/3, p. 1028, no. 12-MSA2; Ghalib 1890, p. 147, no. 389; Lane-Poole 1883, p. 96, nos. 252-254; Mitchiner 1977, p. 207, no. 1259; Østrup 1938, p.295, no. 2540; Pere 1968, p. 127, no. 274; Schaendlinger 1973, p. 103; Sultan 1977, p. 132, no. 1201.

014. $\quad 3.430 \mathrm{~g} ; 20.1 / 20.0 \mathrm{~mm} ; 4 \mathrm{~h}$.

BOHEMIA, 2017: unpublished

\section{Murad III (AH 982-1003/ 1574-1595 CE), AV sultani, mint: Misr, AH 982/ 1574 CE} - single find.

Obv.: in plain and pearl circles, five lines of Arabic inscriptions - sultān murād bin $\mid$ salīm khān 'azza | nașruhu duriba fi | mișr sana/ 982 (Sultan Murad, son | of Selim Khan, may [Allah] guarantee | his victory, struck in | Egypt the year of | AH 982), ornaments in the field, slightly ex-centric

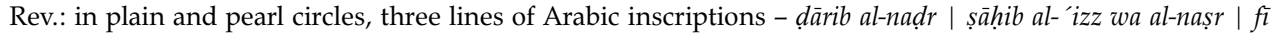
al-barr wa al-bahr (person striking precious metal | lord of glory and victory | on land and on sea), ornaments in the field, slightly ex-centric

Lit.: Album 2011, p. 143, no. 1332.2; Artuk and Artuk 1974, p. 548, no. 1624; Damali 2011/3, p. 1027, no. 12-MS-A1b; Ghalib 1890, p. 147, no. 389; Lane-Poole 1883, p. 96, nos. 252-254; Mitchiner 1977, p. 207, no. 1259 var.; Østrup 1938, p. 295, no. 2541; Pere 1968, p. 127, no. 273; Schaendlinger 1973, p. 103; Sultan 1977, p. 132 , nos. $1200-1201$.

015. Metrological data are not known.

\section{Central Bohemian Region, April 4, 2018: unpublished}

\section{Murad III (AH 982-1003/ 1574-1595 CE), AV sultani, mint: Misr, AH 982/ AD 1574}

- single find.

Obv.: in plain and pearl circles, five lines of Arabic inscriptions - sulțān murād bin $\mid$ salīm khān 'azza $\mid$ nașruhu duriba fi | mișr sana | 982 (Sultan Murad, son | of Selim Khan, may [Allah] guarantee | his victory, struck in | Egypt the year of | AH 982), ornaments in the field, slightly ex-centric

Rev.: in plain and pearl circles, four lines of Arabic inscriptions - sulțān al-barrayn | wa chāqān al-bahrayn | al-sultān bin | al-sulțān (sultan of two continents - Europe and Asia Minor | lord of two seas - Aegean Sea and Black Sea | sultan, son | of sultan), ornaments in the field, slightly ex-centric

Lit.: Album 2011, p. 143, no. 1332.2; Artuk and Artuk 1974, p. 549, no. 1625; Damali 2011/3, p. 1028, no. 12MS-A2; Ghalib 1890, p. 147, no. 389; Lane-Poole 1883, p. 96, nos. 252-254; Mitchiner 1977, p. 207, no. 1259 var.; Østrup 1938, 295, no. 2540 var.; Pere 1968, p. 127, no. 274; Schaendlinger 1973, p. 103, no. 32/ Tab. 2 var.; Sultan 1977, p. 132, nos. 1200-1201, Tab. 93 var.

Lovecpokladu.cz, no. 5819 (available at: https://www.lovecpokladu.cz/artefakty/nalez/prvni-zlatak-167300/, 2018).

016. $3.35 \mathrm{~g} ; 21 \mathrm{~mm}$, perforation, broken and bent flan. 

CE), AV sultani, mint: Misr, AH 982/ 1574 CE - single find, fragment (circa 50\%), a contemporary forgery.

Obv.: in plain and pearl circles, five lines of Arabic inscriptions - sulțān murād bin | salīm khān 'azza | naṣruhu duriba fi | mișr sana | 982 (Sultan Murad, son | of Selim Khan, may [Allah] guarantee | his victory, struck in | Egypt the year of | AH 982), ornaments in the field, slightly ex-centric

Rev.: in plain and pearl circles, four lines of Arabic inscriptions - sultān al-barrayn | wa chāqān al-bahrayn | al-sultān bin | al-sultān (sultan of two continents - Europe and Asia Minor | lord of two seas - Aegean Sea and Black Sea | sultan, son | of sultan), ornaments in the field, slightly ex-centric

Lit.: Album 2011, p. 143, no. 1332.2; Artuk and Artuk 1974, p. 549, no. 1625; Damali 2011/3, p. 1028, no. 12MS-A2; Ghalib 1890, p. 147, no. 389; Lane-Poole 1883, p. 96, nos. 252-254; Mitchiner 1977, p. 207, no. 1259 var.; Østrup 1938, p. 295, no. 2540 var.; Pere 1968, p. 127, no. 274; Schaendlinger 1973, p. 103, no. 32/ Tab. 2 var.; Sultan 1977, p. 132, nos. 1200-1201, Tab. 93 var.

Lovecpokladu.cz (available at: https://www.lovecpokladu.cz/artefakty/nalez/neznama-mince-185801/, 2018).

017. Metrological data are not known.

KRÁLíKy (Ústí nad Orlicí distr.), 2018: unpublished

Murad III (AH 982-1003/ 1574-1595 CE), AV sultani, mint: Misr, [AH 982/ 1574 CE] - hoard (Trirty Years War) together with Ahmed I (AH 1012-1026/ 1603-1617 CE), AV sultani, mint: Misr, AH 1012/ 1603 CE, plus 58 gold European coins (Netherlands, Hungary, Poland, Bohemia), terminus post quem beginning of the 1630s.

Obv.: in plain and pearl circles, five lines of Arabic inscriptions - sulțān murād bin | salīm khān 'azza | nașruhu duriba fi | missr sana | 982 (Sultan Murad, son | of Selim Khan, may [Allah] guarantee | his victory, struck in | Egypt the year | AH 982), ornaments in the field, slightly ex-centric

Rev.: in plain and pearl circles, three lines of Arabic inscriptions - d̦ārib al-nadr $\mid$ șāhib al-'izz wa al-nașr | fi al-barr wa al-bahr (person striking precious metal | lord of glory and victory | on land and on sea), ornaments in the field, slightly ex-centric

Lit.: Album 2011, p. 143, no. 1332.2; Artuk and Artuk 1974, p. 548, no. 1624; Damali 2011/3, p. 1027, no. 12-MS-A1b; Ghalib 1890, p. 147, no. 389; Lane-Poole 1883, p. 96, nos. 252-254; Mitchiner 1977, p. 207, no. 1259 var.; Østrup 1938, p. 295, no. 2541; Pere 1968, p. 127, no. 273; Schaendlinger 1973, p. 103; Sultan 1977, p. 132 , nos. $1200-1201$.

018. $\quad 3.474 \mathrm{~g} ; 19.7 \mathrm{~mm}$.

BOHEMIA, 2011: unpublished

Ahmed I (AH 1012-1026/ 1603-1617 CE), AV sultani, mint: Misr, AH 1012/ 1603 CE - single find.

Obv.: in plain and pearl circles, five lines of Arabic inscriptions - sulțān ahmad bin | muhammad khān 'azza | nașruhu duriba fi | mișr sana | 1012 (Sultan Ahmed, son | of Mehmed Khan, may [Allah] guarantee | his victory, struck in | Egypt the year of | AH 1012), ornaments in the field, slightly ex-centric

Rev.: in plain and pearl circles, four lines of Arabic inscriptions - sulțān al-barrayn | wa chāqān al-bahrayn | al-sulțān bin | al-sulțān (sultan of two continents - Europe and Asia Minor | lord of two seas - Aegean Sea and Black Sea | sultan, son | of sultan), ornaments in the field, slightly ex-centric

Lit.: Album 2011, p. 144, no. 1347.2; Artuk and Artuk 1974, p. 572, no. 1670; Damali 2011/4, p. 1385, no. 14-MS-A1; Ghalib 1890, p. 175, no. 455; Lane-Poole 1883, p. 110, nos. 259-293; Mitchiner 1977, p. 207, no. 1268; Østrup 1938, -; Pere 1968, p. 141, no. 357; Schaendlinger 1973, p. 107; Sultan 1977, -.

Detektorweb.cz (2011).

019. Metrological data are not known, not fully struck. 


\title{
Ahmed I (AH 1012-1026/ 1603-1617 CE), AV sultani, mint: Qustantiniya, AH 1012/ 1603 CE - single find.
}

Obv.: in plain and pearl circles, five lines of Arabic inscriptions - sultān ahmad | bin muhammad khān | 'azza nașruhu duriba fi | qus an ininya sana | 1012 (Sultan Ahmed | son of Mehmed Khan | may [Allah] guarantee his victory, struck in | Qustantiniya the year of | AH 1012), ornaments in the field, slightly ex-centric

Rev.: in plain and pearl circles, three lines of Arabic inscriptions - d̦ārib al-naḍr | șāhibib al- 'izz wa al-naṣr | fì al-barr wa al-bahr (person striking precious metal | lord of glory and victory | on land and on sea), ornaments in the field, slightly ex-centric

Lit.: Album 2011, p. 144, no. 1347.1; Artuk and Artuk 1974, p. 568, no. 1658; Damali 2011/4, p. 1375, no. 14-K-A1b; Ghalib 1890, p. 169, no. 433; Lane-Poole 1883, p. 106, nos. 280-281; Mitchiner 1977, -; Østrup 1938, p. 297, no. 2557; Pere 1968, p. 141, no. 355; Schaendlinger 1973, p. 107; Sultan 1977, -.

020. $3.40 \mathrm{~g} ; 20 \mathrm{~mm}$.

Mladá Boleslav, 2015: unpublished

\begin{abstract}
Ahmed I (AH 1012-1026/ 1603-1617 CE), AV sultani, mint: Jazair, [AH 1012/ 1603 CE] - single find.

Obv.: in plain and pearl circles, five lines of Arabic inscriptions - sulțān ahmad | bin muhammad khān 'azza |

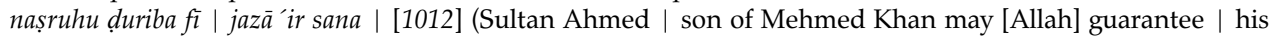
victory, struck in | Alger the year of | [AH 1012]), ornaments in the field, slightly ex-centric

Rev.: in plain and pearl circles, three lines of Arabic inscriptions - d̦ărib al-nadr $\mid$ șāhib al-'izz wa al-nașr | fi al-barr wa al-bahr (person striking precious metal | lord of glory and victory | on land and on sea), ornaments in the field, slightly ex-centric

Lit.: Album 2011, p. 144, no. 1347.1; Artuk and Artuk 1974, -; Damali 2011/4, p. 1346, no. 14-CZ-A1b; Ghalib 1890, p. 177, no. 464; Lane-Poole 1883, p. 113, no. 304; Mitchiner 1977, -; Østrup 1938, -; Pere 1968, p. 140, no. 348; Schaendlinger 1973, p. 106; Sultan 1977, p. 155, no. 1449.
\end{abstract}

021. Metrological data are not known (21/20 mm based on the photo with scale).

DobrušKa (Rychnov nad Kněžnou distr.), 2016: unpublished

\begin{abstract}
Ahmed I (AH 1012-1026/ 1603-1617 CE), AV sultani, mint: Qustantiniya, [AH 1012/ $1603 \mathrm{CE}$ - single find.

Obv.: in plain and pearl circles, five lines of Arabic inscriptions - sultān ahmad | bin muhammad khān | 'azza nașruhu duriba fi | qus an inīya [sana | 1012] (Sultan Ahmed | son of Mehmed Khan | may [Allah] guarantee his victory, struck in | Qustantiniya [the year of | AH 1012]), ornaments in the field, slightly ex-centric

Rev.: in plain and pearl circles, three lines of Arabic inscriptions - d̦ārib al-naḍ | șāhib al-'izz wa al-nașr | fì al-barr wa al-bahr (person striking precious metal | lord of glory and victory | on land and on sea), ornaments in the field, slightly ex-centric

Lit.: Album 2011, p. 144, no. 1347.1; Artuk and Artuk 1974, p. 568, no. 1658; Damali 2011/4, p. 1375, no. 14-K-A1b; Ghalib 1890, p. 169, no. 433; Lane-Poole 1883, p. 106, nos. 280-281; Mitchiner 1977, -; Østrup 1938, p. 297, no. 2557; Pere 1968, p. 141, no. 355; Schaendlinger 1973, p. 107; Sultan 1977, -.
\end{abstract}

022.

$3.449 \mathrm{~g} ; 19.5 / 20.1 \mathrm{~mm} ; 1 \mathrm{~h}$.

\section{Central Bohemian Region, September 24, 2016: unpublished}

\footnotetext{
Ahmed I (AH 1012-1026/ 1603-1617 CE), AV sultani, mint: Jazair, AH 1012/ 1603 CE - single find.

Obv.: in plain and pearl circles, five lines of Arabic inscriptions - sultān ahmad | bin muhammad khān 'azza | nașruhu duriba fí | jazā'ir sana | [1012] (Sultan Ahmed | son of Mehmed Khan may [Allah] guarantee | his victory, struck in | Alger the year of | [AH 1012]), ornaments in the field, slightly ex-centric
} 
Rev.: in plain and pearl circles, three lines of Arabic inscriptions - d̦ārib al-naḍ | șāhib al-'izz wa al-nașr | fì al-barr wa al-bahr (person striking precious metal | lord of glory and victory | on land and on sea), ornaments in the field, slightly ex-centric

Lit.: Album 2011, p. 144, no. 1347.1; Artuk and Artuk 1974, -; Damali 2011/4, p .1346, no. 14-CZ-A1b; Ghalib 1890, p. 177, no. 464; Lane-Poole 1883, p. 113, no. 304; Mitchiner 1977, -; Østrup 1938, -; Pere 1968, p. 140, no. 352; Schaendlinger 1973, p. 106; Sultan 1977, p. 155, no. 1449.

Lovecpokladu.cz (available at: https://www.lovecpokladu.cz/artefakty/nalez/mince-118950/, 2016).

023. $4.00 \mathrm{~g} ; 20 \mathrm{~mm}$, bent flan.

KRáLÍKY (Ústí nad Orlicí distr.), 2018: unpublished

Ahmed I (AH 1012-1026/ 1603-1617 CE), AV sultani, mint: Misr, AH 1012/ 1603 CE - hoard (Thirty Years War) together with Murad III (AH 982-1003/ 1574-1595 CE), AV sultani, mint: Misr, [AH 982/ 1574 CE], plus 58 gold European coins (Netherlands, Hungary, Poland, Bohemia), terminus post quem beginning of the 1630s.

Obv.: in plain and pearl circles, five lines of Arabic inscriptions - sultān ahmad bin | muhammad khän 'azza | nașruhu duriba fi | missr sana | 1012 (Sultan Ahmed, son | of Mehmed Khan, may [Allah] guarantee | his victory, struck in | Egypt the year of | AH 1012), ornaments in the field, slightly ex-centric

Rev.: in plain and pearl circles, four lines of Arabic inscriptions - sulțān al-barrayn | wa chāqān al-bahrayn | al-sultāan bin | al-sultān (sultan of two continents - Europe and Asia Minor | lord of two seas - Aegean Sea and Black Sea | sultan, son | of sultan), ornaments in the field, slightly ex-centric

Lit.: Album 2011, p. 144, no. 1347.2; Artuk and Artuk 1974, p. 572, no. 1670; Damali 2011/4, p. 1385, no. 14-MS-A1; Ghalib 1890, p. 175, no. 455; Lane-Poole 1883, p. 110, nos. 259-293; Mitchiner 1977, p. 207, no. 1268; Østrup 1938, -; Pere 1968, p. 141, no. 357; Schaendlinger 1973, p. 107; Sultan 1977, -.

024. $\quad 3.453 \mathrm{~g} ; 22.7 \mathrm{~mm}$.

BoHeMia (?), 2012: unpublished

Murad IV (AH 1032-1049/ 1623-1640 CE), AV sultani, mint: Misr, year unclear [AH 1032/ $1623 \mathrm{CE}$ - private collection built for generations, find possibly.

Obv.: in plain and pearl circles, five lines of Arabic inscriptions - sulțān murād bin | ahmad khān 'azza | nașruhu duriba fi | mișr sana | [982] (Sultan Murad, son | of Selim Khan, may [Allah] guarantee | his victory, struck in | Egypt the year of | [AH 982]), ornaments in the field, slightly ex-centric

Rev.: in plain and pearl circles, four lines of Arabic inscriptions - sulțān al-barrayn | wa chāqān al-bahrayn | al-sultān bin | al-sulțān (sultan of two continents - Europe and Asia Minor | lord of two seas - Aegean Sea and Black Sea | sultan, son | of sultan), ornaments in the field, slightly ex-centric

Lit.: Album 2011, p. 145, no. 1369; Artuk and Artuk 1974, p. 581, no. 1689; Damali 2012, p. 1659, no. 17-MSA1b; Ghalib 1890, pp. 195-196, nos. 506-507; Lane-Poole 1883, p. 124, nos. 336-338; Mitchiner 1977, p. 207, no. 1271; Østrup 1938, p. 297, no. 2564; Pere 1968, p. 158, no. 412; Schaendlinger 1973, p. 110; Sultan 1977, p. 183 , no. 1690 .

025. Metrological data are not known.

South Moravian Region, March 8, 2006: unpublished

Mahmud II (AH 1223-1255/ 1808-1839 CE), AV 1/2 rumi altin, mint: Qustantiniya, AH 1223/ yr. 11 (= AH 1233/ 1818 CE) - single find.

Obv.: in a wreath - sultan's name in the form of tughrä, flower right.

Rev.: in a wreath, four lines of Arabic inscriptions - 11 | duriba fi | qustantīinìya | 1223 (11 | struck in | Qustantiniya | AH 1223).

Lit.: Cuhaj 2009a, 1191 no. 612.

Lovecpokladu.cz, no. 3919 (available at: https://www.lovecpokladu.cz/artefakty/nalez/mince-28639/, 2006).

026. Metrological data are not known, perforation, pendant, chain. 


\section{SILVER COINS}

South Moravian Region, August 27, 2017: unpublished

Murad I (AH 761-791/ 1360-1389 CE), AR akçe, no mint, no date - single find.

Obv.: in plain and pearl circles, two lines of Arabic inscriptions - murād bin $\mid \bar{u} r k h \bar{a} n$ (Murad son | of Urkhan), ornaments above and below, ex-centrically struck.

Rev.: in plain and pearl circles, two lines of Arabic inscriptions divided by three horizontal lines - khullida | mulkahu (may [Allah] perpetuate | his kingdom), ex-centrically struck.

Lit.: Album 2011, p. 141, no. 1289; Artuk and Artuk 1974, -; Damali 2010/1, p. 143, no. 3-G3b, Ghalib 1890, 12, no. 9; Lane-Poole 1883, p. 44, no. 85; Mitchiner 1

977, p. 205, no. 1238; Østrup 1938, p. 288, no. 2482; Pere 1968, p. 51, no. 8; Schaendlinger 1973, p. 87; Srećković 1999, pp. 33-36, nos. 7-26; Sultan 1977, p. 14, nos. 10-16.

Lovecpokladu.cz, no. 5890 (available at: https://www.lovecpokladu.cz/artefakty/nalez/snad-mince-148352/, 2017).

027. $0.7 \mathrm{~g} ; 13 \mathrm{~mm}$.

IvaNČICE (Brno-venkov distr.), 2010: Novák 2011

Murad II (AH 824-848, 849-855 / 1421-1444, 1445-1451 CE), AR akçe, mint: Edirne, AH 825/ 1422 CE - group find of three Ottoman coins.

Obv.: in plain and pearl circles, an Arabic inscription in the form of tughrā-murād bin muhammad 825 (Murad son of Mehmed AH 825), ex-centrically struck.

Rev.: in plain and pearl circles, two lines of Arabic inscriptions divided by three horizontal lines - khullida mulkahu | duriba adarna (may [Allah] perpetuate his kingdom | struck Edirne), ex-centrically struck.

Lit.: Album 2011, p. 142, no. 1302.2; Artuk and Artuk 1974, p. 467, no. 1413; Damali 2010/1, p. 248, no. 6-EDG1-825; Ghalib 1890, pp. 32-33, nos. 45-46; Lane-Poole 1883, -; Mitchiner 1977, -; Østrup 1938, -; Pere 1968, p. 84, no. 53; Schaendlinger 1973, p. 89; Srećković 1999, p. 170, no. 37; Sultan 1977, p. 61, no. 370.

028. $1.000 \mathrm{~g}$; other metrological data are not known.

BĚLÁ POD BEZDĚZEM (Mladá Boleslav distr.), 2015: Novák and Smíšek 2015

Bayezid II (AH 886-918/ 1481-1512 CE), AR akçe, mint: Nowar, year out of flan [AH 886/ 1481 CE] - single find.

Obv.: in plain and pearl circles, four lines of Arabic inscriptions divided by a horizontal line - sulțān | bāyezīd | bin khān | [muhammad] (Sultan/ Bayezid | son of Khan | [Mehmed]).

Rev.: in plain and pearl circles, three lines of Arabic inscriptions divided by a horizontal line - 'azza nașruhu duriba/ nūwār $\mid$ sana ... (may [Allah] guarantee his victory struck | in Nowar the year of ...).

Lit.: Album 2011, p. 142, no. 1312; Artuk and Artuk 1974, p. 492, no. 1484; Ghalib 1890, p. 67, no. 147; LanePoole 1883, p. 64, nos. 151-152; Mitchiner 1977, p. 206, no. 1248; Østrup 1938, -; Pere 1968, p. 100, no. 105; Schaendlinger 1973, p. 94; Srećković 2000, p. 112, nos. 26-30; Sultan 1977, p. 95, nos. 978-986.

029. $0.74 \mathrm{~g} ; 10.1 / 10.3 \mathrm{~mm} ; 5 \mathrm{~h}$, ex-centrically struck, broken.

IvaNČice (Brno-venkov distr.), 2010: Novák 2011

\footnotetext{
Bayezid II (AH 886-918/ 1481-1512 CE), AR akçe, mint: Edirne, AH 886/ 1481 CE group find of three Ottoman coins.

Obv.: in plain and pearl circles, two lines of Arabic inscriptions divided by a horizontal line - sulțān bāyezīd | bin muhammad khān (Sultan Bayezid | son of Mehmed Khan), die larger than flan.

Rev.: in plain and pearl circles, two lines of Arabic inscriptions divided by a horizontal line - 'azza nașruhu duriba | adarna sana 886 (may [Allah] guarantee his victory struck | in Edirne the year of AH 886), excentrically struck.

Lit.: Album 2011, p. 142, no. 1312; Artuk and Artuk 1974, p. 490, no. 1477; Damali 2010/1, p. 324, no. 8-ED-
} 
G1; Ghalib 1890, p. 64, no. 137; Lane-Poole 1883, -; Mitchiner 1977, -; Østrup 1938, p. 295, -; Pere 1968, p. 100, no. 105; Schaendlinger 1973, p. 93; Srećković 2000, p. 108, no. 10; Sultan 1977, p. 94, no. 960.

030 .

$0.714 \mathrm{~g}$; other metrological data are not known.

IvANČICE (Brno-venkov distr.), 2010: Novák 2011

Selim I (AH 918-926/ 1512-1520 CE), AR akçe, mint and date unclear [AH 918/ 1512 CE] - group find of three Ottoman coins.

Obv.: in plain and pearl circles, four lines of Arabic inscriptions divided by a horizontal line in half - sultān | salìm | shāh | bin bāyezìd khān (Sultan | Selim | Shah | son of Bayezid Khan), die larger than flan, not fully struck.

Rev.: in plain and pearl circles, several lines of Arabic inscriptions - 'azza nașruhu... (may [Allah] guarantee his victory ...), ex-centrically and not fully struck.

Lit.: Album 2011, p. 142, no. 1315; Artuk and Artuk 1974, -; Ghalib 1890, -; Lane-Poole 1883, -; Mitchiner 1977, -; Østrup 1938, -; Pere 1968, for the type cf. p. 105, no. 126 (Anqara AH 918); Schaendlinger 1973, -; Srećković 2000; for the type cf. pp. 145-150; Sultan 1977; for the type cf. p. 100, nos. 3-4.

031. $0.641 \mathrm{~g}$; other metrological data are not known.

\section{ČesKÝ Krumlov, 2010: Militký and Novák 2010}

\section{Selim I (AH 918-926/ 1512-1520 CE) AR akçe, mint: Nowár, date worn [AH 918/ 1512} CE] - single find.

Obv.: in plain and pearl circles, four lines of Arabic inscriptions - sulțān $\mid$ salīm $\mid$ shāh | bin bāyezīd khān (Sultan | Selim | Shah | son of Bayezid Khan).

Rev.: in plain and pearl circles, several lines of Arabic inscriptions - 'azza nașruhu duriba | nūwār ... (may [Allah] guarantee his victory struck | Nowar ...).

Lit.: Album 2011, p. 142, no. 1315; Artuk and Artuk 1974, -; Ghalib 1890, p. 75, nos. 176-177; Lane-Poole 1883 , p. 68, nos. 165-167; Mitchiner 1977, -; Østrup 1938, p. 292, no. 2517; Pere 1968, p. 106, no. 142; Schaendlinger 1973, p. 95; Srećković 2000, p. 150, no. 28; Sultan 1977, p. 102, nos. 1051-1054.

032.

$0.659 \mathrm{~g} ; 10.2 / 10 \mathrm{~mm} ; 4.5 \mathrm{~h}$.

Olomouc, 2014: unpublished

A forgery copying the following prototype: Selim I (AH 918-926/ 1512-1520 CE), AR akçe, mint: Qustantiniya, AH 918/ 1512 CE - single find, plated (a contemporary forgery?).

Obv.: in plain and pearl circles, four lines of Arabic inscriptions divided by a horizontal line in half - sultēn salīm | shāh | bin bāyezīd khān (Sultan | Selim | Shah | son of Bayezid Khan), slightly ex-centrically struck. Rev.: in plain and pearl circles, four lines of Arabic inscriptions divided by ornament in half - nașruhu | 'azza duriba | qustantīiniya | sana 918 (his victory | may [Allah] guarantee, struck | Qustantiniya | the year of AH 918), slightly ex-centrically struck.

Lit.: Album 2011, p. 142, no. 1315; Artuk and Artuk 1974, p. 495, no. 1494; Damali 2010/1, p. 390, no. 9-K-G1a; Ghalib 1890, p. 72, no. 164; Lane-Poole 1883, p. 67, nos. 161-162; Mitchiner 1977, p. 206, no. 1250; Østrup 1938, -; Pere 1968, p. 106, no. 136; Schaendlinger 1973, p. 94, Srećković 2000, p. 146, no. 10; Sultan 1977, p. 102, nos. 1035-1036.

033. Metrological data are not known.

Central Bohemia, 2013: unpublished

Suleiman I (AH 926-974/ 1520-1566 CE), AR akçe, mint unclear, AH [9]26/ 1520 CE - single find.

Obv.: in plain and pearl circles, four lines of Arabic inscriptions - sultān $\mid$ shāh $\mid$ suleimān $\mid$... (Sultan $\mid$ Shah | Suleiman | ...), worn. 
Rev.: in plain and pearl circles, six lines of Arabic inscriptions - .. | 'azza/ nașruhu | duriba |...sana | [9]26 (.../may [Allah] guarantee/ his victory | struck | ... the year of | $\mathrm{AH}[9] 26)$, worn.

Lit.: Album 2011, p. 143, no. 1321.1; for the type cf. Pere 1968, p. 114, no. 203.

034. $11 \mathrm{~mm}$; other metrological data are not known, perforation.

MiкuLov (Břeclav distr.), 2014: unpublished

\begin{abstract}
Murad III (AH 982-1003/ 1574-1595 CE), AR akçe, mint and date unclear [AH 982/ $1574 \mathrm{CE}]$ - single find.

Obv.: in plain and pearl circles, three lines of Arabic inscriptions - ... | muräd bin/ salìm khān (... Murad, son | of Selim Khan), worn.

Rev.: in plain and pearl circles, four lines of Arabic inscriptions - 'azza nașruhu $\mid$ duriba $\mid$... (may [Allah] guarantee his victory $\mid$ struck $\mid \ldots$..., worn.

Lit.: Album 2011, p. 144, no. 1336.2; for the type cf. Pere 1968, p. 129, no. 299.
\end{abstract}

035. Metrological data are not known.

South Bohemian Region, December 26, 2016: unpublished

\begin{abstract}
Murad III (AH 982-1003/ 1574-1595 CE), AR akçe, mint: Sidre Qapisi, AH 982/ 1574 CE - single find.

Obv.: in plain and pearl circles, three lines of Arabic inscriptions - ... | murād bin $\mid$ salìm khān (... Murad, son | of Selim Khan), ex-centrically struck.

Rev.: in plain and pearl circles, four lines of Arabic inscriptions - 'azza nașruhu | duriba | sidre qapisī | sana 982 (may [Allah] guarantee his victory | struck | Sidre Qapisi | the year of AH 982), ex-centrically struck. Lit.: Album 2011, p. 144, no. 1336.2; Artuk and Artuk 1974, -; Damali 2011/3, p. 105, no. 12-SD-G3a; Ghalib 1890, p. 136, nos. 351-352; Lane-Poole 1883, p. 91, no. 239; Mitchiner 1977, -; Østrup 1938, -; Pere 1968, p. 129, no. 306; Schaendlinger 1973, p. 102; Srećković 2005, p. 141, nos. 1-5; Sultan 1977, p. 134, nos. 1291-1293.

Lovecpokladu.cz, no. 5532 (available at: https://www.lovecpokladu.cz/artefakty/nalez/mince-127509/, 2016).

036. $10.5 \mathrm{~mm}$, other metrological data are not known.
\end{abstract}

ZNOJMO, 2014: unpublished

Mehmed III (AH 1003-1012/ 1595-1603 CE), AR akçe, mint and date unclear [AH 1003/ $1595 \mathrm{CE}]$ - single find.

Obv.: in plain and pearl circles, three lines of Arabic inscriptions - sulțān $\mid$ muhammad bin murād | khān (Sultan | Mehmed son of Murad | Khan), worn.

Rev.: in a pearl circle - inscriptions totally worn.

Lit.: Album 2011, p. 144, no. 1344.1; for the type cf. Sultan 1977, p. 139, type 1/1.

037.

Metrological data are not known, perforation.

LOUNY-PŘEDMĚSTí (Louny distr.), 2016: Novák 2017

Osman II (AH 1027-1031/ 1618-1622 CE), AR medini, mint out of flan (Misr ?), [AH 1027/ 1618 CE] - single find together with Suleiman I (AH 926-974/ 1520-1566 CE), AV sultani, mint out of flan (fragment), [AH 926/ 1520 CE].

Obv.: [in a pearl circle], three lines of Arabic inscriptions - sulțān | 'uthmān bin | ahmad [khān] (Sultan | Osman son of Ahmed [Khan]).

Rev.: in field, four lines of Arabic inscriptions - 'azza nașruhu | duriba [mișr] | [sana] | [1027] (may [Allah] guarantee his victory | struck [in Egypt] | [the year of] | AH [1027]), central ornament.

Lit.: for the type cf. Pere 1968, p. 153, nos. 402-403 (Misr).

038. $\quad 0.921 \mathrm{~g} ; 13.9 / 14.0 \mathrm{~mm}$; heavily worn. 
BOHEMIA, 2018: unpublished

\begin{abstract}
Ibrahim I (AH 1049-1058/ 1640-1648 CE), AR akçe, mint: Qustantiniya, [AH 1049/ $1640 \mathrm{CE}$ - single find.

Obv.: in plain and pearl circles, three lines of Arabic inscriptions - sulțān | ibrāhīm bin | ahmad khān (Sultan | Ibrahim son | of Ahmed Khan).

Rev.: v ploše čtyřřádkový arabský nápis - 'azza nașruhu | duriba | qusțanținìya | [1049] (may [Allah] guarantee his victory | struck | Qustantiniya | [AH 1049]).

Lit.: Album 2011, p. 145, no. 1381; Artuk - Artuk 1974, p. 585, no. 1696; Damali 2012, p. 1718, no. 18-K-G4; Ghalib 1890, p. 204, nos. 521-522; Lane-Poole 1883, p. 129, nos. 351-353; Mitchiner 1977, -; Østrup 1938, -; Pere 1968, p. 165, no. 440; Schaendlinger 1973, p. 111; Sultan 1977, p. 189, nos. 1764-1766.
\end{abstract}

039. $8 / 9 \mathrm{~mm}$ (based on the photo with scale); other metrological data are not known, perforation.

Central Bohemia, 2013: unpublished

Mehmed IV (AH 1058-1099/ 1648-1687 CE), AR akçe, mint and date unclear [AH 1058/ 1648 CE] - single find.

Obv.: in plain and pearl circles, three lines of Arabic inscriptions - sulțān | muhammad bin | ibrähīm khān (Sultan | Mehmed son | of Ibrahim Khan), ex-centrically struck.

Rev.: in field, three lines of Arabic inscriptions - 'azza nașruhu | ḍriba ... | ... [1058] (may [Allah] guarantee his victory $\mid$ struck ... | .. [AH 1058]), ex-centrically struck.

Lit.: Album 2011, p. 145, no. 1388; for the type cf. Sultan 1977, p. 192, type 1/4.

040. 11/12 mm; other metrological data are not known.

STřítEŽ U JiHLAVy (Jihlava distr.), 2015: unpublished

Mehmed IV (AH 1058-1099/ 1648-1687 CE), AR akçe, mint: Misr, [AH 1058/ 1648 CE] - single find.

Obv.: in a central pearl circle, an Arabic inscription - muhammad (Mehmed), in plain and pearl circles, a circular Arabic inscription - sultān bin ibrāhīm khān (Sultan son of Ibrahim Khan).

Rev.: in field, three lines of Arabic inscriptions divided by a horizontal ornament - khullida mulkahu | duriba mișr | sana [1058] (may [Allah] perpetuate his kingdom | struck Egypt | the year of [AH 1058]).

Lit.: Album 2011, p. 145, no. 1388; for the type cf. Damali 2012, p. 1790, no. 19-MS-G2a.

041. Metrological data are not known, perforation.

South Bohemian Region, August 1, 2018: unpublished

Ahmed III (AH 1115-1143/ 1703-1730 CE), AR 1 para, mint: Islambul, AH 1115/ 1703 CE - single find.

Obv.: in reeded circle, sultan's name in the form of tughrā - khān ahmad bin muhammad al-muzaffar dā'iman (Khan Ahmed son of Mehmed, victorious forever).

Rev.: in reeded circle, three lines of Arabic inscriptions - $f_{\imath} \mid$ islāmbūl $\mid 1115$ waw (in | Islambul | AH 1115 waw letter).

Lit.: Krause and Mishler 1997, p. 1054, no. 141; Pere 1968, p. 194, no. 522.

Lovecpokladu.cz (available at: https://www.lovecpokladu.cz/artefakty/nalez/arabska-mince-176379/, 2018).

042. $0.40 \mathrm{~g} ; 12 \mathrm{~mm}$.

Moravian-Silesian Region, January 1, 2019: unpublished

Ahmed III (AH 1115-1143/ 1703-1730 CE), AR 1 para, mint: Islambul, AH 1115/ 1703

CE - single find.

Obv.: in a reeded circle, sultan's name in the form of tughrā - khān ahmad bin muhammad al-muzaffar dā' iman (Khan Ahmed son of Mehmed, victorious forever). 
Rev.: in a reeded circle, three lines of Arabic inscriptions - $f \hat{\imath} \mid$ islāmbūl $\mid 1115 r \bar{a}^{\prime}$ (in | Islambul | AH 1115 $r a^{\prime}$ letter).

Lit.: Krause and Mishler 1997, p. 1054, no. 141; Pere 1968, p. 194, no. 522.

Lovecpokladu.cz, no. 6069 (available at: https://www.lovecpokladu.cz/artefakty/nalez/jak-na-novy-rok-189961/, 2019).

043. $0.40 \mathrm{~g} ; 12 \mathrm{~mm}$.

NAKLÉŘov (Ústí nad Labem distr.), 2011: Novák 2010

Mustafa III (AH 1171-1187/ 1757-1774 CE), AR 10 para, mint: Islambul, AH 1171/ yr. 82 (= AH 1182/ 1768 CE) - single find, found together with Mahmud II (AH 12231255/ 1808-1839 CE), AR 20 para, mint: Qustantiniya, AH 1223/ yr. 30 (= AH 1252 $=1836 \mathrm{CE}$ ).

Obv.: in plain and pearl circles, sultan's name in the form of tughrā - khān musțafā bin ahmad al-muzaffar dā' iman (Khan Mustafa son of Ahmed, victorious forever), rosette right above.

Rev.: in plain and pearl circles, four lines of Arabic inscriptions - 82 | duriba fi | islāmbül 1171 (82 | struck in | Islambul | AH 1171).

Lit.: Krause and Mishler 1997, p. 1058, no. 305.

044. $3.410 \mathrm{~g} ; 20.5 / 20.4 \mathrm{~mm} ; 0 \mathrm{~h}$, perforation, heavily worn (ideal weight $4.42 \mathrm{~g}$ ).

Central Bohemian Region, August 31, 2018: unpublished

Mustafa III (AH 1171-1187/ 1757-1773 CE), AR 5 para, mint: Islambul, AH 1171/ yr. 84 (= AH 1184/ 1770 CE) - single find.

Obv.: in double plain and pearl circles, sultan's name in the form of tughrā - khān mustafā bin ahmad almuzaffar dā'iman (Khan Mustafa son of Ahmed, victorious forever).

Rev.: in double plain and pearl circles, four lines of Arabic inscriptions - 84 | duriba fì | islāmbūl | 1171 (84 | struck in | Islambul | AH 1171).

Lit.: Krause and Mishler 1997, p. 1058, no. 300.

Lovecpokladu.cz, no. 6027 (available at: https://www.lovecpokladu.cz/artefakty/nalez/4cm-kolo-179300/, 2018).

045. $3.9 \mathrm{~g} ; 16 \mathrm{~mm}$.

South Moravian Region, October 10, 2015: unpublished

Selim III (AH 1203-1222/ 1789-1807 CE), AR 10 para, mint: Islambul, AH 1203/ yr. 5 (= AH 1207/ $1793 \mathrm{CE})$ - single find.

Obv.: in plain and pearl circles, sultan's name in the form of tughrā - khān salìm bin mustafā al-muzaffar dà 'iman (Khan Selim son of Mustafa, victorious forever).

Rev.: in plain and pearl circles, four lines of Arabic inscriptions -5 | duriba fi | islāmbūl | 1203 (5 | struck in | Islambul | AH 1203).

Lit.: Krause and Mishler 1997, p. 1064, no. 492.

Lovecpokladu.cz, no. 4874 (available at: https://www.lovecpokladu.cz/artefakty/nalez/perska-mince-87342/, 2015).

046. Metrological data are not known, traces of pendant.

LySÁ NAD LABEM (Nymburk distr.), 2011: Kubík and Novák 2011

Selim III (AH 1203-1222/ 1789-1807 CE), AR 1 para, mint: Islambul, AH 1203/ yr. 13 (= AH 1215/ $1800 \mathrm{CE})$ - single find.

Obv.: in plain and pearl circles, sultan's name in the form of tughrā - khān salìm bin mustafā al-muzaffar dā'iman (Khan Selim son of Mustafa, victorious forever). 
Rev.: in plain and pearl circles, four lines of Arabic inscriptions - $13 \mid$ duriba fi | islāmbūl | 1203 (13 | struck in | Islambul | AH 1203).

Lit.: Krause and Mishler 1997, p. 1063, no. 486.

047. $\quad 0.390 \mathrm{~g} ; 14.6 / 15 \mathrm{~mm} ; 0 \mathrm{~h}$, perforation, traces of soldering, pendant, heavily worn flan.

\section{MLadÁ BolesLav-Podchlumí, 2012: Harušták and Novák 2013}

Selim III (AH 1203-1222/ 1789-1807 CE), AR 1 para, mint: Misr, AH 1203/ yr. 5 (= AH 1207/ 1793 CE) - hoard of 5 pieces.

Obv.: in plain and pearl circles, sultan's name in the form of tughrā - khān salìm bin musțafā al-muzaffar $d \bar{a}$ 'iman (Khan Selim son of Mustafa, victorious forever).

Rev.: in plain and pearl circles, four lines of Arabic inscriptions - duriba $5|f \hat{\imath}|$ miṣr $\mid 1203$ (struck 5 | in | Misr | 1203).

Lit.: Krause and Mishler 1997, p. 177, no. 134.

048. $\quad 0.189 \mathrm{~g} ; 14.2 / 13.4 \mathrm{~mm} ; 10 \mathrm{~h}$; corrosion, broken and bent flan, severely worn.

049. $0.162 \mathrm{~g} ; 14.8 / 15 \mathrm{~mm} ; 8 \mathrm{~h}$; corrosion, perforation, broken and bent flan, severely worn - enthronization year unclear, different obverse and reverse dies.

050. $\quad 0.255 \mathrm{~g} ; 14.5 / 14.7 \mathrm{~mm} ; 6 \mathrm{~h}$; corrosion, broken and bent flan, severely worn - enthronization year unclear, different obverse and reverse dies.

051. $\quad 0.075 \mathrm{~g} ; 12.2 / 13.4 \mathrm{~mm} ; 11 \mathrm{~h}$; corrosion, broken and bent flan, severely worn - legends (except for mint) worn.

052. $0.051 \mathrm{~g} ; 11 / 13 \mathrm{~mm}$; ? h; heavily corroded, bent, legends worn.

Central Bohemia, May 21, 2017: unpublished

Mahmud II (AH 1223-1255/ 1808-1839 CE), AR 6-piaster, mint: Qustantiniya, AH 1223/ yr. 30 (= AH 1252/ 1837 CE) - single find.

Obv.: in a wreath with pearl and plain circles and four flowers, sultan's name in the form of tughrā - khān mahmūd bin 'abd al-hamìd al-muzaffar dā'iman (Khan Mahmud son of Abdulhamid, victorious forever), right in Arabic 'adli (the Just).

Rev.: in a wreath with pearl and plain circles and four flowers, four lines of Arabic inscriptions - 30 | duriba fi $\mid$ qustanținìya | 1223 (30 | struck in | Qustantiniya | AH 1223).

Lit.: Cuhaj 2009a, p. 1190 no. 603.

Lovecpokladu.cz (available at: https://www.lovecpokladu.cz/artefakty/nalez/mince-124091/0/, 2017).

053. $10.8 \mathrm{~g} ; 37 \mathrm{~mm}$, multiple perforation, bent flan.

Pardubice Region, September 16, 2015: unpublished

Mahmud II (AH 1223-1255/ 1808-1839 CE), AR 5-piaster, mint: Qustantiniya, AH 1223/ yr. 26 (= AH 1248/ 1833 CE) - single find.

Obv.: in a wreath and between two branches, sultan's name in the form of tughrā - khān mahmūid bin 'abd al-hamìd al-muzaffar dā'iman (Khan Mahmud son of Abdulhamid, victorious forever), right in Arabic 'adli (the Just).

Rev.: in a wreath and between two branches, four lines of Arabic inscriptions - 26 | duriba fi | qustantīiniya | 1223 (26 | struck in | Qustantiniya | AH 1223).

Lit.: Cuhaj 2009a, p. 1190 no. 599.

Lovecpokladu.cz, no. 5001 (available at: https://www.lovecpokladu.cz/artefakty/nalez/prosim-o-pomoc-surcenim-101588/, 2015).

054. $14 \mathrm{~g} ; 39 \mathrm{~mm}$, corrosion, bent and broken flan. 
KaRlovy VARY Region, January 8, 2013: unpublished

\begin{abstract}
Mahmud II (AH 1223-1255/ 1808-1839 CE), AR 1 1/2-piaster, mint: Qustantiniya, AH 1223/ yr. 26 (= AH 1248/ 1833 CE) - single find.

Obv.: in a wreath with pearl and plain circles and four flowers, sultan's name in the form of tughrā - khān mahmūid bin 'abd al-hamìd al-muzaffar dà' iman (Khan Mahmud son of Abdulhamid, victorious forever), right in Arabic 'adli (the Just).

Rev.: in a wreath with pearl and plain circles and four flowers, four lines of Arabic inscriptions - 26 | duriba fì | qusțantiniñya | 1223 (26 | struck in | Qustantiniya | AH 1223).

Lit.: Cuhaj 2009a, p. 1190 no. 601.

Lovecpokladu.cz, no. 9648 (available at: https://www.lovecpokladu.cz/artefakty/nalez/urceni-plisku-9648/, 2013).

055. Metrological data are not known, perforation, traces of pendant.
\end{abstract}

Central Bohemia, November 19, 2016: unpublished

Mahmud II (AH 1223-1255/ 1808-1839), AR 1 1/2-piaster, mint: Qustantiniya, AH 1223/ yr. 28 (= AH 1250/ 1835 CE) - single find.

Obv.: in a wreath with pearl and plain circles and four flowers, sultan's name in the form of tughrā - khān mahmī bin 'abd al-hamīd al-muzaffar dā'iman (Khan Mahmud son of Abdulhamid, victorious forever), right in Arabic 'adli (the Just).

Rev.: in a wreath with pearl and plain circles and four flowers, four lines of Arabic inscriptions $-28 \mid$ duriba fi $\mid$ qustantịiniya | 1223 (28 | struck in | Qustantiniya | AH 1223).

Lit.: Cuhaj 2009a, p. 1190 no. 601.

Lovecpokladu.cz (available at: https://www.lovecpokladu.cz/artefakty/nalez/mince-124091/0/, 2016).

056. Metrological data are not known, perforation.

Ústí NAD LABEM Region, February 26, 2014 - unpublished

Mahmud II (AH 1223-1255/ 1808-1839 CE), AR 1 1/2-piaster, mint: Qustantiniya, AH 1223/ yr. 29 (= AH 1251/ 1836 CE) - single find.

Obv.: in a wreath with pearl and plain circles and four flowers, sultan's name in the form of tughrā - khān mahmūd bin 'abd al-hamìd al-muzaffar dā'iman (Khan Mahmud son of Abdulhamid, victorious forever), right in Arabic 'adli (the Just).

Rev.: in a wreath with pearl and plain circles and four flowers, four lines of Arabic inscriptions - 29 | duriba fi $\mid$ qustantininya | 1223 (29 | struck in | Qustantiniya | AH 1223).

Lit.: Cuhaj 2009a, 1190 no. 601.

Lovecpokladu.cz, no. 3623 (available at: https://www.lovecpokladu.cz/artefakty/nalez/nezname-ag-prosimo-urceni-dekuji-36270/, 2014).

057. $25 \mathrm{~mm}$, other metrological data are not known, perforation, traces of pendant, bent flan.

Moravian-Silesian Region, June 4, 2014: unpublished

\footnotetext{
Mahmud II (AH 1223-1255/ 1808-1839 CE), AR 1 piaster, mint: Qustantiniya, AH 1223/ yr. 22 (= AH 1244/ 1829 CE) - single find.

Obv.: in a wreath and between two branches, sultan's name in the form of tughrā - khān mahmiùd bin 'abd al-hamìd al-muzaffar dā'iman (Khan Mahmud son of Abdulhamid, victorious forever), right in Arabic 'adlī (the Just).

Rev.: in a wreath and between two branches, four lines of Arabic inscriptions - $22 \mid$ duriba fi $\mid$ qustantịiniya | 1223 (22 | struck in | Qustantiniya | AH 1223).

Lit.: Cuhaj 2009a, p. 1189 no. 589.

Lovecpokladu.cz (available at: https://www.lovecpokladu.cz/artefakty/nalez/tak-po-delsi-dobe-mince-kterouneznam-44053/, 2014).
}

058. $23 \mathrm{~mm}$, other metrological data are not known, corrosion. 
NAKLÉŘov (Ústí nad Labem distr.), 2011: Novák 2010

Mahmud II (AH 1223-1255/ 1808-1839 CE), AR 20 para, mint: Qustantiniya, AH 1223/ yr. 30 (= AH 1252/ 1836 CE) - single find together with Mustafa III (AH 1171-1187/ 1757-1774 CE), AR 10 para, mint: Islambul, AH 1171/ yr. 82 (= AH 1182/ 1768 CE).

Obv.: in a wreath and between two branches, sultan's name in the form of tughrā - khān mahmüd bin 'abd al-hamìd al-muzaffar dā'iman (Khan Mahmud son of Abdulhamid, victorious forever), right in Arabic 'adli (the Just).

Rev.: in a wreath and between two branches, four lines of Arabic inscriptions - $30 \mid$ duriba fi $\mid$ qustantininiya | 1223 (30 | struck in | Qustantiniya | 1223).

Lit.: Cuhaj 2009a, p. 1190, no. 596.

059. $1.422 \mathrm{~g} ; 24.2 / 24 \mathrm{~mm} ; 11 \mathrm{~h}$, heavily worn, traces of corrosion.

Mikulov (Břeclav distr.), 2013: unpublished

Abdulmejid I (AH 1255-1277/ 1839-1861 CE), BI 20 para, mint: Qustantiniya, AH 1255/ yr. 1 (= AH 1255/ 1839 CE) - single find.

Obv.: in a wreath, sultan's name in the form of tughrā - khān 'abd al-majìd bin mahmūed al-muzaffar dā'iman (Khan Abdulmejid son of Mahmud, victorious forever), branch right.

Rev.: in a wreath, four lines of Arabic inscriptions - 1 | duriba fi | qustantininiya | 1255 (1 | struck in | Qustantiniya | AH 1255).

Lit.: Cuhaj 2009a, p. 1192 no. 653.

060. $1.043 \mathrm{~g} ; 20 / 20 \mathrm{~mm} ; 1 \mathrm{~h}$, heavily worn.

South Moravian Region, January 7, 2013: unpublished

Same - single find together with Abdulmejid I (AH 1255-1277/ 1839-1861 CE), BI 20 para, mint: Qustantiniya, AH 1255/ yr. 2 (= AH 1256/ 1840 CE).

Lovecpokladu.cz (available at: https://www.lovecpokladu.cz/artefakty/nalez/mince-9586/, 2013).

061. Metrological data are not known.

South Moravian Region, May 23, 2013: unpublished

Same - single find.

Lovecpokladu.cz (available at: https://www.lovecpokladu.cz/artefakty/nalez/neznama-18005/, 2013).

062. $18 \mathrm{~mm}$, other metrological data are not known.

Central Bohemian Region, October 20, 2013 - unpublished

Same - single find.

Lovecpokladu.cz (available at: https://www.lovecpokladu.cz/artefakty/nalez/neznama-mince-26525/, 2013).

063. $1.30 \mathrm{~g} ; 20.5 \mathrm{~mm}$.

South Moravian Region, January, 2013 - unpublished

Abdulmejid I (AH 1255-1277/ 1839-1861 CE), BI 20 para, mint: Qustantiniya, AH 1255/ yr. 2 (= AH 1256/ 1840 CE) - single find together with Abdulmejid I (AH 1255-1277/ 1839-1861 CE), BI 20 para, mint: Qustantiniya, AH 1255/ yr. 1 (= AH 1255/ 1839 CE).

Obv.: in a wreath, sultan's name in the form of tughrā - khān 'abd al-majìd bin mahmūd al-muzaffar dā' iman (Khan Abdulmejid son of Mahmud, victorious forever), branch right. 
Rev.: in wreath, four lines of Arabic inscriptions - 2 | duriba fi | qustanțīnīya | 1255 (2 | struck in | Qustantiniya | AH 1255).

Lit.: Cuhaj 2009a, p. 1192 no. 653.

Lovecpokladu.cz (available at: https://www.lovecpokladu.cz/artefakty/nalez/mince-9586/, 2013).

064. Metrological data are not known.

MoRAVSKÁ Třebová, 2018: unpublished

Same - single find.

065. $1.25 \mathrm{~g} ; 20.1 / 19.9 \mathrm{~mm} ; 5 \mathrm{~h}$, heavily worn.

Olomouc Region, October 20, 2012: unpublished

Abdulaziz (AH 1277-1293/ 1861-1876 CE), AR 5-piaster, mint: Qustantiniya, AH 1277/ yr. X (= ?) - single find.

Obv.: in arches with stars, sultan's name in the form of tughrā - khān 'abd al-'azīz bin mahmūid al-muzaffar dā' iman (Khan Abdulaziz son of Mahmud, victorious forever), below - two lines of Arabic inscriptions - X | sana $(\mathrm{X} \mid$ the year of).

Rev.: in arches with stars, four lines of Arabic inscriptions - 'azza nașruhu | ḍuriba fi | qustanținīya $\mid 1277$ (may [Allah] guarantee his victory | struck in | Qustantiniya | AH 1277).

Lit.: Cuhaj 2009a, p. 1196 no. 691.

Lovecpokladu.cz, no. 3581 (available at: https://www.lovecpokladu.cz/artefakty/nalez/turecka-mince-7812/, 2012).

066. $3.0 \mathrm{~g} ; 22 \mathrm{~mm}$, modified for button.

PlzeŇ Region, September 9, 2016: unpublished

\begin{abstract}
Abdulaziz (AH 1277-1293/ 1861-1876 CE), AR 5-piaster, mint: Qustantiniya, AH 1277/ yr. 10 (= AH 1286/ 1870 CE) - single find.

Obv.: in arches with stars, sultan's name in the form of tughrā - khān 'abd al-'azīz bin mahmūd al-muzaffar dā'iman (Khan Abdulaziz son of Mahmud, victorious forever), below - two lines of Arabic inscriptions - 10 | sana (10 | the year of).

Rev.: in arches with stars, four lines of Arabic inscriptions - 'azza nașruhu | duriba fì | qusțanținìya 1277 (may [Allah] guarantee his victory | struck in | Qustantiniya | AH 1277).

Lit.: Cuhaj 2009a, p. 1196 no. 691.

Lovecpokladu.cz (available at: https://www.lovecpokladu.cz/artefakty/nalez/arabska-mince-117665/, 2016).

067. $6.0 \mathrm{~g} ; 24 \mathrm{~mm}$, pendant.
\end{abstract}

ÚJEZDEC (Svitavy distr.), 2012: Hrubeš and Novák 2011

Murad V (AH 1293/ 1876 CE), AR 1 piaster, mint: Qustantiniya, AH 1293/ yr. 1 (= AH 1293/ 1876 CE) - single find together with dispersed Austrian coins (Maria Theresa 1740-1780: AE kreuzer 1765, Franz Joseph I 1848-1916: AE kreuzer 1859, AE 2 heller 1904, AE heller 1897, AE heller with unspecified date and AE fillér with unclear date), plus two unspecified and heavily corroded Czechoslovak coins, struck sometime between 1945 and 1953 .

Obv.: in a circle of twelve five-pointed stars, sultan 's name in the form of tughrā - khān murād bin 'abd al-majīd almuzaffar dā'iman (Khan Murad son of Abdulmejid, victorious forever), below - in Arabic sana 1 (the year of 1). Rev.: in a circle of twelve five-pointed stars, four lines of Arabic inscriptions - 'azza nașruhu | duriba fi | qustanținìya | 1293 (may [Allah] guarantee his victory | struck in | Qustantiniya | AH 1293).

Lit.: Cuhaj 2009a, p. 1196, no. 710.

068. $1.055 \mathrm{~g} ; 14.8 / 14.7 \mathrm{~mm} ; 0 \mathrm{~h}$; trace of a cut on obverse, bent in half. 
Abdulhamid II (AH 1293-1327/ 1876-1909 CE), AR 2-piaster, mint: Qustantiniya, AH 1293/ yr. 23 (= AH 1315/ 1898 CE) - single find.

Obv.: in a reeded border and circle of twelve five-pointed stars, sultan's name in the form of tughrā khān 'abd al-hamìd bin 'abd al-majìd al-muzaffar dā'iman (Khan Abdulhamid son of Abdulmejid, victorious forever), below - two lines of Arabic inscriptions - 23 | sana (23 | the year of), right in Arabic - ghāzi (the Warrior).

Rev.: in a reeded border and circle of twelve five-pointed stars, four lines of Arabic inscriptions - 'azza nașruhu | duriba fi | qusțanținīya | 1293 (may [Allah] guarantee his victory | struck in | Qustantiniya | AH 1293). Lit.: Cuhaj 2009a, p. 1197 no. 736.

Lovecpokladu.cz (available at: https://www.lovecpokladu.cz/artefakty/nalez/mince-148363/, 2017);

Lovecpokladu.cz, no. 5854 (available at: https://www.lovecpokladu.cz/artefakty/nalez/mince-148364/, 2017).

069. $2.4 \mathrm{~g} ; 18 \mathrm{~mm}$, modified for button.

Central Bohemian Region, April 12, 2018: unpublished

\begin{abstract}
Abdulhamid II (AH 1293-1327/ 1876-1909 CE), AR 2-piaster, mint: Qustantiniya, AH 1293/ yr. 26 (= AH 1318/ 1901 CE) - single find.

Obv.: in a reeded border and circle of twelve five-pointed stars, sultan's name in the form of tughrā khān 'abd al-hamìd bin 'abd al-majìd al-muzaffar dā'iman (Khan Abdulhamid son of Abdulmejid, victorious forever), below - two lines of Arabic inscriptions - 26 | sana (26 | the year of), right in Arabic - ghāzi (the Warrior).

Rev.: in a reeded border and circle of twelve five-pointed stars, four lines of Arabic inscriptions - 'azza nașruhu | duriba fì | qustantīiniya | 1293 (may [Allah] guarantee his victory | struck in | Qustantiniya | AH 1293). Lit.: Cuhaj 2009a, p. 1197 no. 736.

Lovecpokladu.cz (available at: https://www.lovecpokladu.cz/artefakty/nalez/mince-168974/, 2018).
\end{abstract}

070. $2.0 \mathrm{~g} ; 18 \mathrm{~mm}$, bowl-like shape of flan.

Central Bohemia, August 21, 2017: unpublished

\begin{abstract}
Abdulhamid II (AH 1293-1327/ 1876-1909 CE), AR 1 piaster, mint: Qustantiniya, AH 1293/ yr. 9 (= AH 1301/ 1884 CE) - single find.
\end{abstract}

Obv.: in a reeded border and circle of twelve five-pointed stars, sultan's name in the form of tughrā - khān 'abd al-hamìd bin 'abd al-majìd al-muzaffar dā' iman (Khan Abdulhamid son of Abdulmejid, victorious forever), below - two lines of Arabic inscriptions - $9 \mid$ sana (9 | the year of), right in Arabic - ghāzi (the Warrior).

Rev.: in a reeded border and circle of twelve five-pointed stars, four lines of Arabic inscriptions - 'azza nașruhu | duriba fi | qusțantininya | 1293 (may [Allah] guarantee his victory | struck in | Qustantiniya | AH 1293).

Lit.: Cuhaj 2009a, p. 1197 no. 735.

Lovecpokladu.cz (available at: https://www.lovecpokladu.cz/artefakty/nalez/osmansky-prcek-147681/, 2017).

071. Metrological data are not known, perforation.

South Bohemian Region, November 20, 2017: unpublished

\begin{abstract}
Abdulhamid II (AH 1293-1327/ 1876-1909 CE), AR 1 piaster, mint: Qustantiniya, AH 1293/ yr. 16 (= AH 1308/ 1891 CE) - single find.

Obv.: in a reeded border and circle of twelve five-pointed stars, sultan's name in the form of tughrā - khān 'abd al-hamīd bin 'abd al-majìd al-muzaffar dā' iman (Khan Abdulhamid son of Abdulmejid, victorious forever), below - two lines of Arabic inscriptions - 16 | sana (16 | the year of), right in Arabic - ghāzi (the Warrior).

Rev.: in a reeded border and circle of twelve five-pointed stars, four lines of Arabic inscriptions - 'azza nașruhu | duriba fì | qustanținìya | 1293 (may [Allah] guarantee his victory | struck in | Qustantiniya | AH 1293). Lit.: Cuhaj 2009a, p. 1197 no. 735.

Lovecpokladu.cz (available at: https://www.lovecpokladu.cz/artefakty/nalez/ag-neco-d-156281/, 2017).
\end{abstract}

072. Metrological data are not known, modified for button. 


\begin{abstract}
Abdulhamid II (AH 1293-1327/ 1876-1909 CE), AR 1 piaster, mint: Qustantiniya, AH 1293/ yr. 23 (= AH 1315/ 1898 CE) - single find.

Obv.: in a reeded border and circle of twelve five-pointed stars, sultan's name in the form of tughrā - khān 'abd al-hamìd bin 'abd al-majìd al-muzaffar dā' iman (Khan Abdulhamid son of Abdulmejid, victorious forever), below - two lines of Arabic inscriptions - $23 \mid$ sana (23 | the year of), right in Arabic - ghāzi (the Warrior).

Rev.: in a reeded border and circle of twelve five-pointed stars, four lines of Arabic inscriptions - 'azza nassruhu | duriba fi | qusțantînīya | 1293 (may [Allah] guarantee his victory | struck in | Qustantiniya | AH 1293). Lit.: Cuhaj 2009a, 1197 no. 735.

Lovecpokladu.cz (available at: https://www.lovecpokladu.cz/artefakty/nalez/poradte-co-je-to-mince-arabacdekuju-179638/, 2018).
\end{abstract}

073. $15 \mathrm{~mm}$, other metrological data are not known, modified for button.

BoHEMIA, November 17, 2014: unpublished

\begin{abstract}
Abdulhamid II (AH 1293-1327/ 1876-1909 CE), AR 1 piaster, mint: Qustantiniya, AH 1293/ yr. 25 (= AH 1317/ 1900 CE) - single find.

Obv.: in a reeded border and circle of twelve five-pointed stars, sultan's name in the form of tughrā - khān 'abd al-hamìd bin 'abd al-majìd al-muzaffar dā' 'iman (Khan Abdulhamid son of Abdulmejid, victorious forever), below - two lines of Arabic inscriptions - $25 \mid$ sana (25 | the year of), right in Arabic - ghäzi (the Warrior).

Rev.: in a reeded border and circle of twelve five-pointed stars, four lines of Arabic inscriptions - 'azza nassruhu | duriba fì | qustanținìya | 1293 (may [Allah] guarantee his victory | struck in | Qustantiniya | AH 1293). Lit.: Cuhaj 2009a, p. 1197 no. 735.

Lovecpokladu.cz, no. 4208 (available at: https://www.lovecpokladu.cz/artefakty/nalez/mince-58218/, 2014).

074. $14 \mathrm{~mm}$, other metrological data are not known.
\end{abstract}

\title{
COPPER COINS
}

LOUČKA (Vsetín distr.), reported 2014: unpublished

Mehmed I Çelebi (AH 806-816/ 1403-1413 CE), AE manghir, mint: Brusa, no date admixture of a hoard of ancient coins (ancient coins, terminus post quem the $6^{\text {th }}$ century $\mathrm{AD}$ - a French $\mathrm{AE}$ coin of the $16^{\text {th }} / 17^{\text {th }}$ century also registered - the hoard remained unpublished.

Obv.: in plain and pearl circles, sultan's name in the form of tughrā -muhammad bin sultān bāyezīd (Mehmed son of Sultan Bayezid).

Rev.: in plain and pearl circles, two lines of Arabic inscriptions divided by a horizontal line - khullida mulkahu | duriba brusa (may [Allah] perpetuate his kingdom | struck in Brusa).

Lit.: Kabaklarli 1998, pp. 93-94, nos. 06-13.

075. $\quad 0.917 \mathrm{~g} ; 15.6 / 14.1 \mathrm{~mm} ; 6 \mathrm{~h}$; irregular flan, legends partly off.

JAROMĚ̌̌, 2014: Novák 2015

Mehmed IV (AH 1058-1099/ 1648-1687 CE), AE manghir, mint: Tarabulus Gharb, date out of the preserved legend (1668-1679 CE by type) - group find of three coins (two of them Chinese).

Obv.: in plain and pearl circles, three lines of Arabic inscriptions - sulțān | muhammad khān | [bin] ibrāhīm (Sultan | Mehmed | [son] of Ibrahim Khan)

Rev.: in plain and pearl circles, five lines of Arabic inscriptions - duriba $\mid$ fi țarābulus $\mid$ gharb $\mid$ sana $\mid$... (struck | in Tarabulus | Gharb | the year of | ...). 
Lit.: Kabaklarli 1998, pp. 478-480, nos. 19-Trbg-01-13.

076. $\quad 3.027 \mathrm{~g} ; 17.5 / 13.8 \mathrm{~mm} ; 8 \mathrm{~h}$; irregular flan, legends partly off.

TřEBíč, 2011: unpublished

\section{A forgery copying the following prototype: Suleiman II (AH 1099-1102/ 1687-1691} CE), AE manghir, mint: Qustantiniya, AH 1099/ 1687 CE - single find, settlement of the $8^{\text {th }}-9^{\text {th }}$ centuries in west Moravia, very likely a contemporary forgery.

Obv.: in a reeded circle, sultan's name in the form of tughrā.

Rev.: in a reeded circle, four lines of Arabic inscriptions - .. | duriba fi | qustanținiña | 1099 (... struck in | Qustantiniya | AH 1099), retrograde name of mint.

Lit.: Kabaklarli 1998, for the type cf. p. 491, nos. 09-12 (contemporary forgeries).

077. Metrological data are not known (19 mm based on the photo with scale), debased metal, heavily worn.

NÁchod Region, 2014: unpublished

A forgery copying the following prototype: Suleiman II (AH 1099-1102/ 1687-1691 CE), AE piaster (sic!), mint: Qustantiniya, AH 1099/ 1687 CE - group find of individual pieces, a copper coin copying a heavy silver coin, debased retrograde calligraphy - most likely a contemporary forgery (European?).

Obv.: in plain and pearl circles, five lines of Arabic inscriptions - sulțān suleimān | bin ibrāhīm | dāma mulkahu duriba fì | qustanținīya | 1099 (Sultan Suleiman | son of Ibrahim | may [Allah] perpetuate his kingdom struck in | Qustantiniya | AH 1099).

Rev.: in plain and pearl circles, four lines of Arabic retrograde inscriptions - sulțān al-barrayn | wa khāqān al-bahrayn | al-sulțān bin | al-sulțān (sultan of two continents - Europe and Asia Minor | lord of two seas Aegean Sea and Black Sea | sultan, son | of sultan).

Lit.: Pere 1968, for the type cf. p. 176, no. 468.

078. Metrological data are not known (40 $\mathrm{mm}$ based on the photo with scale), debased metal.

South Moravian Region, April 28, 2013: unpublished

Suleiman II (AH 1099-1102/ 1687-1691 CE), AE manghir, mint: Qustantiniya, [AH 1099/ 1687 CE] - single find.

Obv.: in reeded and plain circles, sultan's name in the form of tughrā centrally, ornaments in the field.

Rev.: in reeded and plain circles, three lines of Arabic inscriptions - duriba fi | qusțanținìya | [1099] (struck in | Qustantiniya | [AH 1099]), ornaments in the field.

Lit.: Kabaklarli 1998, pp. 490-491, nos. 01-08; Pere 1968, p. 177, no. 471.

Lovecpokladu.cz (available at: https://www.lovecpokladu.cz/artefakty/nalez/prosim-o-urceni-16632/, 2013).

079. Metrological data are not known, heavily worn.

MĚLNíK, February 2, 2015: unpublished

Suleiman II (AH 1099-1102/ 1687-1691 CE), AE manghir, mint: [Qustantiniya], [AH 1099/ 1687 CE] - single find.

Obv.: sultan's name in the form of tughrā centrally.

Rev.: three lines of Arabic inscriptions in the field, - duriba fi | [qustantīinìya | 1099] (struck in | [Qustantiniya ( AH 1099]).

Lit.: Kabaklarli 1998, pp. 490-491, nos. 01-08; Pere 1968: p. 177, no. 471.

Lovecpokladu.cz (available at: https://www.lovecpokladu.cz/artefakty/nalez/mangir-sulejman-ii-odlabe-65315/, 2015).

080. Metrological data are not known, heavily worn. 
South Moravian Region, January 25, 2016: unpublished

Same - single find.

Lovecpokladu.cz, no. 3701 (available at: https://www.lovecpokladu.cz/artefakty/nalez/mince-97218/, 2016).

081. $20 \mathrm{~mm}$; other metrological data are not known, ex-centrically struck.

Bohemia (?), April 4, 2016: unpublished

Same - single find.

Lovecpokladu.cz (available at: https://www.lovecpokladu.cz/artefakty/nalez/je-to-mince-114633/, 2016).

082. $17 \mathrm{~mm}$; other metrological data are not known, traces of pendant.

Moravian-Silesian Region, October 14, 2016: unpublished

Same - single find.

Lovecpokladu.cz (available at: https://www.lovecpokladu.cz/artefakty/nalez/mince-120765/, 2016).

083. Metrological data are not known.

South Bohemian Region, August 15, 2017: unpublished

Same - single find.

Lovecpokladu.cz (available at: https://www.lovecpokladu.cz/artefakty/nalez/prosim-o-radu-s-urcenim-147174/, 2017).

084. Metrological data are not known, bent flan.

South Moravian Region, September 30, 2017: unpublished

Same - single find.

Lovecpokladu.cz (available at: https://www.lovecpokladu.cz/artefakty/nalez/suleyman-ii-153154/, 2017).

085. $1.30 \mathrm{~g} ; 19 \mathrm{~mm}$, broken flan (10\%).

\section{South Moravian Region, November 12, 2017: unpublished}

Same - single find.

Lovecpokladu.cz (available at: https://www.lovecpokladu.cz/artefakty/nalez/mince-155596/, 2017).

086. Metrological data are not known.

Central Bohemian Region, March 10, 2018: unpublished

Same - single find.

Lovecpokladu.cz (available at: https://www.lovecpokladu.cz/artefakty/nalez/turek-164945/, 2018).

087. $19 \mathrm{~mm}$, other metrological data are not known, centrally holed, worn.

Central Bohemian Region, June 7, 2018: unpublished

Same - single find.

Lovecpokladu.cz (available at: https://www.lovecpokladu.cz/artefakty/nalez/prosim-o-urceni-172390/, 2018).

088. $20 \mathrm{~mm}$, other metrological data are not known, bent flan, worn. 
BoHEMIA, November 17, 2015: unpublished

Suleiman II (AH 1099-1102/ 1687-1691 CE), AE manghir, mint: Saray, AH 1100/ 1688

CE - single find.

Obv.: totally worn.

Rev.: in plain and pearl circles, three lines of Arabic inscriptions - duriba fí | sarāy | 1100 (struck in | Saray | AH 1100), heavily worn.

Lit.: Kabaklarli 1998, pp. 490-491, nos. 01-08; Pere 1968: p. 177, no. 471.

Lovecpokladu.cz (available at: https://www.lovecpokladu.cz/artefakty/nalez/medena-stara-mince-90738/, 2015).

089. Metrological data are not known.

Central Bohemia, 2014: unpublished

\begin{abstract}
Abdulmejid I (AH 1255-1277/ 1839-1861 CE), AE 20 para, mint: Qustantiniya, AH 1255/ yr. 19 (= AH 1273/ 1857 CE) - single find.
\end{abstract}

Obv.: in a reeded circle, sultan's name in the form of tughrā - khān 'abd al-majīd bin mahmū al-muzaffar $d \bar{a}$ 'iman (Khan Abdulmejid son of Mahmud, victorious forever), below two lines of Arabic inscriptions - 19 | sana (19 | the year of), flower right.

Rev.: in a reeded circle, numeral 20 centrally, a circular Arabic inscription around - duriba fi qusțantīnìya sana 1255 (struck in Qustantiniya the year of AH 1255).

Lit.: Cuhaj 2009a, p. 1193 no. 668.1.

090. Metrological data are not known, modified for button.

Moravia (?), June 26, 2009: unpublished

\begin{abstract}
Abdulmejid I (AH 1255-1277/ 1839-1861 CE), AE 10 para, mint: Qustantiniya, AH 1255/ yr. 20 (= AH 1274/ 1858 CE) - single find.
\end{abstract}

Obv.: in a reeded circle, sultan's name in the form of tughrā - khān 'abd al-majīd bin mahmū al-muzaffar dā'iman (Khan Abdulmejid son of Mahmud, victorious forever), below two lines of Arabic inscriptions - 20/ sana (20/ the year of), flower right.

Rev.: in a reeded circle, numeral 10 centrally, a circular Arabic inscription around - duriba fi qustantīninya sana 1255 (struck in Qustantiniya the year of AH 1255).

Lit.: Cuhaj 2009a, p. 1193 no. 667.3.

Lovecpokladu.cz, no. 3280 (available at: https://www.lovecpokladu.cz/artefakty/nalez/mince-744-1008/, 2009).

091. Metrological data are not known, perforation.

BOHEMIA, December 27, 2018: unpublished

\begin{abstract}
Abdulaziz (AH 1277-1293/ 1861-1876 CE), AE 40 para, mint: Qustantiniya, AH 1277/ yr. 4 (= AH 1280/ 1864 CE) - single find.

Obv.: in a reeded circle, sultan's name in the form of tughrā - khān 'abd al-'azizz bin mahmūid al-muzaffar dà'iman (Khan Abdulaziz son of Mahmud, victorious forever), below two lines of Arabic inscriptions - 4 । sana (4 | the year of).

Rev.: in a reeded circle, numeral 40 centrally, a circular Arabic inscription around - duriba fi qusțanținìya sana 1277 (struck in Qustantiniya the year of AH 1277).

Lit.: Cuhaj 2009a, p. 1195 no. 702.

Lovecpokladu.cz, no. 6060 (available at: https://www.lovecpokladu.cz/artefakty/nalez/prosim-ourceni-189417/, 2018).
\end{abstract}

092. $36 \mathrm{~mm}$, other metrological data are not known. 

yr. 4 (= AH 1280/ 1864 CE) - single find.

Obv.: in a reeded circle, sultan's name in the form of tughrā - khān 'abd al-'aziz bin mahmūd al-muzaffar dā'iman (Khan Abdulaziz son of Mahmud, victorious forever), below two lines of Arabic inscriptions - 4 । sana (4 | the year of).

Rev.: in a reeded circle, numeral 20 centrally, a circular Arabic inscription around - duriba fi qustantīiniya sana 1277 (struck in Qustantiniya the year of AH 1277).

Lit.: Cuhaj 2009a, p. 1195 no. 701.

Lovecpokladu.cz (available at: https://www.lovecpokladu.cz/artefakty/nalez/nalez-v-lese-20-para-1865-190094/, 2009).

093. $32 \mathrm{~mm}$, other metrological data are not known, scratches.

Karlovy Vary Region, April 28, 2017: unpublished

Same - single find.

Lovecpokladu.cz, no. 5406 (available at: https://www.lovecpokladu.cz/artefakty/nalez/mince-138356/, 2017).

094. $10.65 \mathrm{~g} ; 32 \mathrm{~mm}$, corrosion.

South Bohemian Region, September 19, 2018: unpublished

Abdulaziz (AH 1277-1293/ 1861-1876), AE 10 para, mint: Qustantiniya, AH 1277/ yr. 1 (= AH 1277 = AD 1861) - single find.

Obv.: in a reeded circle, sultan's name in the form of tughrā - khān 'abd al-'aziz bin mahmūd al-muzaffar dé 'iman (Khan Abdulaziz son of Mahmud, victorious forever), centrally two lines of Arabic inscriptions - 1

| sana (1 | the year of), below Turkish inscription in Arabic script - dersaadete mahsus sikke-i nuhasiyedir (this copper coin belongs to the blessed place - Istanbul).

Rev.: in a reeded circle, numeral 10 centrally, a circular Arabic inscription around - duriba fi qustantīinìa sana 1277 (struck in Qustantiniya the year of AH 1277).

Lit.: Cuhaj 2009a, p. 1195 no. 686.

Lovecpokladu.cz (available at: https://www.lovecpokladu.cz/artefakty/nalez/prosim-o-urceni-mincearabska-181275/, 2018).

095. $5.0 \mathrm{~g} ; 27 \mathrm{~mm}$, corrosion.

Vysočina Region, March 18, 2012: unpublished

Abdulaziz (AH 1277-1293/ 1861-1876 CE), AE 10 para, mint: Qustantiniya, AH 1277/ yr. 4 (= AH 1280/ 1864 CE) - single find.

Obv.: in a reeded circle, sultan's name in the form of tughrā - khān 'abd al-'aziz bin mahmūid al-muzaffar dā'iman (Khan Abdulaziz son of Mahmud, victorious forever), below two lines of Arabic inscriptions - 4 । sana $(4 \mid$ the year of).

Rev.: in a reeded circle, numeral 10 centrally, a circular Arabic inscription around - duriba fi qusțantīnìya sana 1277 (struck in Qustantiniya the year of AH 1277).

Lit.: Cuhaj 2009a, p. 1195 no. 700.

Lovecpokladu.cz (available at: https://www.lovecpokladu.cz/artefakty/nalez/mince-3936-3805/, 2012).

096. Metrological data are not known, broken flan (some 30\% missing).

\section{Moravian-Silesian Region, March 2, 2013: unpublished}

Same - single find.

Lovecpokladu.cz (available at: https://www.lovecpokladu.cz/artefakty/nalez/kdo-poradi-13252/, 2013).

097. Metrological data are not known, four perforations. 
Olomouc Region, October 14, 2017: unpublished

Same - single find.

Lovecpokladu.cz (available at: https://www.lovecpokladu.cz/artefakty/nalez/medailonek-ci-mince-153949/, 2017).

098. $28 \mathrm{~mm}$, other metrological data are not known, perforation.

BoHEMIA, December 3, 2014: unpublished

Abdulaziz (AH 1277-1293/ 1861-1876 CE), AE 10 para, mint: Misr, AH 1277/ yr. 4 (= AH 1280/ 1864 CE) - single find.

Obv.: in a reeded circle, sultan's name in the form of tughrā - khān 'abd al-'aziz bin mahmūd al-muzaffar dā'iman (Khan Abdulaziz son of Mahmud, victorious forever), below two lines of Arabic inscriptions - 10। $p$ (10 | para).

Rev.: in a reeded circle, four lines of Arabic inscriptions - 4 | duriba fi | mișr | 1277 (4 | struck in | Egypt | AH 1277).

Lit.: Cuhaj 2009a, p. 302 no. 241.

Lovecpokladu.cz, no. 4240 (available at: https://www.lovecpokladu.cz/artefakty/nalez/znamka-59560/, 2014).

099. Metrological data are not known, perforation.

South Moravian Region, January 19, 2013: unpublished

Abdulaziz (AH 1277-1293/ 1861-1876 CE), AE 10 para, mint: Misr, AH 1277/ yr. 5 (= AH 1281/ 1865 CE) - single find.

Obv.: in a reeded circle, sultan's name in the form of tughrā - khān 'abd al-'azīz bin mahmūd al-muzaffar dā' iman (Khan Abdulaziz son of Mahmud, victorious forever), below two lines of Arabic inscriptions - 10। $p$ (10 | para).

Rev.: in a reeded circle, four lines of Arabic inscriptions - 5 | duriba fi | mișr | 1277 (5 | struck in | Egypt | AH 1277).

Lit.: Cuhaj 2009a, p. 302 no. 241.

Lovecpokladu.cz (available at: https://www.lovecpokladu.cz/artefakty/nalez/arabska-mince-10677/, 2013).

100. Metrological data are not known, corrosion.

Central Bohemian Region, June 18, 2017: unpublished

Same - single find.

Lovecpokladu.cz (available at: https://www.lovecpokladu.cz/artefakty/nalez/je-to-mince-142428/, 2017).

101. $30 \mathrm{~mm}$, other metrological data are not known, corrosion.

South Moravian Region, February 23, 2006: unpublished

Abdulaziz (AH 1277-1293/ 1861-1876 CE), AE 10 para, mint: Misr, AH 1277/ yr. 6 (= AH 1282/ 1866 CE) - single find.

Obv.: in a reeded circle, sultan's name in the form of tughrā - khān 'abd al-'aziz bin mahmūd al-muzaffar dā'iman (Khan Abdulaziz son of Mahmud, victorious forever), below two lines of Arabic inscriptions - 10 | $p(10 \mid$ para $)$.

Rev.: in a reeded circle, four lines of Arabic inscriptions - 6 | duriba fi | mișr | 1277 (6 | struck in | Egypt | AH 1277).

Lit.: Cuhaj 2009a, p. 302 no. 241.

Lovecpokladu.cz (available at: https://www.lovecpokladu.cz/artefakty/nalez/mince-27841/, 2006).

102. $30 \mathrm{~mm}$, other metrological data are not known, worn flan. 
KarLovy Vary Region, July 17, 2018: unpublished

Abdulaziz (AH 1277-1293/ 1861-1876 CE), AE 5 para, mint: Qustantiniya, AH 1277/ yr. 4 (= AH 1280/ 1864 CE) - single find.

Obv.: in a reeded circle, sultan's name in the form of tughrā - khān 'abd al-'aziz bin mahmūd al-muzaffar dā'iman (Khan Abdulaziz son of Mahmud, victorious forever), below two lines of Arabic inscriptions - 4 । sana $(4 \mid$ the year of).

Rev.: in a reeded circle, numeral 5 centrally, a circular Arabic inscription around - 'azza nașruhu duriba fi qusțantininya sana 1277 (may [Allah] guarantee his victory, struck in Qustantiniya the year of AH 1277).

Lit.: Cuhaj 2009a, p. 1195 no. 699.

Lovecpokladu.cz, no. 5928 (available at: https://www.lovecpokladu.cz/artefakty/nalez/neznamamince-174872/, 2018).

103. $3.0 \mathrm{~g} ; 22 \mathrm{~mm}$, modified for button.

KARLOVY VARY Region, January 20, 2013: unpublished

\section{Mehmed V (AH 1327-1336/ 1909-1918 CE), AE 20 para, mint: Qustantiniya, AH} 1327/ yr. 3 (= AH 1329/1911 CE) - single find.

Obv.: in a reeded circle, sultan's name in the form of tughrā - khān muhammad bin 'abd al-majìd al-muzaffar dà 'iman (Khan Mehmed son of Abdulmejid, victorious forever), below two lines of Arabic inscriptions $3 \mid$ sana (3 | the year of), right in Arabic reshād (the True Path Follower), a pearl circle, in the margin a wreath and an Arabic inscription divided by stars - hurrīya | musāwāt | 'adāla (freedom | equality | justice).

Rev.: in a reeded circle, two lines of Arabic inscriptions - $20 \mid$ pāra $(20 \mid$ para), a pearl circle below in a wreath in Arabic 1327 (AH 1327), above an Arabic inscription divided by stars - duriba fi | dawla uthmānìya | qustanținìya (struck in | Ottoman state | Qustantiniya).

Lit.: Cuhaj 2009b, p. 2065 no. 761.

Lovecpokladu.cz, no. 3509 (available at: https://www.lovecpokladu.cz/artefakty/nalez/urceni-mince-10737/, 2013).

104. $3.8 \mathrm{~g} ; 21.2 \mathrm{~mm}$.

BOHEMIA, July 27, 2016: unpublished

Same - single find.

Lovecpokladu.cz (available at: https://www.lovecpokladu.cz/artefakty/nalez/para-128681/, 2016).

105. Metrological data are not known.

\section{South Moravian Region, July 27, 2013: unpublished}

Mehmed V (AH 1327-1336/ 1909-1918 CE), AE 20 para, mint: Qustantiniya, AH 1327/ yr. 5 (= AH 1331/ 1913 CE) - single find.

Obv.: in a reeded circle, sultan's name in the form of tughrā - khān muhammad bin 'abd al-majīd al-muzaffar da' 'iman (Khan Mehmed son of Abdulmejid, victorious forever below two lines of Arabic inscriptions 5 | sana (5 | the year of), right in Arabic reshād (the True Path Follower), a pearl circle, in the margin a wreath and an Arabic inscription divided by stars - hurrīya | musāwāt | 'adāla (freedom | equality | justice).

Rev.: in a reeded circle, two lines of Arabic inscriptions - $20 \mid$ pāra $(20 \mid$ para), a pearl circle below in a wreath in Arabic 1327 (AH 1327), above an Arabic inscription divided by stars - duriba fì | dawla uthmānīya | qusțanținìya (struck in | Ottoman state | Qustantiniya).

Lit.: Cuhaj 2009b, p. 2065 no. 761.

Lovecpokladu.cz (available at: https://www.lovecpokladu.cz/artefakty/nalez/20-para-turecko-1909mehmet-v-20976/, 2013).

106. $4.0 \mathrm{~g} ; 21 \mathrm{~mm}$. 
Mehmed V (AH 1327-1336/ 1909-1918 CE), AE 10 para, mint: Qustantiniya, AH 1327/ yr. 2 (= AH 1328/ 1910 CE) - single find.

Obv.: in a reeded circle, sultan's name in the form of tughrā - khān muhammad bin 'abd al-majìd al-muzaffar dā' 'iman (Khan Mehmed son of Abdulmejid, victorious forever), below two lines of Arabic inscriptions - 2 । sana (2 | the year of), right in Arabic reshād (the True Path Follower), a pearl circle, in the margin - a wreath and an Arabic inscription divided by stars - hurrīya | musāwāt | 'adāla (freedom | equality | justice).

Rev.: in a reeded circle, two lines of Arabic inscriptions - $10 \mid$ pāra (10 | para), a pearl circle below in a wreath in Arabic 1327 (AH 1327), above an Arabic inscription divided by stars - duriba fì | dawla uthmānīya | qustantininya (struck in | Ottoman state | Qustantiniya).

Lit.: Cuhaj 2009b, 2065 no. 760.

Lovecpokladu.cz, no. 5767 (available at: https://www.lovecpokladu.cz/artefakty/nalez/netusim-164868/, 2002).

107. $18 \mathrm{~mm}$, other metrological data are not known, perforation.

South Bohemian Region, April 1, 2012: unpublished

Mehmed V (AH 1327-1336/ 1909-1918 CE), AE 5 para, mint: Qustantiniya, AH 1327/ yr. 3 (= AH 1329/ 1911 CE) - single find.

Obv.: in a reeded circle, sultan's name in the form of tughrā - khān muhammad bin 'abd al-majīd al-muzaffar dā' iman (Khan Mehmed son of Abdulmejid, victorious forever), below two lines of Arabic inscriptions - 3 । sana (3 | the year of), right in Arabic reshād (the True Path Follower), a pearl circle, in the margin - a wreath and an Arabic inscription divided by stars - hurrìya | musāwāt | 'adāla (freedom | equality | justice).

Rev.: in a reeded circle, two lines of Arabic inscriptions - 5 | pāra (5 | para), a pearl circle below in a wreath in Arabic 1327 (AH 1327), above an Arabic inscription divided by stars - duriba fi | dawla uthmānīya | qusțanținìya (struck in | Ottoman state | Qustantiniya).

Lit.: Cuhaj 2009b, p. 2064 no. 759.

Lovecpokladu.cz, no. 4858 (available at: https://www.lovecpokladu.cz/artefakty/nalez/prosim-o-urcenimince-arabska-181275/, 2012).

108. $2.0 \mathrm{~g} ; 14 \mathrm{~mm}$.

North Bohemia, August 27, 2018: unpublished

Mehmed VI (AH 1336-1341/ 1918-1923 CE), AE 40 para, mint: Qustantiniya, AH 1336/ yr. 4 (= AH 1339/1921 CE) - single find.

Obv.: in a reeded circle, sultan's name in the form of tughrā - khān muhammad bin 'abd al-majīd al-muzaffar dā'iman (Khan Mehmed son of Abdulmejid, victorious forever), below two lines of Arabic inscriptions - 4 । sana (4 | the year of), right in Arabic reshād (the True Path Follower), a pearl circle, in the margin - a wreath and an Arabic inscription divided by stars - hurrīya $\mid$ musāwāt | 'adāla (freedom | equality | justice).

Rev.: in a reeded circle, two lines of Arabic inscriptions - 20 | pāra (20 | para), a pearl circle below in a wreath in Arabic 1327 (AH 1327), above an Arabic inscription divided by stars - duriba fì | dawla uthmānīya | qusțanținīya (struck in | Ottoman state | Qustantiniya).

Lit.: Cuhaj 2009b, p. 2069, no. 828.

Lovecpokladu.cz, no. 4111 (available at: https://www.lovecpokladu.cz/artefakty/nalez/mince-178854/, 2018).

109. Metrological data are not known.

\section{JEWELRY JETONS OF BASE METAL}

P̌̌edměřice nad Jizerou (Mladá Boleslav distr.), 2011: Novák and Smělý 2011

Prototype: Mahmud II (AH 1223-1255/ 1808-1839 CE)

mint: Qustantiniya (Istanbul), AV 1/2 çedid mahmudiye, AH 1223/ yr. 28 (= AH 1250/ 1835 CE) - single find. 
Obv.: in a wreath and surrounded by four branches, sultan's name in the form of tughrā - khān mahmūud bin 'abd al-hamìd al-muzaffar dā'iman (Khan Mahmud son of Abdulhamid, victorious forever), right in Arabic 'adli (the Just).

Rev.: in a wreath and surrounded by five branches, four lines of Arabic inscriptions - duriba $28 \mid$ fi $\mid$ qusțanținīya | 1223 (struck 28 | in | Qustantiniya | 1223).

Lit.: Cuhaj 2009a, p. 1192, no. 644 (15 mm, 0.70-0.80 g).

110. $0.393 \mathrm{~g} ; 15.0 / 15.0 \mathrm{~mm}$, perforation, stylized lettering, worn.

\section{South Moravian Region, June 25, 2017: unpublished}

Same - single find.

Lovecpokladu.cz (available at: https://www.lovecpokladu.cz/artefakty/nalez/prosim-o-urceni-mince-142790/, 2017).

111. $15 \mathrm{~mm}$, other metrological data are not known, perforation.

Central Bohemian Region, February 12, 2014: unpublished

Prototype: Mahmud II (AH 1223-1255/ 1808-1839 CE), AV çedid mahmudiye, mint: Qustantiniya, AH 1223/ yr. 28 (= AH 1250/ 1835 CE) - single find

Obv.: in a wreath and surrounded by four branches, sultan's name in the form of tughrā - khān mahmūd bin 'abd al-hamìd al-muzaffar dā'iman (Khan Mahmud son of Abdulhamid, victorious forever), right in Arabic 'adlī (the Just).

Rev.: in a wreath and surrounded by five branches, four lines of Arabic inscriptions - duriba $28 \mid$ fi $\mid$ qusțantinīya | 1223 (struck 28 | in | Qustantiniya | 1223).

Lit.: Cuhaj 2009a, 1192 no. 645.

Lovecpokladu.cz (available at: https://www.lovecpokladu.cz/artefakty/nalez/prosim-o-urceni-34941/, 2014) .

112. Metrological data are not known, perforation (19 $\mathrm{mm}$ based on the photo with scale).

\section{Ústí NAD LABEM Region, February 27, 2014: unpublished}

Same - single find.

Lovecpokladu.cz (available at: https://www.lovecpokladu.cz/artefakty/nalez/zvlastni-predmet-poradite-36294/, 2014).

113. Metrological data are not known, perforation.

BOHEMIA, January 7, 2013: unpublished

Same - single find.

Lovecpokladu.cz (available at: https://www.lovecpokladu.cz/artefakty/nalez/-49743/, 2013).

114. Metrological data are not known, perforation.

\section{Olomouc Region, November 16, 2015: unpublished}

Same - single find.

Lovecpokladu.cz, no. 5077 (available at: https://www.lovecpokladu.cz/artefakty/nalez/medailonek-s-arabpismem-90639/, 2015).

115. $20 \mathrm{~mm}$, other metrological data are not known, perforation, breakage. 
BoHEMIA, June 27, 2017: unpublished

Same - single find

Lovecpokladu.cz (available at: https://www.lovecpokladu.cz/artefakty/nalez/prosim-o-urceni-143307/, 2017).

116. $18 \mathrm{~mm}$, other metrological data are not known, perforation.

Tursкo (Praha-západ distr.), September 6, 2017: unpublished

Same - single find.

117. $0.596 \mathrm{~g} ; 20.0 / 20.3 \mathrm{~mm}, 7 \mathrm{~h}$, perforation, bent flan.

Tab. 3. Ottoman coins found in Bohemia, Moravia and Silesia between 1996 and 2018 (listing based on terminus post quem, continuation of Tab. 2).

\begin{tabular}{|c|c|c|c|c|c|c|}
\hline No. & $\begin{array}{l}\text { Locality/ catalogue } \\
\text { entry }\end{array}$ & $\begin{array}{l}\text { Total number } \\
\text { of coins }\end{array}$ & \begin{tabular}{|l|} 
Ottoman \\
coins, \\
dating (CE)
\end{tabular} & Mint & \begin{tabular}{|l|} 
Terminus \\
post quem \\
(CE)
\end{tabular} & $\begin{array}{l}\text { Date of discovery/ } \\
\text { literature }\end{array}$ \\
\hline 47. & \begin{tabular}{|l|} 
South Moravian \\
Region/ 027
\end{tabular} & $\begin{array}{l}\text { SF (Single } \\
\text { find) } 1 \mathrm{AR}\end{array}$ & \begin{tabular}{|l}
$1 \mathrm{AR}$, \\
$1360-1389$
\end{tabular} & - & after 1389 & $\begin{array}{l}\text { August 27, 2017, } \\
\text { unpublished }\end{array}$ \\
\hline 48. & \begin{tabular}{|l|} 
Bělá pod Bezdězem \\
(Mladá Boleslav \\
distr.)/ 029
\end{tabular} & SF $1+1 \mathrm{AR}$ & \begin{tabular}{|l|}
$1 \mathrm{AR}$, \\
$1481-1512$
\end{tabular} & Nowar & after 1512 & $\begin{array}{l}\text { 2015/ Novák and } \\
\text { Smíśek } 2015\end{array}$ \\
\hline 49. & $\begin{array}{l}\text { Český Krumlov/ } \\
032\end{array}$ & SF 1 AR & \begin{tabular}{|l|}
$1 \mathrm{AR}$, \\
$1512-1520$
\end{tabular} & Nowar & after 1520 & $\begin{array}{l}\text { 2010/ Militký and } \\
\text { Novák } 2010\end{array}$ \\
\hline 50. & Plzeň Region/ 003 & SF 1 AV & $\begin{array}{l}\mathrm{AV} \\
1512-1520\end{array}$ & Halab & after 1520 & 2017, unpublished \\
\hline 51. & \begin{tabular}{|l} 
Ivančice (Brno- \\
venkov distr.)/ 028, \\
030-031
\end{tabular} & $\begin{array}{l}\mathrm{H} \text { (Hoard) } 3 \\
\mathrm{AR}\end{array}$ & $\begin{array}{l}\text { 3 AR, 1422, } \\
1481-1512 \\
1512-1520\end{array}$ & $\begin{array}{l}\text { 1422/ Edirne, } \\
1481-1512 / \\
\text { Edirne, 1512- } \\
1520 / \text { - }\end{array}$ & after 1520 & 2010/ Novák 2011 \\
\hline 52. & Olomouc/ 033 & $\begin{array}{l}\text { SF 1 AR } \\
\text { (plated) }\end{array}$ & $\begin{array}{l}\text { AR } \\
\text { (plated), } \\
1512-1520\end{array}$ & Qustantiniya & after 1520 & 2014, unpublished \\
\hline 53. & $\begin{array}{l}\text { Central Bohemia/ } \\
034\end{array}$ & SF $1 \mathrm{AR}$ & \begin{tabular}{|l|}
$1 \mathrm{AR}$, \\
$1520-1566$ \\
\end{tabular} & - & after 1566 & 2013, unpublished \\
\hline 54. & \begin{tabular}{|l|} 
Vrchoslavice \\
(Prostějov distr.)/ \\
005 \\
\end{tabular} & $\begin{array}{l}\text { SF 1 AV/AR, } \\
\text { forgery }\end{array}$ & $\begin{array}{l}\mathrm{AV} / \mathrm{AR} \\
1566-1574\end{array}$ & - & after 1574 & $\begin{array}{l}\text { 2010/ Novák and } \\
\text { Videman } 2011\end{array}$ \\
\hline 55. & Praha-Castle/ 007 & SF 1 AV & \begin{tabular}{|l|}
$1 \mathrm{AV}$, \\
$1574-1595$ \\
\end{tabular} & Misr & after 1595 & $\begin{array}{l}\text { 2006/ Frolík and } \\
\text { Novák } 2007\end{array}$ \\
\hline 56. & $\begin{array}{l}\text { Votice (Benešov } \\
\text { distr.)/ } 008\end{array}$ & SF $1 \mathrm{AV}$ & \begin{tabular}{|l}
$1 \mathrm{AV}$, \\
$1574-1595$
\end{tabular} & Misr & after 1595 & $\begin{array}{l}\text { 2010/ Novák and } \\
\text { Procházka } 2010\end{array}$ \\
\hline 57. & $\begin{array}{l}\text { Bohemia, } \\
\text { unspecified/ } 010\end{array}$ & SF $1 \mathrm{AV}$ & $\begin{array}{l}1 \mathrm{AV}, \\
1574-1595\end{array}$ & Misr & after 1595 & 2011, unpublished \\
\hline 58. & \begin{tabular}{|l|} 
Bohemia, \\
unspecified/ 015
\end{tabular} & SF 1 AV & \begin{tabular}{|l|}
$1 \mathrm{AV}$, \\
$1574-1595$ \\
\end{tabular} & Misr & after 1595 & 2017, unpublished \\
\hline 59. & \begin{tabular}{|l|} 
Tvrdonice (Břeclav \\
distr.)/ 009
\end{tabular} & SF 1 AV & \begin{tabular}{|l|}
$1 \mathrm{AV}$, \\
$1574-1595$ \\
\end{tabular} & Misr & after 1595 & 2010/ Novák 2014 \\
\hline 60. & \begin{tabular}{|l} 
Mikulov (Břeclav \\
distr.)/ 035
\end{tabular} & SF $1 \mathrm{AR}$ & \begin{tabular}{|l}
$1 \mathrm{AR}$, \\
$1574-1595$
\end{tabular} & - & after 1595 & 2014, unpublished \\
\hline 61. & $\begin{array}{l}\text { Central Bohemia/ } \\
016\end{array}$ & SF $1 \mathrm{AV}$ & $\begin{array}{ll}1 \mathrm{AV}, \\
1574-1595\end{array}$ & Misr & after 1595 & $\begin{array}{l}\text { April 4, 2018, } \\
\text { unpublished }\end{array}$ \\
\hline
\end{tabular}




\begin{tabular}{|c|c|c|c|c|c|c|}
\hline 62. & $\begin{array}{l}\text { Vysočina Region/ } \\
017\end{array}$ & $\begin{array}{l}\text { SF 1 AV/AE, } \\
\text { forgery }\end{array}$ & $\begin{array}{l}1 \mathrm{AV}, \\
1574-1595\end{array}$ & Misr & after $1595+$ & $\begin{array}{l}\text { November 8, 2018, } \\
\text { unpublished }\end{array}$ \\
\hline 63. & \begin{tabular}{|l} 
South Bohemian \\
Region/ 036
\end{tabular} & SF 1 AR & $\begin{array}{l}1 \mathrm{AR}, \\
1574-1595 \\
\end{array}$ & Sidre Qapisi & after 1595 & $\begin{array}{l}\text { December 26, 2016, } \\
\text { unpublished }\end{array}$ \\
\hline 64. & $\begin{array}{l}\text { Horní Rápotice } \\
\text { (Pelhřrimov distr.)/ } \\
\text { 004, 012-014 }\end{array}$ & $\begin{array}{l}\text { H } 341 \\
\text { AR+AV }\end{array}$ & $\begin{array}{l}4 \mathrm{AV}, \\
1520-1566, \\
1574-1595\end{array}$ & $\begin{array}{l}\text { 1520-1566/ } \\
\text { Sidre Qapisi, } \\
\text { 1574-1595/ } \\
\text { Jazair, } \\
2 \text { Misr }\end{array}$ & after 1595 & 2015, unpublished \\
\hline 65. & Znojmo/ 037 & SF 1 AR & \begin{tabular}{|l|}
$1 \mathrm{AR}$, \\
$1595-1603$ \\
\end{tabular} & - & after 1603 & 2014, unpublished \\
\hline 66. & \begin{tabular}{|l|} 
Mladá Boleslav/ \\
021
\end{tabular} & SF 1 AV & \begin{tabular}{|l|}
$1 \mathrm{AV}$, \\
$1603-1617$ \\
\end{tabular} & Jazair & after 1617 & 2015, unpublished \\
\hline 67. & \begin{tabular}{|l|} 
Dobruška \\
(Rychnov nad \\
Kněžnou distr.)/ \\
022 \\
\end{tabular} & SF $1 \mathrm{AV}$ & $\begin{array}{l}1 \mathrm{AV} \\
1603-1617\end{array}$ & Qustantiniya & after 1617 & 2016, unpublished \\
\hline 68. & \begin{tabular}{|l|} 
Bohemia, \\
unspecified/ 019
\end{tabular} & SF 1 AV & \begin{tabular}{|l|}
$1 \mathrm{AV}$ \\
$1603-1617$ \\
\end{tabular} & Misr & after 1617 & 2011, unpublished \\
\hline 69. & Přerov/ 020 & SF $1 \mathrm{AV}$ & \begin{tabular}{|l|}
$1 \mathrm{AV}$ \\
$1603-1617$ \\
\end{tabular} & Qustantiniya & after 1617 & $\begin{array}{l}\text { 2012/ Schenk and } \\
\text { Mikulík } 2013\end{array}$ \\
\hline 70. & $\begin{array}{l}\text { Central Bohemia/ } \\
023\end{array}$ & SF 1 AV & \begin{tabular}{|l|}
$1 \mathrm{AV}$, \\
$1603-1617$ \\
\end{tabular} & Jazair & after 1617 & $\begin{array}{l}\text { September 24, } \\
2016, \text { unpublished }\end{array}$ \\
\hline 71. & $\begin{array}{l}\text { Louny-Předměstí } \\
\text { (Louny distr.)/ 002, } \\
038\end{array}$ & $\begin{array}{l}\text { SF 1 AV/AE, } \\
\text { forgery + 1 } \\
\text { AR }\end{array}$ & \begin{tabular}{|l|}
$1 \mathrm{AV} / \mathrm{AE}$, \\
forgery \\
$+1 \mathrm{AR}$, \\
$1520-1566$, \\
$1618-1622$ \\
\end{tabular} & $\begin{array}{l}1520-66 /- \\
1618-22 /-\end{array}$ & after 1622 & 2016/ Novák 2017 \\
\hline 72. & $\begin{array}{l}\text { Králíky (Ústí nad } \\
\text { Orlicí distr.)/ 018, } \\
024\end{array}$ & H $60 \mathrm{AV}$ & $\begin{array}{l}2 \mathrm{AV}, \\
1574-1595 \\
1603-1617\end{array}$ & \begin{tabular}{|l}
$1574-1595 /$ \\
Misr, 1603- \\
1617/ Misr
\end{tabular} & \begin{tabular}{|l} 
after \\
beginning \\
of the \\
$1630 \mathrm{~s}$ \\
\end{tabular} & 2018, unpublished \\
\hline 73. & $\begin{array}{l}\text { Janovice u Kravař } \\
\text { (Česká Lípa distr.)/ } \\
001\end{array}$ & $\begin{array}{l}\text { H } 9 \mathrm{AV}+2 \\
\text { AR }\end{array}$ & $\begin{array}{l}\mathrm{AV} \\
1520-1566\end{array}$ & Sidre Qapisi & after 1637 & 2013, unpublished \\
\hline 74. & $\begin{array}{l}\text { Bohemia, } \\
\text { unspecified/ } 025\end{array}$ & $\begin{array}{l}\begin{array}{l}\text { SF 1 AV } \\
\text { (collection?) }\end{array} \\
\end{array}$ & $\begin{array}{l}1 \mathrm{AV} \\
\text { (collection } \\
? \text { ), } \\
1623-1640\end{array}$ & Misr & after 1640 & 2012, unpublished \\
\hline 75. & $\begin{array}{l}\text { Bohemia, } \\
\text { unspecified/ } 039\end{array}$ & SF 1 AR & $\begin{array}{l}\mathrm{AR}, \\
1640-1648\end{array}$ & Qustantiniya & after 1648 & 2018, unpublished \\
\hline 76. & Střední Čechy/ 040 & SF 1 AR & \begin{tabular}{|l|}
$1 \mathrm{AR}$ \\
$1648-1687$
\end{tabular} & - & after 1687 & 2013, unpublished \\
\hline 77. & $\begin{array}{l}\text { Stř́ítež u Jihlavy } \\
\text { (Jihlava distr.)/ } 041\end{array}$ & SF $1 \mathrm{AR}$ & \begin{tabular}{|l}
$1 \mathrm{AR}$, \\
$1648-1687$
\end{tabular} & Misr & after 1687 & 2015, unpublished \\
\hline 78. & \begin{tabular}{|l|}
$\begin{array}{l}\text { Loučka (Vsetín } \\
\text { distr.)/ } 075\end{array}$ \\
\end{tabular} & $\mathrm{H} \times \mathrm{AR}+\mathrm{AE}$ & \begin{tabular}{|l|}
$1 \mathrm{AE}$, \\
$1648-1687$ \\
\end{tabular} & Brusa & after 1687 & 2014, unpublished \\
\hline 79. & $\begin{array}{l}\text { Bohemia, } \\
\text { unspecified/ } 089\end{array}$ & SF $1 \mathrm{AE}$ & $1 \mathrm{AE}, 1688$ & Saray & after 1688 & $\begin{array}{l}\text { November 17, 2015, } \\
\text { unpublished }\end{array}$ \\
\hline 80. & $\begin{array}{l}\text { Náchod Region/ } \\
078\end{array}$ & $\begin{array}{l}\text { H } 1 \mathrm{AE}+\mathrm{x} \\
\mathrm{AE}\end{array}$ & \begin{tabular}{|l|}
$1 \mathrm{AE}$, \\
forgery \\
copying \\
heavy silver \\
coin, 1687- \\
1691 \\
\end{tabular} & Qustantiniya & after 1691 & 2014, unpublished \\
\hline 81. & Mělník/ 080 & SF $1 \mathrm{AE}$ & $\begin{array}{l}1 \mathrm{AE}, 1687- \\
1691\end{array}$ & Qustantiniya & after 1691 & $\begin{array}{l}\text { February 2, 2015, } \\
\text { unpublished }\end{array}$ \\
\hline
\end{tabular}




\begin{tabular}{|c|c|c|c|c|c|c|}
\hline 82. & Třebíčc/ 077 & $\begin{array}{l}\text { SF 1 AE, } \\
\text { contemporary } \\
\text { forgery }\end{array}$ & \begin{tabular}{|l|}
$1 \mathrm{AE}$, \\
contemporary \\
forgery, \\
$1687-1691$ \\
\end{tabular} & Qustantiniya & after 1691 & 2011, unpublished \\
\hline 83. & \begin{tabular}{|l|} 
South Moravian \\
Region/ 079
\end{tabular} & SF $1 \mathrm{AE}$ & $\begin{array}{l}1 \mathrm{AE}, \\
1687-1691\end{array}$ & Qustantiniya & after 1691 & $\begin{array}{l}\text { April 28, 2013, } \\
\text { unpublished }\end{array}$ \\
\hline 84. & \begin{tabular}{|l|} 
South Moravian \\
Region/ 081
\end{tabular} & SF $1 \mathrm{AE}$ & \begin{tabular}{|l}
$\mathrm{AE}$, \\
$1687-1691$
\end{tabular} & Qustantiniya & after 1691 & $\begin{array}{l}\text { January 25, 2016, } \\
\text { unpublished }\end{array}$ \\
\hline 85. & $\begin{array}{l}\text { Bohemia, } \\
\text { unspecified/ } 082\end{array}$ & SF $1 \mathrm{AE}$ & $\begin{array}{l}1 \mathrm{AE}, \\
1687-1691\end{array}$ & Qustantiniya & after 1691 & $\begin{array}{l}\text { August 4, 2016, } \\
\text { unpublished }\end{array}$ \\
\hline 86. & $\begin{array}{l}\text { Moravian-Silesian } \\
\text { Region/ } 083\end{array}$ & SF $1 \mathrm{AE}$ & $\begin{array}{l}1 \mathrm{AE}, \\
1687-1691\end{array}$ & Qustantiniya & after 1691 & $\begin{array}{l}\text { October 14, 2016, } \\
\text { unpublished }\end{array}$ \\
\hline 87. & \begin{tabular}{|l|} 
South Bohemian \\
Region/ 084
\end{tabular} & SF 1 AE & $\begin{array}{l}\mathrm{AE}, \\
1687-1691\end{array}$ & Qustantiniya & after 1691 & $\begin{array}{l}\text { August 15, 2017, } \\
\text { unpublished }\end{array}$ \\
\hline 88. & \begin{tabular}{|l|} 
South Moravian \\
Region/ 085
\end{tabular} & SF 1 AE & $\begin{array}{l}\mathrm{AE}, \\
1687-1691\end{array}$ & Qustantiniya & after 1691 & $\begin{array}{l}\text { September 30, } \\
\text { 2017, unpublished }\end{array}$ \\
\hline 89. & \begin{tabular}{|l|} 
South Moravian \\
Region/ 086
\end{tabular} & SF $1 \mathrm{AE}$ & $\begin{array}{l}1 \mathrm{AE}, \\
1687-1691\end{array}$ & Qustantiniya & after 1691 & $\begin{array}{l}\text { November 12, 2017, } \\
\text { unpublished }\end{array}$ \\
\hline 90. & $\begin{array}{l}\text { Central Bohemian } \\
\text { Region/ } 087\end{array}$ & SF $1 \mathrm{AE}$ & $\begin{array}{l}1 \mathrm{AE}, \\
1687-1691\end{array}$ & Qustantiniya & after 1691 & $\begin{array}{l}\text { March 10, 2018, } \\
\text { unpublished }\end{array}$ \\
\hline 91. & $\begin{array}{l}\text { Central Bohemian } \\
\text { Region/ } 088\end{array}$ & SF $1 \mathrm{AE}$ & $\begin{array}{l}1 \mathrm{AE}, \\
1687-1691\end{array}$ & Qustantiniya & after 1691 & $\begin{array}{l}\text { June 7, 2018, } \\
\text { unpublished }\end{array}$ \\
\hline 93. & $\begin{array}{l}\text { Dobroměřice } \\
\text { (Louny distr.)/ 006, } \\
011\end{array}$ & $\begin{array}{l}\mathrm{H} 6 \mathrm{AV}+6 \\
\mathrm{AR}+\end{array}$ & $\begin{array}{l}2 \mathrm{AV}, \\
1566-1574, \\
1574-1595\end{array}$ & $\begin{array}{l}1566-1574 / \\
\text { Misr, 1574- } \\
\text { 1595/ Misr }\end{array}$ & $\begin{array}{l}17^{\text {th }} \\
\text { century }\end{array}$ & 2013, unpublished \\
\hline 95. & $\begin{array}{l}\text { South Bohemian } \\
\text { Region/ } 042\end{array}$ & SF $1 \mathrm{AR}$ & \begin{tabular}{|l|}
$1 \mathrm{AR}$, \\
$1703-1730$
\end{tabular} & Islambul & after 1730 & $\begin{array}{l}\text { August 1,2018, } \\
\text { unpublished }\end{array}$ \\
\hline 96. & $\begin{array}{l}\text { Moravian-Silesian } \\
\text { Region/ } 043\end{array}$ & SF $1 \mathrm{AR}$ & \begin{tabular}{|l}
$\mathrm{AR}$, \\
$1703-1730$
\end{tabular} & Islambul & after 1730 & $\begin{array}{l}\text { January 1, 2019, } \\
\text { unpublished }\end{array}$ \\
\hline 97. & \begin{tabular}{|l|} 
Central Bohemian \\
Region/ 045
\end{tabular} & SF $1 \mathrm{AR}$ & $1 \mathrm{AR}, 1770$ & \begin{tabular}{|l|} 
Islambul \\
\end{tabular} & after 1770 & $\begin{array}{l}\text { August 31, 2018, } \\
\text { unpublished }\end{array}$ \\
\hline 98. & \begin{tabular}{|l|} 
Mladá Boleslav- \\
Podchlumí/ \\
$048-052$ \\
\end{tabular} & H 5 AR & $5 \mathrm{AR}, 1793$ & 5 Misr & after 1793 & $\begin{array}{l}\text { 2012/ Harušt’́k and } \\
\text { Novák } 2013\end{array}$ \\
\hline 99. & \begin{tabular}{|l|} 
South Moravian \\
Region/ 046
\end{tabular} & SF $1 \mathrm{AR}$ & $1 \mathrm{AR}, 1793$ & \begin{tabular}{|l|} 
Islambul \\
\end{tabular} & after 1793 & $\begin{array}{l}\text { October 10, 2015, } \\
\text { unpublished }\end{array}$ \\
\hline 100. & \begin{tabular}{|l|} 
Jaroměř (Náchod \\
distr.)/ 076
\end{tabular} & $\mathrm{H} 3 \mathrm{AE}$ & \begin{tabular}{|l|}
$1 \mathrm{AE}$, \\
$1648-1687$
\end{tabular} & $\begin{array}{l}\text { Tarabulus } \\
\text { Gharb }\end{array}$ & after 1795 & 2014/ Novák 2015 \\
\hline 101. & $\begin{array}{l}\text { Lysá nad Labem } \\
\text { (Nymburk distr.)/ } \\
047\end{array}$ & SF 1 AR & $1 \mathrm{AR}, 1800$ & \begin{tabular}{|l|} 
Islambul \\
\end{tabular} & after 1800 & $\begin{array}{l}\text { 2011/ Kubík and } \\
\text { Novák } 2011\end{array}$ \\
\hline 102. & $\begin{array}{l}\text { South Moravian } \\
\text { Region/ } 026\end{array}$ & SF $1 \mathrm{AV}$ & $1 \mathrm{AV}, 1818$ & Qustantiniya & after 1818 & $\begin{array}{l}\text { March 8, 2006, } \\
\text { unpublished }\end{array}$ \\
\hline 103. & $\begin{array}{l}\text { Moravian-Silesian } \\
\text { Region/ } 058\end{array}$ & SF $1 \mathrm{AR}$ & $1 \mathrm{AR}, 1829$ & Qustantiniya & after 1829 & $\begin{array}{l}\text { June 4, 2014, } \\
\text { unpublished }\end{array}$ \\
\hline 104. & $\begin{array}{l}\text { Pardubice Region/ } \\
054\end{array}$ & SF $1 \mathrm{AR}$ & $1 \mathrm{AR}, 1833$ & Qustantiniya & after 1833 & \begin{tabular}{|l} 
September 16, \\
2015, unpublished
\end{tabular} \\
\hline 105. & \begin{tabular}{|l|} 
Karlovy Vary \\
Region/ 055
\end{tabular} & SF $1 \mathrm{AR}$ & $1 \mathrm{AR}, 1833$ & Qustantiniya & after 1833 & $\begin{array}{l}\text { January } 8,2013, \\
\text { unpublished }\end{array}$ \\
\hline 106. & $\begin{array}{l}\text { Central Bohemia/ } \\
056\end{array}$ & SF $1 \mathrm{AR}$ & $1 \mathrm{AR}, 1835$ & Qustantiniya & after 1835 & $\begin{array}{l}\text { November 19, } \\
\text { 2016, unpublished }\end{array}$ \\
\hline 107. & $\begin{array}{l}\text { Ústí nad Labem } \\
\text { Region/ } 057\end{array}$ & SF $1 \mathrm{AR}$ & $1 \mathrm{AR}, 1836$ & Qustantiniya & after 1836 & $\begin{array}{l}\text { Feruary 26, 2014, } \\
\text { unpublished }\end{array}$ \\
\hline 108. & $\begin{array}{l}\text { Nakléřov (Ústí nad } \\
\text { Labem distr.)/ 044, } \\
059\end{array}$ & H 2 AR & \begin{tabular}{|l|}
$2 \mathrm{AR}, 1768$ \\
1836
\end{tabular} & $\begin{array}{l}1768 / \text { Islambul, } \\
1836 / \\
\text { Qustantiniya }\end{array}$ & after 1836 & 2011/ Novák 2010 \\
\hline
\end{tabular}




\begin{tabular}{|c|c|c|c|c|c|c|}
\hline 109. & $\begin{array}{l}\text { Central Bohemia/ } \\
053\end{array}$ & SF $1 \mathrm{AR}$ & $1 \mathrm{AR}, 1837$ & Qustantiniya & after 1837 & $\begin{array}{l}\text { May 21, 2017, } \\
\text { unpublished }\end{array}$ \\
\hline 110. & \begin{tabular}{|l|} 
Mikulov (Břeclav \\
distr.)/ 060
\end{tabular} & SF $1 \mathrm{BI}$ & $1 \mathrm{BI}, 1839$ & Qustantiniya & after 1839 & 2013, unpublished \\
\hline 111. & \begin{tabular}{|l|} 
South Moravian \\
Region/ 062
\end{tabular} & SF $1 \mathrm{BI}$ & $1 \mathrm{BI}, 1839$ & Qustantiniya & after 1839 & $\begin{array}{l}\text { May 23, 2013, } \\
\text { unpublished }\end{array}$ \\
\hline 112. & $\begin{array}{l}\text { Central Bohemian } \\
\text { Region/ } 063\end{array}$ & SF $1 \mathrm{BI}$ & $1 \mathrm{BI}, 1839$ & Qustantiniya & after 1839 & $\begin{array}{l}\text { October 20, 2013, } \\
\text { unpublished }\end{array}$ \\
\hline 113. & \begin{tabular}{|l|} 
South Moravian \\
Region/ 061, 064
\end{tabular} & SF 2 BI & $\begin{array}{l}2 \mathrm{BI}, 1839, \\
1840\end{array}$ & $\begin{array}{l}1839 / \\
\text { Qustantiniya, } \\
1840 / \\
\text { Qustantiniya } \\
\end{array}$ & after 1840 & $\begin{array}{l}\text { January 7, 2013, } \\
\text { unpublished }\end{array}$ \\
\hline 114. & $\begin{array}{l}\text { Moravská } \\
\text { Třebová/ } 065\end{array}$ & SF $1 \mathrm{BI}$ & $1 \mathrm{BI}, 1840$ & Qustantiniya & after 1840 & 2018, unpublished \\
\hline 115. & $\begin{array}{l}\text { Central Bohemia/ } \\
090\end{array}$ & SF $1 \mathrm{AE}$ & $1 \mathrm{AE}, 1857$ & Qustantiniya & after 1857 & 2014, unpublished \\
\hline 116. & \begin{tabular}{|l|}
$\begin{array}{l}\text { Moravia, } \\
\text { unspecified/ } 091\end{array}$ \\
\end{tabular} & SF $1 \mathrm{AE}$ & $1 \mathrm{AE}, 1858$ & Qustantiniya & after 1858 & $\begin{array}{l}\text { June 26, 2009, } \\
\text { unpublished }\end{array}$ \\
\hline 117. & \begin{tabular}{|l|} 
South Bohemian \\
Region/ 095
\end{tabular} & SF $1 \mathrm{AE}$ & $1 \mathrm{AE}, 1861$ & Qustantiniya & after 1861 & $\begin{array}{l}\text { September 19, } \\
\text { 2018, unpublished }\end{array}$ \\
\hline 118. & $\begin{array}{l}\text { Bohemian, } \\
\text { unspecified/ } 092\end{array}$ & SF $1 \mathrm{AE}$ & $1 \mathrm{AE}, 1864$ & Qustantiniya & after 1864 & $\begin{array}{l}\text { December 27, 2018, } \\
\text { unpublished }\end{array}$ \\
\hline 119. & \begin{tabular}{|l|} 
Ústí nad Labem \\
Region/ 093
\end{tabular} & SF $1 \mathrm{AE}$ & $1 \mathrm{AE}, 1864$ & Qustantiniya & after 1864 & $\begin{array}{l}\text { August 17, 2009, } \\
\text { unpublished }\end{array}$ \\
\hline 120. & \begin{tabular}{|l} 
Karlovy Vary \\
Region/ 094 \\
\end{tabular} & SF $1 \mathrm{AE}$ & $1 \mathrm{AE}, 1864$ & Qustantiniya & after 1864 & $\begin{array}{l}\text { April 28, 2017, } \\
\text { unpublished }\end{array}$ \\
\hline 121. & $\begin{array}{l}\text { Vysočina Region/ } \\
096\end{array}$ & SF $1 \mathrm{AE}$ & $1 \mathrm{AE}, 1864$ & Qustantiniya & after 1864 & $\begin{array}{l}\text { March 18, 2012, } \\
\text { unpublished }\end{array}$ \\
\hline 122. & \begin{tabular}{|l|} 
Moravian-Silesian \\
Region/ 097
\end{tabular} & SF $1 \mathrm{AE}$ & $1 \mathrm{AE}, 1864$ & Qustantiniya & after 1864 & $\begin{array}{l}\text { March 2, 2013, } \\
\text { unpublished }\end{array}$ \\
\hline 123. & $\begin{array}{l}\text { Olomouc Region/ } \\
098\end{array}$ & SF $1 \mathrm{AE}$ & $1 \mathrm{AE}, 1864$ & Qustantiniya & after 1864 & $\begin{array}{l}\text { October 14, 2017, } \\
\text { unpublished }\end{array}$ \\
\hline 124. & $\begin{array}{l}\text { Bohemia, } \\
\text { unspecified/ } 099\end{array}$ & SF $1 \mathrm{AE}$ & $1 \mathrm{AE}, 1864$ & Misr & after 1864 & $\begin{array}{l}\text { December 3, 2014, } \\
\text { unpublished }\end{array}$ \\
\hline 125. & \begin{tabular}{|l|} 
Karlovy Vary \\
Region/ 103 \\
\end{tabular} & SF $1 \mathrm{AE}$ & $1 \mathrm{AE}, 1864$ & Qustantiniya & after 1864 & $\begin{array}{l}\text { July } 17,2018, \\
\text { unpublished }\end{array}$ \\
\hline 126. & \begin{tabular}{|l|} 
South Moravian \\
Region/ 100
\end{tabular} & SF $1 \mathrm{AE}$ & $1 \mathrm{AE}, 1865$ & Misr & after 1865 & $\begin{array}{l}\text { January 19, 2013, } \\
\text { unpublished }\end{array}$ \\
\hline 127. & $\begin{array}{l}\text { Central Bohemian } \\
\text { Region/ } 101\end{array}$ & SF $1 \mathrm{AE}$ & $1 \mathrm{AE}, 1865$ & Misr & after 1865 & $\begin{array}{l}\text { June } 18,2017 \text {, } \\
\text { unpublished }\end{array}$ \\
\hline 128. & \begin{tabular}{|l|} 
South Moravian \\
Region/ 102
\end{tabular} & SF $1 \mathrm{AE}$ & $1 \mathrm{AE}, 1866$ & Misr & after 1866 & $\begin{array}{l}\text { February 23, 2006, } \\
\text { unpublished }\end{array}$ \\
\hline 129. & Plzeň Region/ 067 & SF 1 AR & $1 \mathrm{AR}, 1870$ & Qustantiniya & after 1870 & $\begin{array}{l}\text { September 9, 2016, } \\
\text { unpublished }\end{array}$ \\
\hline 130. & $\begin{array}{l}\text { Olomouc Region/ } \\
066\end{array}$ & SF 1 AR & \begin{tabular}{|l|}
$1 \mathrm{AR}$ \\
$1861-1876$
\end{tabular} & Qustantiniya & after 1876 & $\begin{array}{l}\text { November 20,2012, } \\
\text { unpublished }\end{array}$ \\
\hline 131. & \begin{tabular}{|l|} 
Újezdec (Svitavy \\
distr.)/ 068
\end{tabular} & \begin{tabular}{|l|} 
SF $1 \mathrm{AR}+$ \\
$8 \mathrm{AE}$ \\
\end{tabular} & $1 \mathrm{AR}, 1876$ & Qustantiniya & after 1876 & $\begin{array}{l}\text { 2012/ Hrubeš and } \\
\text { Novák } 2011\end{array}$ \\
\hline 132. & $\begin{array}{l}\text { Central Bohemia/ } \\
071\end{array}$ & SF 1 AR & $1 \mathrm{AR}, 1884$ & Qustantiniya & after 1884 & $\begin{array}{l}\text { August 21, 2017, } \\
\text { unpublished }\end{array}$ \\
\hline 133. & $\begin{array}{l}\text { South Bohemian } \\
\text { Region/ } 072\end{array}$ & SF $1 \mathrm{AR}$ & $1 \mathrm{AR}, 1891$ & Qustantiniya & after 1891 & $\begin{array}{l}\text { November 20, 2017, } \\
\text { unpublished }\end{array}$ \\
\hline 134. & $\begin{array}{l}\text { Central Bohemian } \\
\text { Region/ } 069\end{array}$ & SF $1 \mathrm{AR}$ & $1 \mathrm{AR}, 1898$ & Qustantiniya & after 1898 & $\begin{array}{l}\text { August 27, 2017, } \\
\text { unpublished }\end{array}$ \\
\hline
\end{tabular}




\begin{tabular}{|c|c|c|c|c|c|c|}
\hline 135. & \begin{tabular}{|l|} 
Central Bohemian \\
Region/ 073
\end{tabular} & SF $1 \mathrm{AR}$ & $1 \mathrm{AR}, 1898$ & Qustantiniya & after 1898 & $\begin{array}{l}\text { September 3, 2018, } \\
\text { unpublished }\end{array}$ \\
\hline 136. & $\begin{array}{l}\text { Bohemia, } \\
\text { unspecified/ } 074\end{array}$ & SF $1 \mathrm{AR}$ & $1 \mathrm{AR}, 1900$ & Qustantiniya & after 1900 & $\begin{array}{l}\text { October 17, 2014, } \\
\text { unpublished }\end{array}$ \\
\hline 137. & $\begin{array}{l}\text { Central Bohemian } \\
\text { Region/ } 070\end{array}$ & SF $1 \mathrm{AR}$ & $1 \mathrm{AR}, 1901$ & Qustantiniya & after 1901 & $\begin{array}{l}\text { April 12, 2018, } \\
\text { unpublished }\end{array}$ \\
\hline 138. & \begin{tabular}{|l|} 
South Moravian \\
Region/ 107
\end{tabular} & SF $1 \mathrm{AE}$ & $1 \mathrm{AE}, 1910$ & Qustantiniya & after 1910 & $\begin{array}{l}\text { December 8, 2002, } \\
\text { unpublished }\end{array}$ \\
\hline 139. & $\begin{array}{l}\text { Karlovy Vary } \\
\text { Region/ } 104\end{array}$ & SF $1 \mathrm{AE}$ & $1 \mathrm{AE}, 1911$ & Qustantiniya & after 1911 & $\begin{array}{l}\text { January 20, 2013, } \\
\text { unpublished }\end{array}$ \\
\hline 140. & $\begin{array}{l}\text { Bohemia, } \\
\text { unspecified/ } 105\end{array}$ & SF $1 \mathrm{AE}$ & $1 \mathrm{AE}, 1911$ & Qustantiniya & after 1911 & $\begin{array}{l}\text { July } 27,2016 \text {, } \\
\text { unpublished }\end{array}$ \\
\hline 141. & \begin{tabular}{|l|} 
South Bohemian \\
Region/ 108
\end{tabular} & SF $1 \mathrm{AE}$ & $1 \mathrm{AE}, 1911$ & Qustantiniya & after 1911 & $\begin{array}{l}\text { April 1, 2012, } \\
\text { unpublished }\end{array}$ \\
\hline 142. & \begin{tabular}{|l|} 
South Moravian \\
Region/ 106
\end{tabular} & SF $1 \mathrm{AE}$ & $1 \mathrm{AE}, 1913$ & Qustantiniya & after 1913 & $\begin{array}{l}\text { July } 27,2013 \text {, } \\
\text { unpublished }\end{array}$ \\
\hline 143. & $\begin{array}{l}\text { North Bohemia/ } \\
109\end{array}$ & SF 1 AE & $1 \mathrm{AE}, 1921$ & Qustantiniya & after 1921 & $\begin{array}{l}\text { August 27, 2018, } \\
\text { unpublished }\end{array}$ \\
\hline
\end{tabular}

\begin{tabular}{|c|l|l|l|l|l|l|}
\hline 1J. & $\begin{array}{l}\text { Předměřice nad } \\
\text { Jizerou (Mladá } \\
\text { Boleslav distr.)/ } 110\end{array}$ & $\begin{array}{l}\text { SF 1 AV/AE, } \\
\text { jeton }\end{array}$ & $\begin{array}{l}1 \mathrm{AV} / \mathrm{AE}, \\
1835\end{array}$ & Qustantiniya & $\begin{array}{l}\text { (after } \\
1835)\end{array}$ & $\begin{array}{l}\text { 2011/ Novák and } \\
\text { Smělý } 2011\end{array}$ \\
\hline 2J. & $\begin{array}{l}\text { South Moravian } \\
\text { Region/ } 111\end{array}$ & $\begin{array}{l}\text { SF 1 AV/AE, } \\
\text { jeton }\end{array}$ & $\begin{array}{l}1 \mathrm{AV} / \mathrm{AE}, \\
1835\end{array}$ & Qustantiniya & $\begin{array}{l}\text { (after } \\
1835)\end{array}$ & $\begin{array}{l}\text { June 25, 2017, } \\
\text { unpublished }\end{array}$ \\
\hline 3J. & $\begin{array}{l}\text { Central Bohemian } \\
\text { Region/ } 112\end{array}$ & $\begin{array}{l}\text { SF 1 AV/AE, } \\
\text { jeton }\end{array}$ & $\begin{array}{l}1 \mathrm{AV} / \mathrm{AE}, \\
1835\end{array}$ & Qustantiniya & $\begin{array}{l}\text { (after } \\
1835)\end{array}$ & $\begin{array}{l}\text { February 12, 2014, } \\
\text { unpublished }\end{array}$ \\
\hline 4J. & $\begin{array}{l}\text { Ústí nad Labem } \\
\text { Region/ } 113\end{array}$ & $\begin{array}{l}\text { SF 1 AV/AE, } \\
\text { jeton }\end{array}$ & $\begin{array}{l}1 \mathrm{AV} / \mathrm{AE}, \\
1835\end{array}$ & Qustantiniya & $\begin{array}{l}\text { after } \\
1835)\end{array}$ & $\begin{array}{l}\text { February 27, 2014, } \\
\text { unpublished }\end{array}$ \\
\hline 5J. & $\begin{array}{l}\text { Bohemia, } \\
\text { unspecified/ } 114\end{array}$ & $\begin{array}{l}\text { SF 1 AV/AE, } \\
\text { jeton }\end{array}$ & $\begin{array}{l}1 \mathrm{AV} / \mathrm{AE}, \\
1835\end{array}$ & Qustantiniya & $\begin{array}{l}\text { (after } \\
1835)\end{array}$ & $\begin{array}{l}\text { January 7, 2017, } \\
\text { unpublished }\end{array}$ \\
\hline 6J. & $\begin{array}{l}\text { Olomouc Region/ } \\
115\end{array}$ & $\begin{array}{l}\text { SF 1 AV/AE, } \\
\text { jeton }\end{array}$ & $\begin{array}{l}1 \mathrm{AV} / \mathrm{AE}, \\
1835\end{array}$ & Qustantiniya & $\begin{array}{l}\text { (after } \\
1835)\end{array}$ & $\begin{array}{l}\text { November 16, 2015, } \\
\text { unpublished }\end{array}$ \\
\hline 7J. & $\begin{array}{l}\text { Bohemia, } \\
\text { unspecified/ } 116\end{array}$ & $\begin{array}{l}\text { SF 1 AV/AE, } \\
\text { jeton }\end{array}$ & $\begin{array}{l}1 \mathrm{AV} / \mathrm{AE}, \\
1835\end{array}$ & Qustantiniya & $\begin{array}{l}\text { (after } \\
1835)\end{array}$ & $\begin{array}{l}\text { June 27, 2017, } \\
\text { unpublished }\end{array}$ \\
\hline 8J. & $\begin{array}{l}\text { Tursko (Praha }- \\
\text { západ distr.)/ } 117\end{array}$ & $\begin{array}{l}\text { SF 1 AV/AE, } \\
\text { jeton }\end{array}$ & $\begin{array}{l}1 \mathrm{AV} / \mathrm{AE}, \\
1835\end{array}$ & Qustantiniya & $\begin{array}{l}\text { (after } \\
1835)\end{array}$ & $\begin{array}{l}\text { September 6, 2017, } \\
\text { unpublished }\end{array}$ \\
\hline
\end{tabular}

\section{Summary}

Up until 2018, some 151 finds of Ottoman coins, their forgeries, and decorative copies have been registered in the territory of the Czech Republic. These coins have come to the mentioned territory via the Ottoman European expansion since the $16^{\text {th }}$ century, and their flow reached its peak in the $17^{\text {th }}$ century. This phenomenon is connected with the Thirty Years War in Bohemia (partly in Moravia and in Silesia), but in south and central Moravia, it is explained by the direct military impact of the Ottoman element. The latest summarization of the discovered coins ${ }^{13}$ containing material registered up to 1996, and the newly found pieces in 1996-2018 bring a new view in the distribution and interpretation of Ottoman coins in the Czech Republic, mainly in the $18^{\text {th }}$ and $19^{\text {th }}$ 
centuries. In 1996, the Ottoman coins of the $16^{\text {th }}$ and $17^{\text {th }}$ centuries seemed to dominate absolutely in finds covering Bohemia, Moravia, and Silesia. The vast majority of finds (34 hoards with the Ottoman coins as admixture) were of a group character and were evidently connected with the Thirty Years War (1618-1648), and the period closely following it. The gold Ottoman coins - around 300 pieces - are basically represented in the mentioned territory by specimens struck from 1520 to 1640 . They served relatively long in circulation, and they show a significant territorial diversity of origin, a high level of wear, and attempts of cutting into pieces and testing. The newly documented Ottoman coins in the territory of Bohemia, Moravia, and Silesia from 1996 to 2018 significantly enrich our knowledge about the appearance of these coins in the territory of the Czech Republic - the quantity of the registered material increased three times (117 pieces) compared to the previous period, and single finds totally dominate (6 hoards and 100 single finds), gold coins represent the clear minority of the corpus (26 pieces among 117 pieces in total), and quite a substantive quantity of coins (51 pieces) belong to issues produced after 1800. Historically later silver and copper coins can point to the period of the Napoleonic Wars or to the modern Austro-Hungarian period with its Balkan overlaps. In the case of Bohemia, the copper coins evidently represent a secondary import. Decorative jetons can point to the local production for export (Jablonec) or to memorabilia imported from the Balkans.

In general, the Ottoman coins are regularly dispersed all over the Bohemian territory, and they are connected with the following phenomena: the Thirty Years War, the Napoleonic Wars, and the Austro-Hungarian contacts in the Balkans. The same could basically be said about Moravia northwards behind the line Jihlava - Brno Přerov - Vsetín. To the south of the mentioned line, the finds can be clearly connected directly with Ottoman military activities.

Among the gold Ottoman coins registered up to 1996, pieces struck in Istanbul (Qustantiniya), Egypt (Misr), Baghdad, Damascus, Aleppo (Halab), Alger, and Sidre Qapisi (Thessaloniki vilayet, continental Greece) are the most frequent. The following mints are regarded as rare for the gold issues: Amasiya (Siwas vilayet, Anatolia), Amid (Diyarbakr vilayet, Armenia), Hanja (today Gianja, Azerbaijan), Saqiz (Scio Island in the Greek Archipelago), Srebrenitcha (Srebrenica, Bosnia), Tarabulus Gharb (Tripoli, Libya), and Tuqat (Greek Eudoxia, north Cappadocia). The rarest mint for silver is represented by Tchaynitcha (south Bosnia). Istanbul (Qustantiniya, Islambul) evidently dominates among the Ottoman mints for the coins found between 1996 and 2018. Misr (Egypt, Cairo) is the second most frequent mint. In the case of gold coins, the following mints seem to be interesting: Halab (Aleppo, Syria), Jazair (Alger), and Sidre Qapisi (Thessaloniki vilayet, continental Greece). Among the silver issues, Edirne and Nowar (Novo Brdo, Kosovo) attracts special attention. Sometimes, relatively rare mints appear among the Ottoman earlier copper: Tarabulus Gharb (Tripoli, Libya), Brusa (noth-west Anatolia), and Saray (Sarajevo, Bosnia). In the case of gold issues and larger silver pieces, big central mints dominate (Istanbul, Misr), in the case of smaller and earlier silver denominations, as well as in the case of copper coins, a larger territorial diversity with an inclination to the Balkans can be seen.

From a technical point of view, perforated pieces are worth noting (all decorative jetons have been pierced). This kind of modification can give evidence of a secondary (decorative) use of the coins in their target (final) destination. The coins with pendant or traces of it plus pieces modified for buttons are of the same category. It is clear that 
the Ottoman coins found in the territory of the Czech Republic and produced before 1700 are more or less of the thesaurization character, and in other cases, their exotic aesthetic style (i.e., Arabic calligraphy) was given priority in a different historical era. Forgeries of the Ottoman coins found in the territory of the Czech Republic can be seen as a special category. The gold plated forgeries copying gold coins represent the increased contemporary demand for gold, and they are with the highest probability of a local (central European) provenance. The silver plated pieces and copper imitations could be regarded as authentic Ottoman forgeries coming to the mentioned territory, which have accidentally been lost there.

\section{Literature:}

Adámek, K. (1900-1901). Město Skuč. Památky archeologické, 19, p. 295.

Album, S. (2011). Checklist of Islamic Coins, $3^{\text {rd }}$ ed. Santa Rosa, CA: Stephen Album Rare Coins.

Artuk, I. and Artuk, C. (1974). İstanbul arkeoloji müzeleri teşhirdeki islami sikkeler kataloğu II. İstanbul: TC Milli Egitim Bakanligi Eski Eserler ve Müzeler Genel Müdürlügü.

Augst, B. (1958). Osmánské altuny z nálezu v lese Koblížku u Kamenice n. L. Numismatické listy, 13, pp. 92-96.

Chumchal, M. (1994). Nález mincí v Přerově v roce 1923. In: Z. Gardavský, ed., Minulost Přerovska 1993. Sborník prací $z$ dějin přerovského regionu. Přerov: Muzeum Komenského v Př̀rově, pp. 129-146.

Cuhaj, G., ed. (2009a). Standard Catalog of World Coins. 1801-1900, $6^{\text {th }}$ ed. Iola, WI: Krause Publications.

Cuhaj, G., ed. (2009b). Standard Catalog of World Coins. 1901-2000, $6^{\text {th }}$ ed. Iola, WI: Krause Publications.

Čapka, F. (1998). Dějiny zemí Koruny české v datech. Praha: Nakladatelství Libri.

Damali, A. (2010/1). History of Ottoman Coins, Vol. 1. İstanbul: Nilüfer Damali Egitim.

Damali, A. (2010/2). History of Ottoman Coins, Vol. 2. İstanbul: Nilüfer Damali Egitim.

Damali, A. (2011/3). History of Ottoman Coins, Vol. 3. İstanbul: Nilüfer Damali Egitim.

Damali, A. (2011/4). History of Ottoman Coins, Vol. 4. İstanbul: Nilüfer Damali Egitim.

Damali, A. (2012). History of Ottoman Coins, Vol. 5. İstanbul: Nilüfer Damali Egitim.

Detektorweb.cz, (2003-). [online] Available at www.detektorweb.cz [Accessed 2011].

Fiala, E. (1922). Zlatý poklad. Koblížek u Kamenice. Věstník Numismatické společnosti československé, 4, pp. 170-171.

Frolik, J. and Novák, V. (2007). Nález turecké zlaté mince v Praze na Hradčanech. Numismatický sbornik, 22, pp. 260-266.

Ghalib, I. (1890). Numismatique ottomane. Constantinople: Mihran Matbaas1. 
Harušták, M. and Novák, V. (2013). Nález stříbrných osmanských mincí sultána Salíma III. z Mladé Boleslavi-Podchlumí. Numismatický sborník, 27(1), pp. 134-136.

Hrubeš, M. and Novák, V. (2011). Nález stříbrného piastru osmanského sultána Muráda V. u obce Újezdec (okr. Svitavy). Numismatický sbornik, 26(2), pp. 314-315.

Kabaklarli, N. (1998). Copper Coins of Ottoman Empire. 1299-1808. İstanbul: Usaklilar Egitim Kultur Vakfi Yayinlari.

Krause, Ch. and Mishler, C. (1997). Standard Catalog of World Coins. $18^{\text {th }}$ Century Edition 1701-1800, $2^{\text {nd }}$ ed. Iola, WI: KP Books.

Kubík, M. and Novák, V. (2011). Nález stříbrné mince osmanského sultána Salíma III. z Lysé nad Labem (okr. Nymburk). Numismatický sborník, 26(1), pp. 144-146.

Lane-Poole, S. (1883). Catalogue of Oriental Coins in the British Museum, Vol. VIII. The Coins of the Turks in the British Museum. London: British Museum.

Lovecpokladu.cz (2006-). [online] Available at: www.lovecpokladu.cz [Accessed 20122019].

Militký, J. and Novák, V. (2010). Nález osmanské stříbrné mince Salíma I. z Českého Krumlova. Numismatický sborník, 25, pp. 170-172.

Mitchiner, M. (1977). Oriental Coins and their Values. The World of Islam. London: Hawkins Publications.

Nálezy III/1 = Nemeškal, L. (1957). České, moravské a slezské nálezy mincí údobí tolarového. In: E. Nohejlová-Prátová, ed., Nálezy mincí v Čechách, na Moravě a ve Slezsku, Dîl III/1. Praha: Československá akademie věd, pp. 7-214.

Nálezy = E. Nohejlová-Prátová, ed. (1955-1958). Nálezy mincí v Čechách, na Moravě a ve Slezsku, Dîl I-IV. Praha: Československá akademie věd.

Nemeškal, L. (1958). Nálezy z údobí třicetileté války v Drhovech, okr. Dobříšs. Numismatický sbornik, 5, pp. 353-354.

Novák, V. (1996). Find of a Piaster of the Ottoman Sultan Mustafa II in Prague-Suchdol Quarter. Archiv Orientální, 64, pp. 395-398.

Novák, V. (2000). Characteristic Features of the Ottoman Coinage/Caratteristiche generali della monetazione otomana. In: N. Vismara, ed., Monete di Piuro, 7. elementi per una ricerca. Chiavenna: Museo della Valchiavenna, pp. 51-56, 60.

Novák, V. (2006). Struktura nálezů tureckých mincí v Českých zemích a na Slovensku, jejich interpretace $\mathrm{s}$ přihlédnutím $\mathrm{k}$ nově publikovanému materiálu. Numismatický sbornik, 21, pp. 181-189.

Novák, V. (2010). Nález dvou stř̌ibrných osmanských mincí od Nakléřova (okr. Ústí nad Labem). Numismatický sborník, 25, pp. 186-188.

Novák, V. (2011). Nové nálezy tureckých mincí z území Čech, Moravy a Slovenska. In: Orientalia Antiqua Nova. XI. Plzeň: Západočeská univerzita, pp. 101-103.

Novák, V. (2014). Nález osmanské zlaté mince Muráda III. z Tvrdonic (okr. Břeclav). Numismatický sborník, 28 (2), pp. 287-290. 
Novák, V. (2015). Nález jedné osmanské a tř́i čínských mincí z Jaroměře (okr. Náchod). Numismatický sborník, 29(1), pp. 120-124.

Novák, V. (2017). Fragment falsa osmanské zlaté mince nalezený v blízkosti železniční zastávky Louny předměstí. K fenoménu falsátorství osmanských zlatých sultání za třicetileté války. Numismatické listy, 72, pp. 155-168.

Novák, V. and Procházka, Z. (2010). Nález zlaté osmanské mince Muráda III. z Votic (okr. Benešov). Numismatický sborník, 25, pp. 183-185.

Novák, V. and Smělý, T. (2011). Nález fantazijního osmanského žetonu z Předměřic nad Jizerou (okr. Mladá Boleslav). Numismatický sborník, 26(1), pp. 146-148.

Novák, V. and Smíšek, K. (2015). Nález osmanské stříbrné mince sultána Bájazída II. a stříbrné benátské ražby druhé poloviny 16. století z Bělé pod Bezdězem (okr. Mladá Boleslav). Numismatický sborník, 29(1), pp. 117-119.

Novák, V. and Videman, J. (2011). Nález zlomku osmanské stř́ibrné pozlacené mince od Vrchoslavic (okr. Prostějov). Numismatické listy, 66(1), pp. 36-40.

Østrup, J. (1938). Catalogue des monnaies arabes et turques du Cabinet royal des médailles du Musée national de Copenhague. Copenhague: Levin \& Munksgaard.

Pere, N. (1968). Coins of the Ottoman Empire. İstanbul: Yap1 ve Kredi Bankası.

Petrtyl, J. (1955). Nálezy mincí na Hlinecku. Numismatický sbornik, 2, p. 189.

Schaendlinger, A. (1973). Osmanische Numismatik. Braunschweig: Klinkhardt und Biermann.

Schenk, Z. and Mikulik, J. (2013). Přerov - Na Marku. Archeologický odkryv sboru a domu se školou jednoty bratrské. In: J. Lapáček, ed., Sborník Státního okresního archivu Přerov. Přerov: Zemský archiv v Opavě, pp. 5-24.

Skutil, J. and Malá, A. (1958). Soupis středo- a novověkých nálezů mincí na Moravě. Numismatický sbornik, 5, p. 332.

Srećković, S. (1999). Akches, Vol. 1. Belgrade: S. Srećković

Srećković, S. (2000). Akches, Vol. 2. Belgrade: S. Srećković.

Srećković, S. (2005). Akches, Vol. 4. Belgrade: S. Srećković.

Sultan, J. (1977). Coins of the Ottoman Empire and the Turkish Republic. Thousand Oaks, CA: B \& R Publishers.

Štěpková, J. (1957). Nález u Chvalkovic (okres Jaroměř). Numismatický sbornike, 4, pp. 213-214.

Štěpková, J. (1963). Coins of the Osmanli Sultans in the Coin-Hoards found on Czechoslovak Territory. Annals of the Náprstek Museum, 2, pp. 141-192.

Štěpková, J. (1968). Islámské mince v nálezech ze Slovenska. Numismatický sbornik, 10, pp. 278-282.

Tauer, F. (1984). Svět islámu. Praha: Vyšehrad.

Zeno.ru = Zeno.ru - Oriental Coins Database, (2002-). [online] Available at: www.zeno.ru. 
Pl. 1
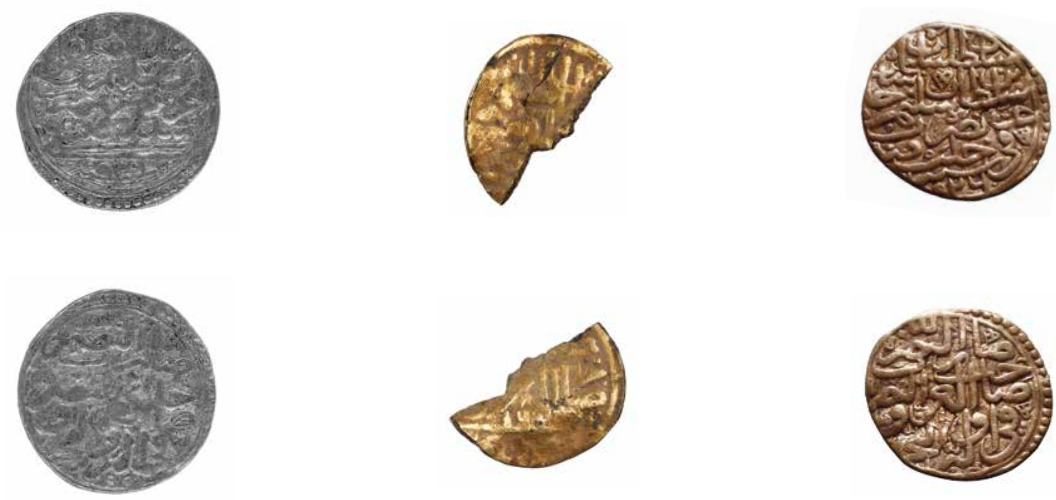

001

002

003
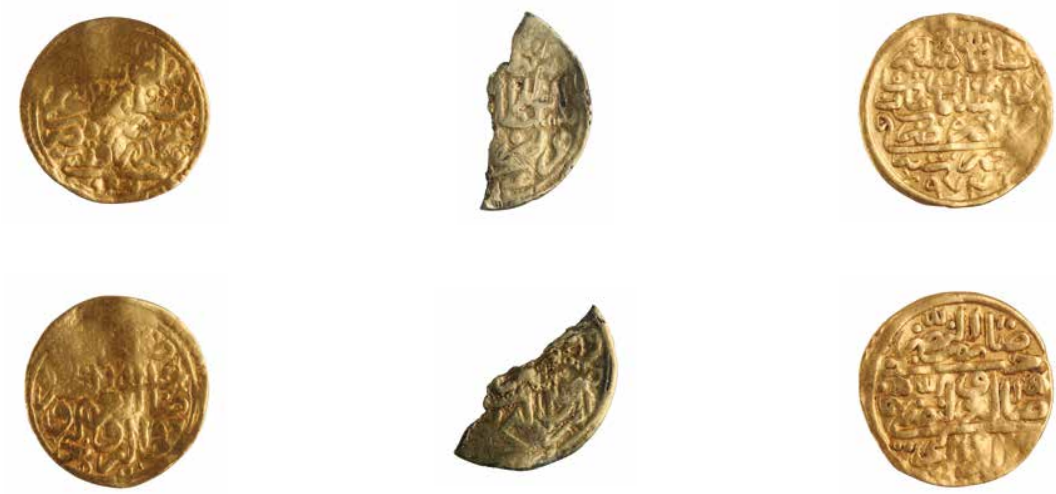

004

005

006
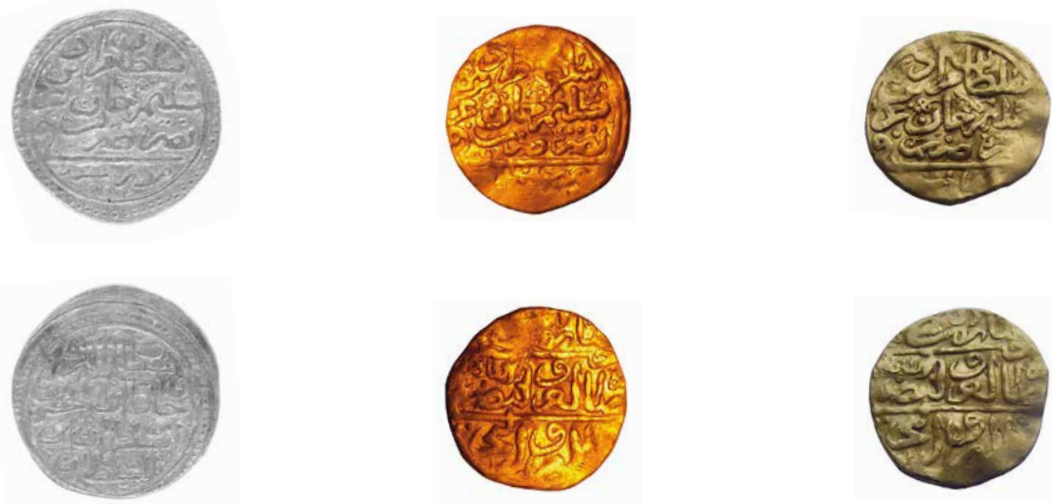

007

008

009 
Pl. 2
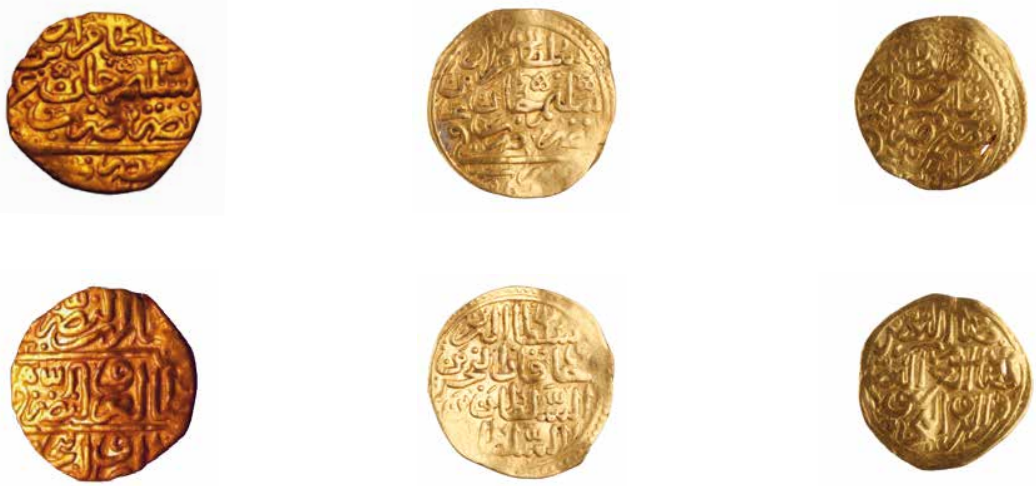

010

011

012
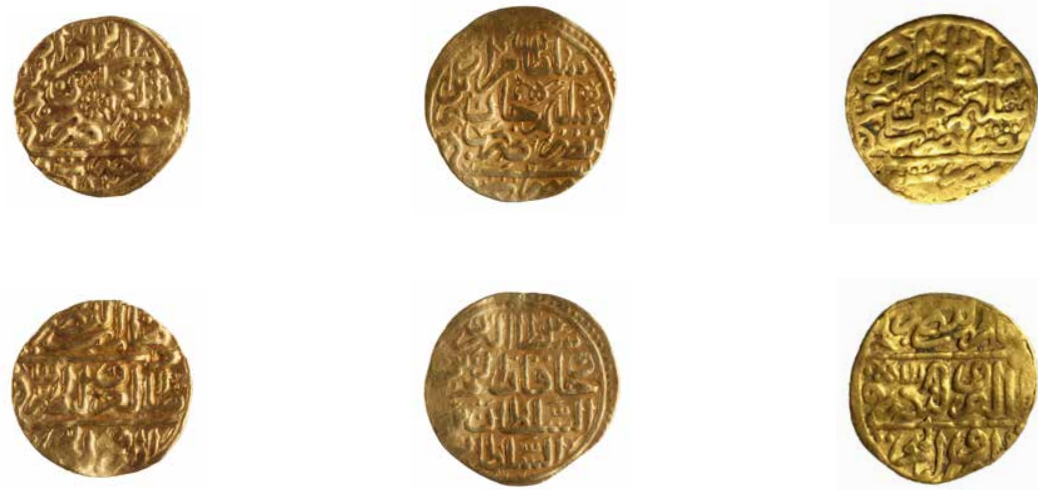

013

014

015
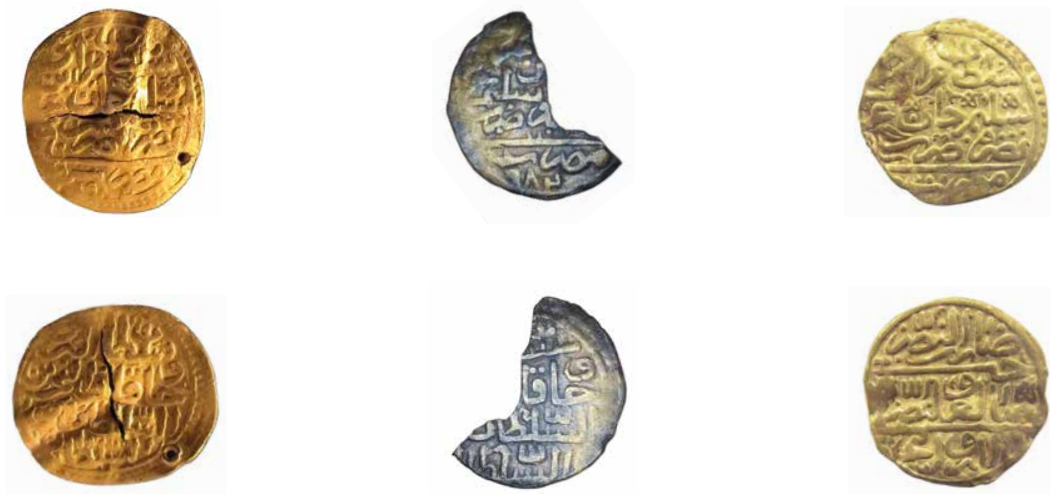

016

017

018 
Pl. 3
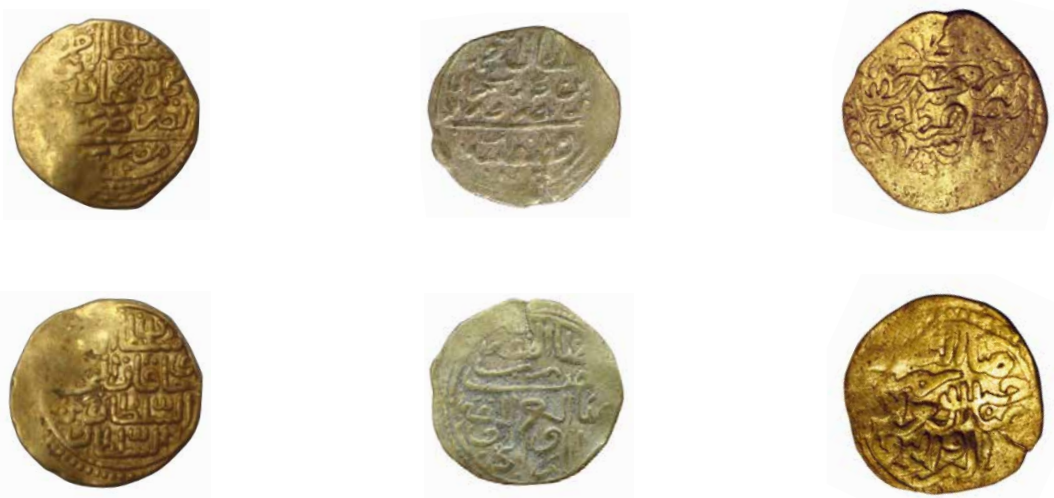

019

020

021
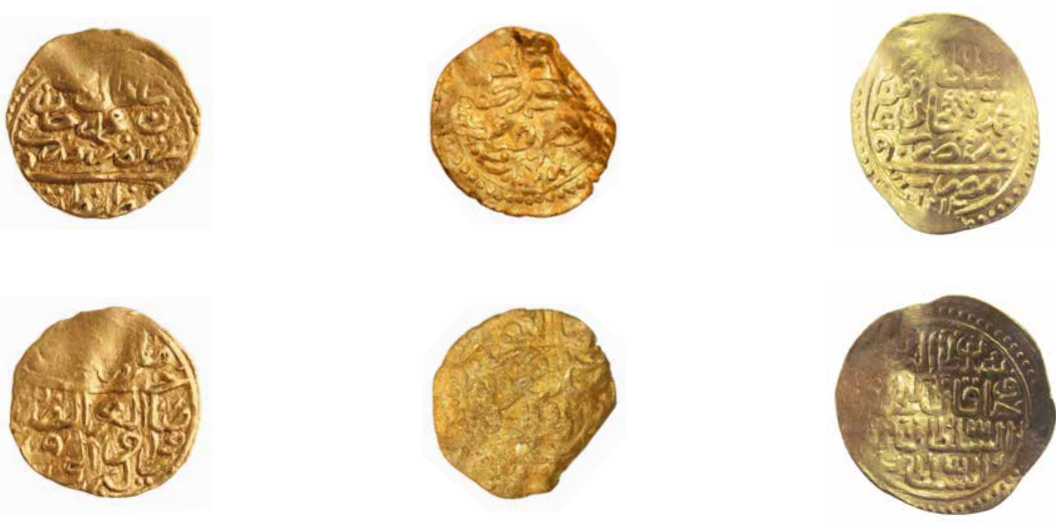

022

023

024
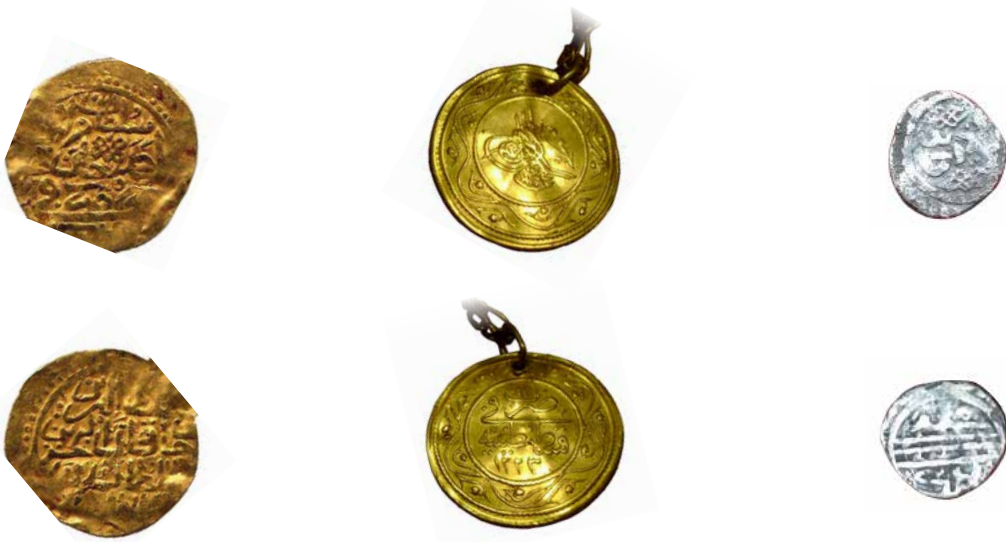

025

026

027 
Pl. 4
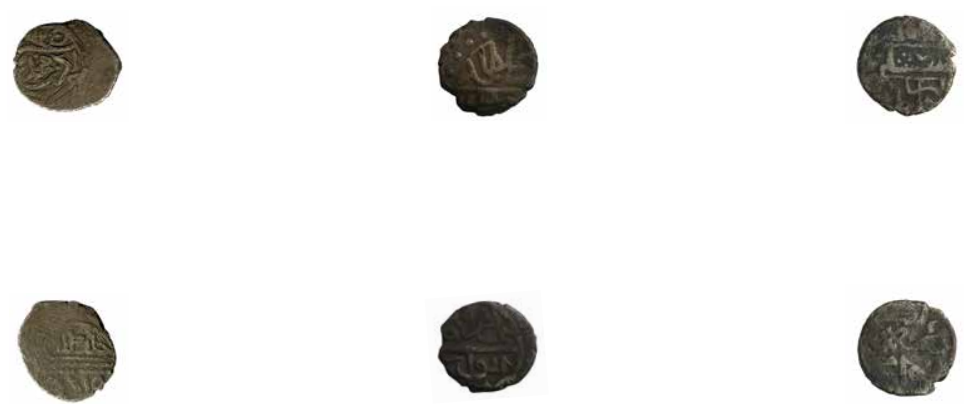

029

032
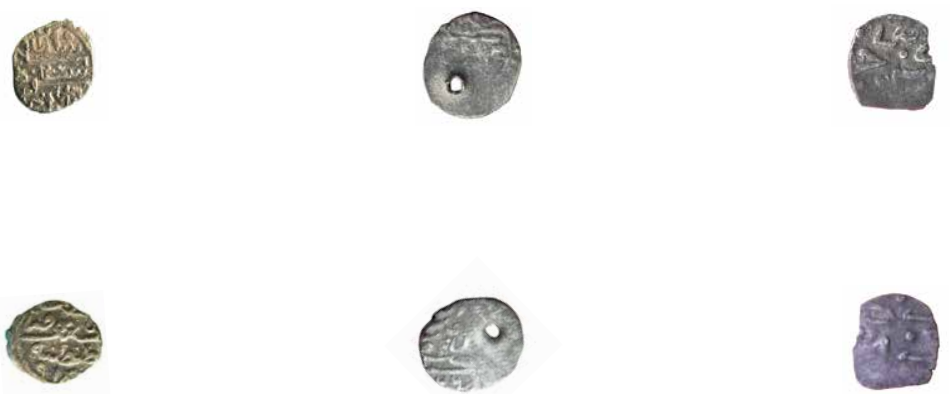

033

034

035

n
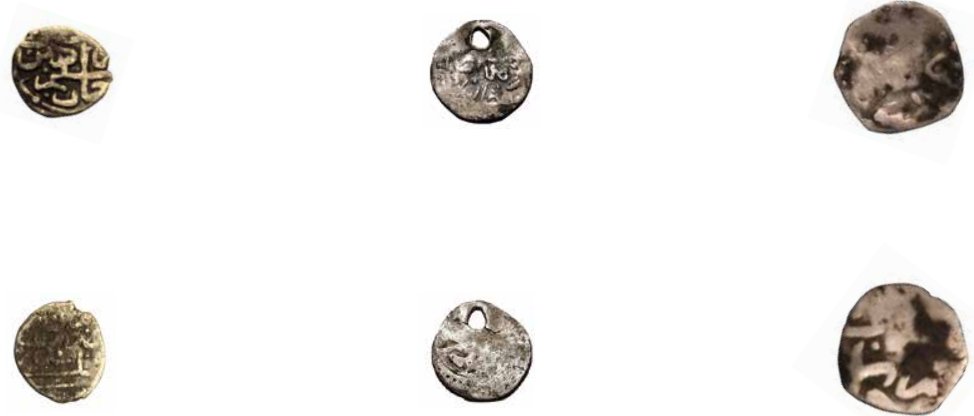

036

037

038 
Pl. 5
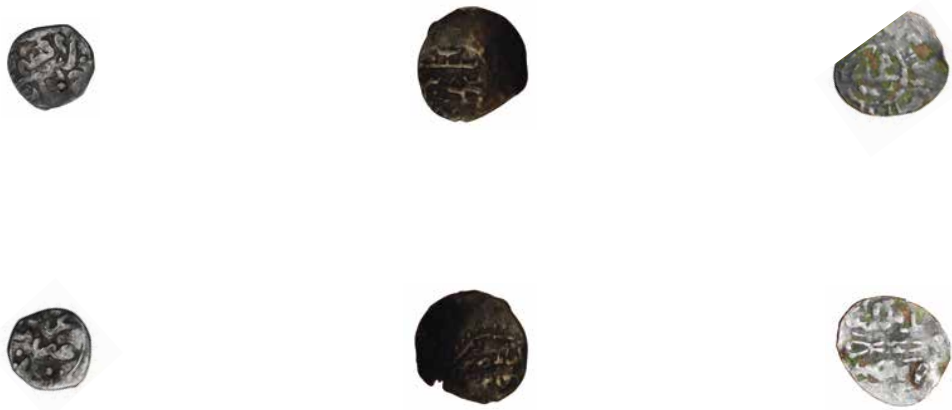

039

040

041
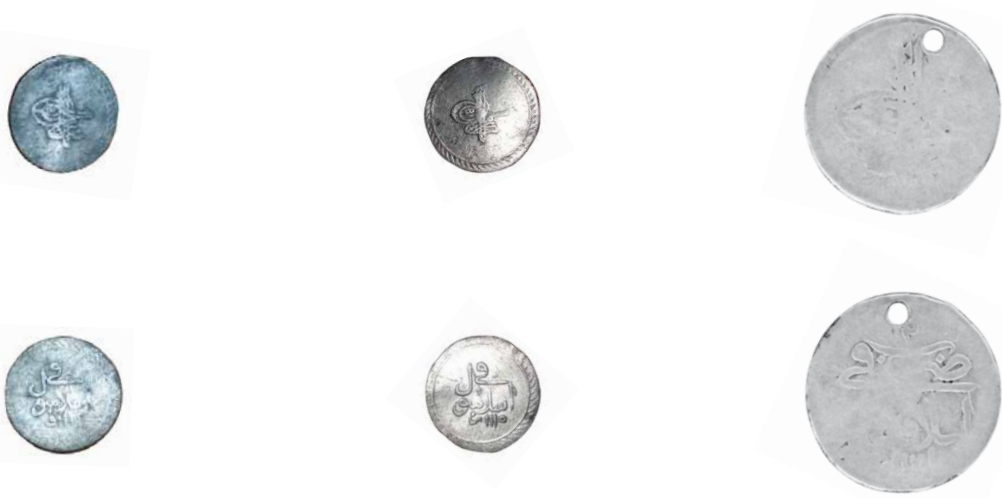

042

043

044
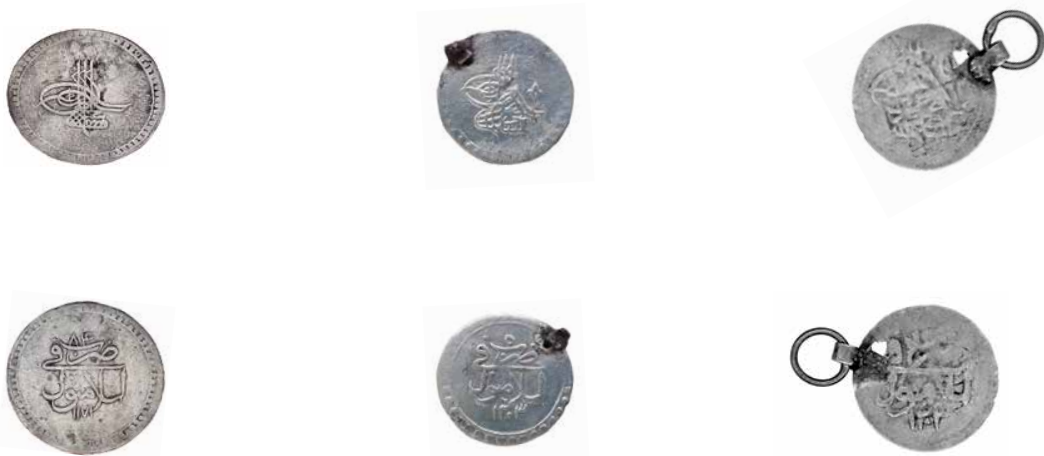

045

046

047 
Pl. 6
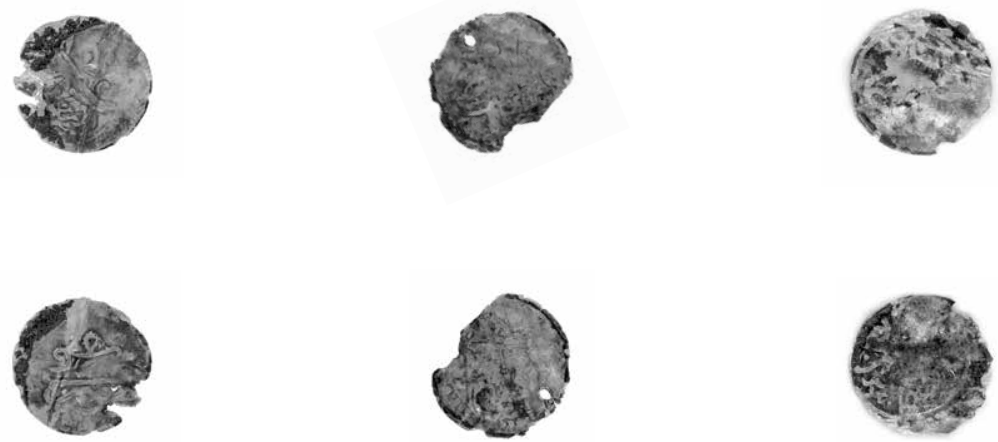

048

049

050
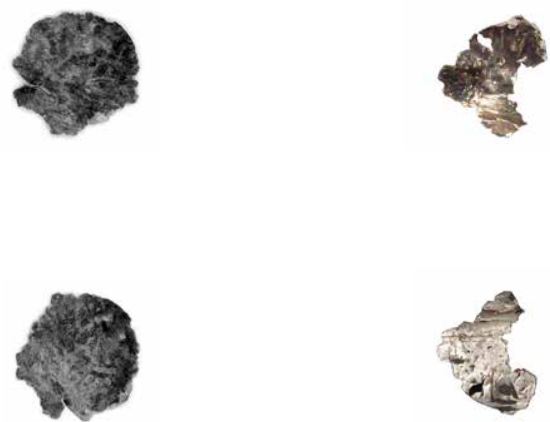

051

052

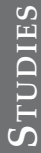
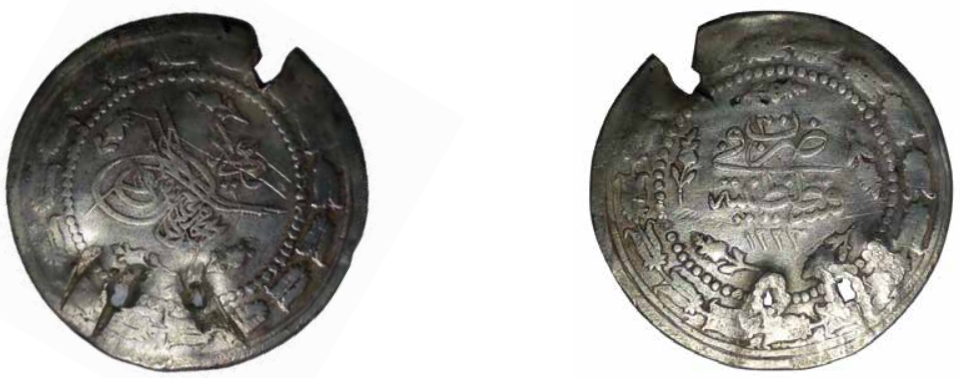

053 
Pl. 7
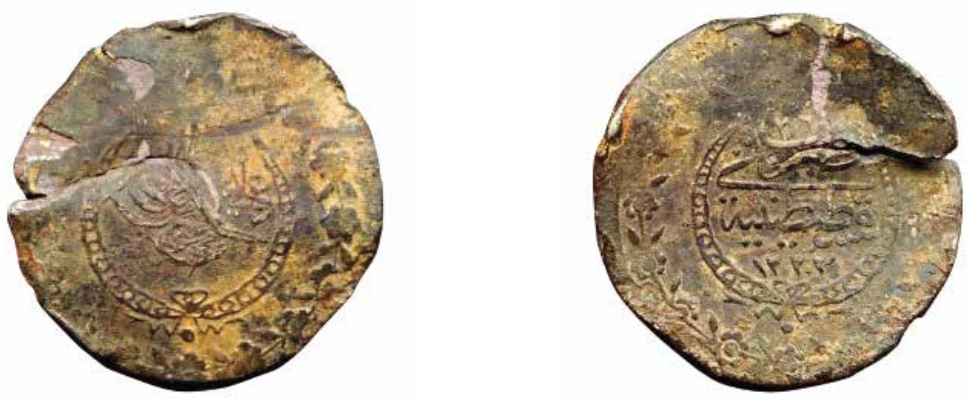

054
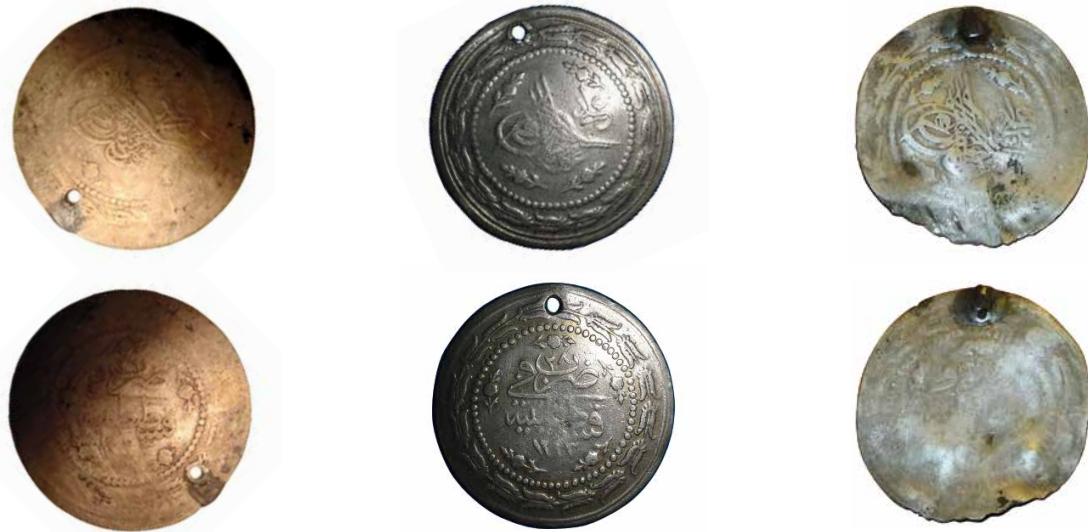

055

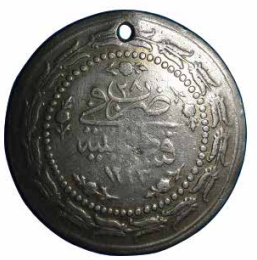

056

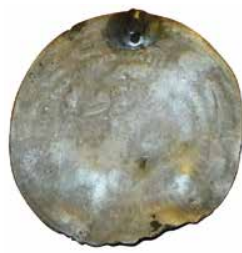

\section{7}
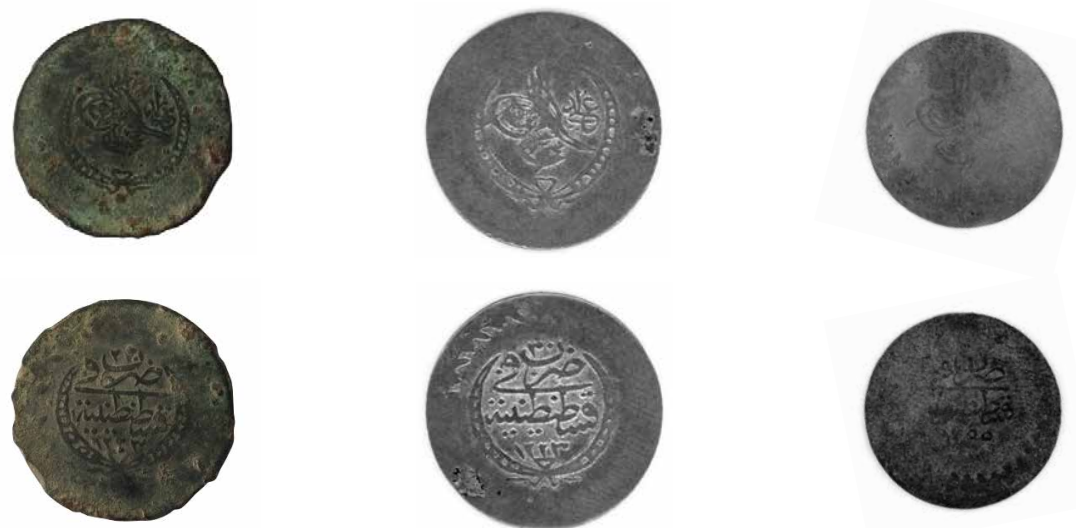

058
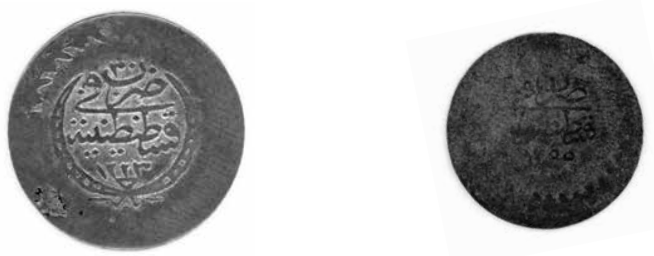

059

060 


\section{Pl. 8}
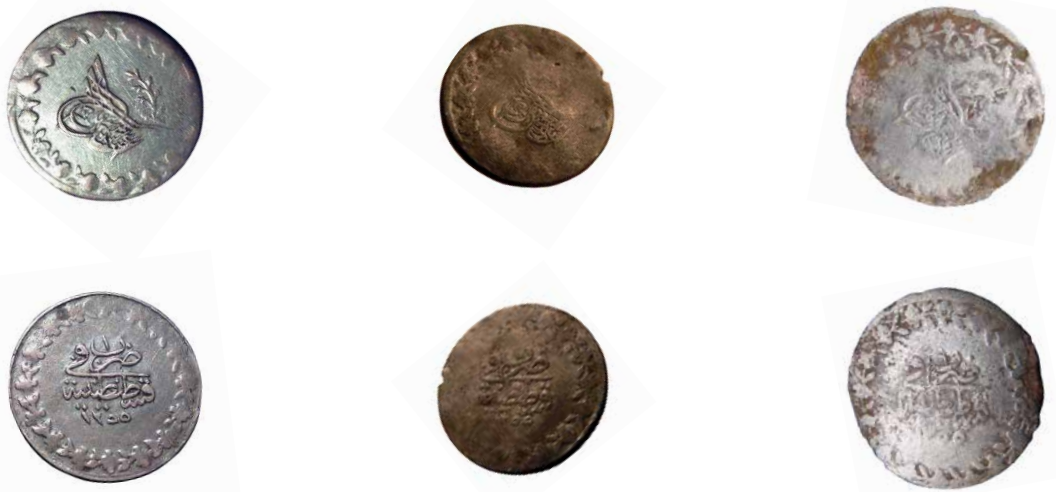

061

062

063
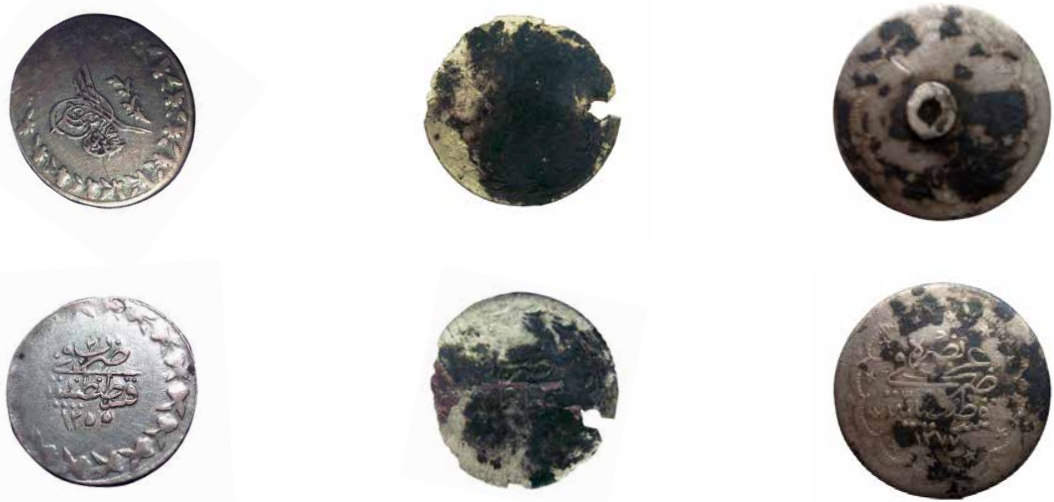

064

065

066
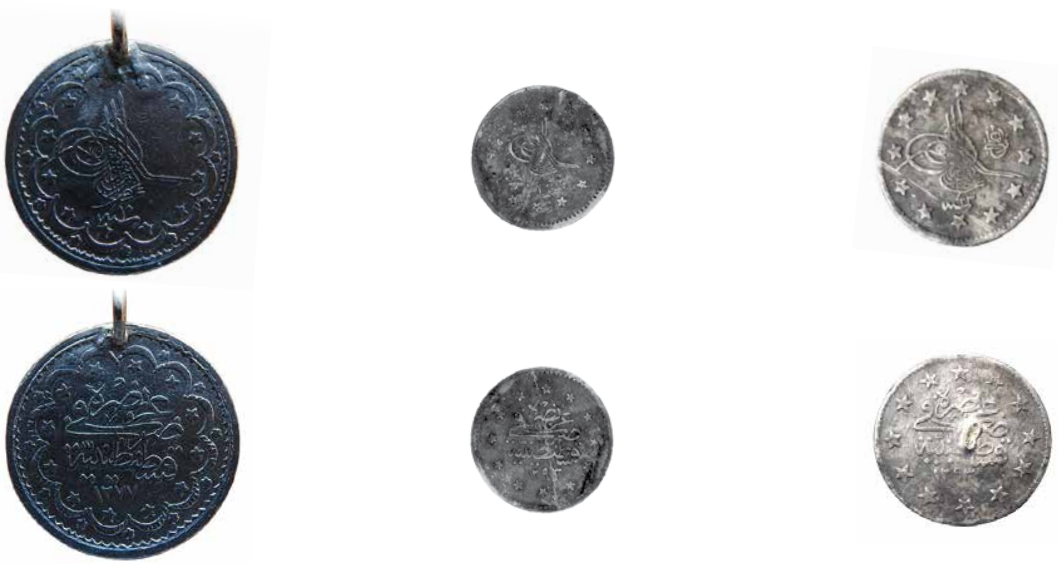

068

069 
Pl. 9
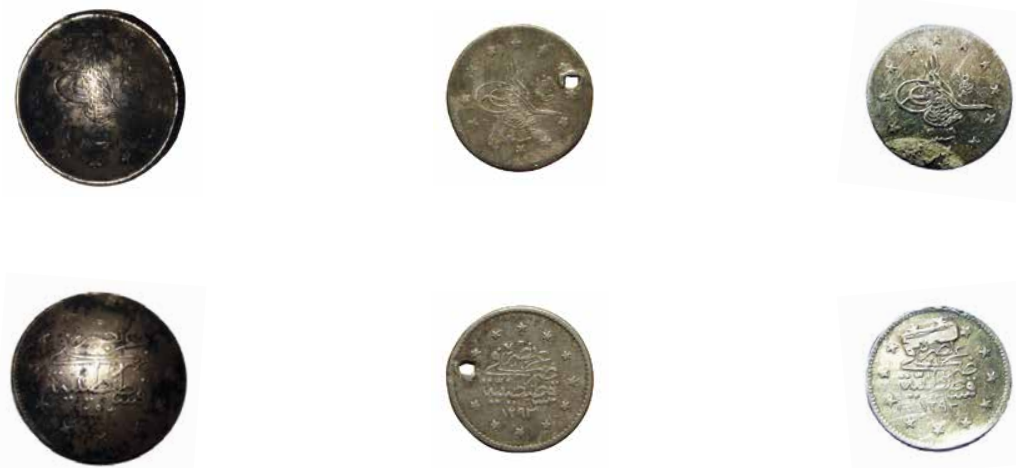

070

071

072
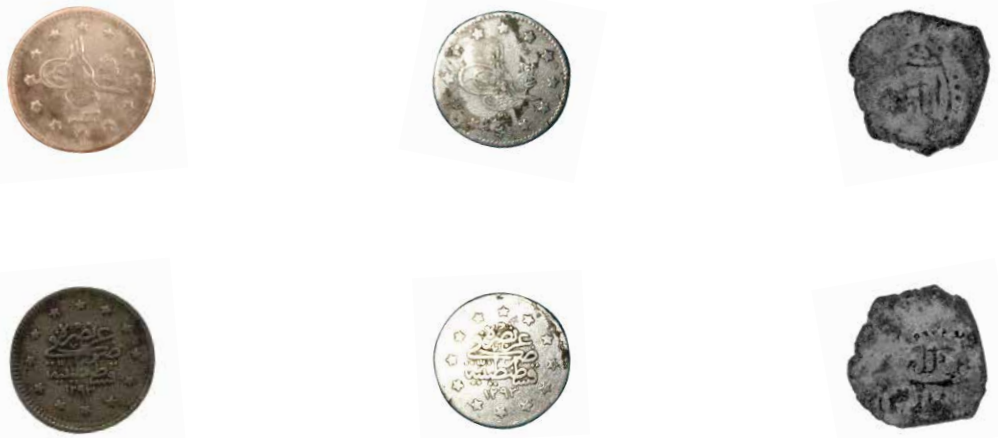

073

074

075
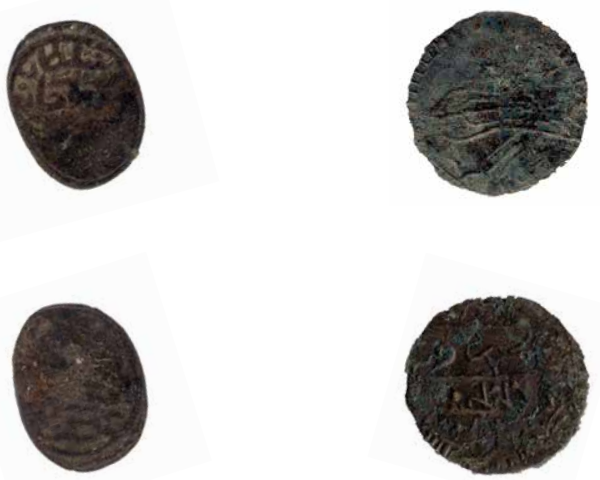

076

077 
Pl. 10
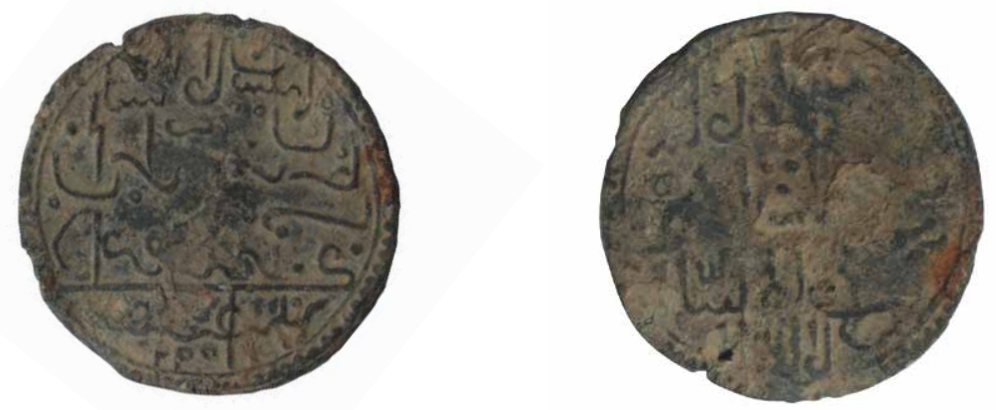

078
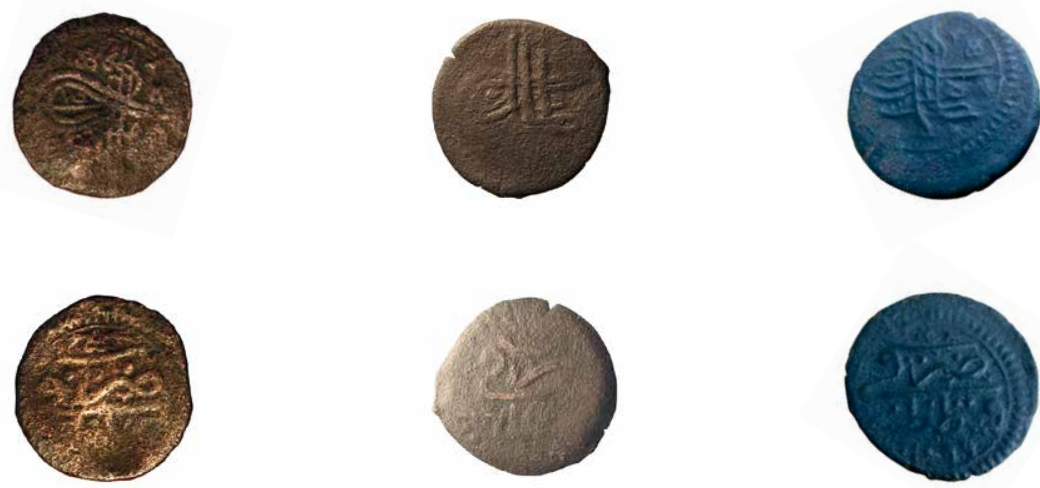

079

080

081
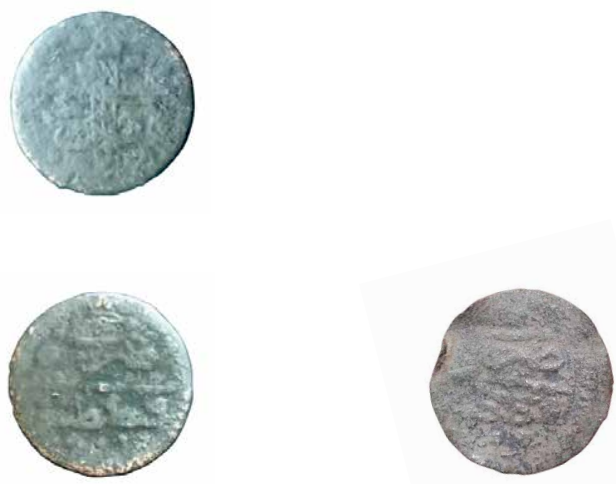

083

084 
Pl. 11
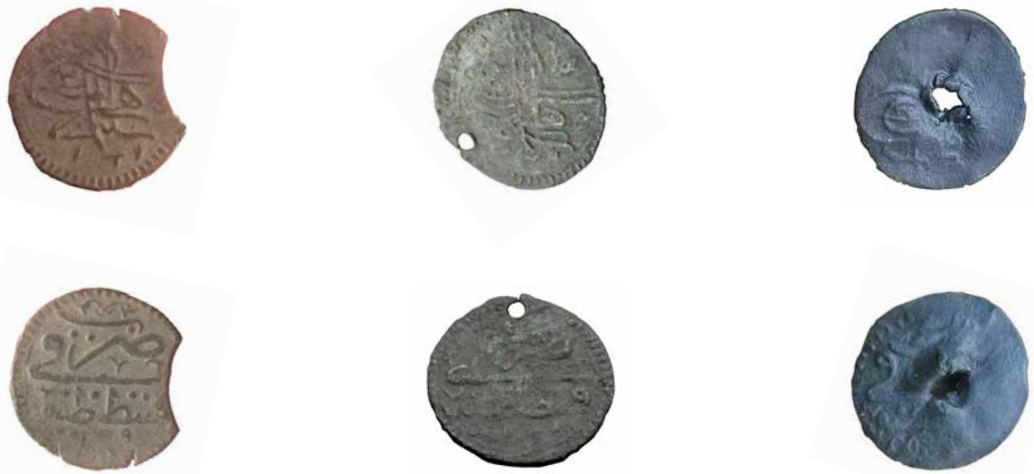

085

086

087
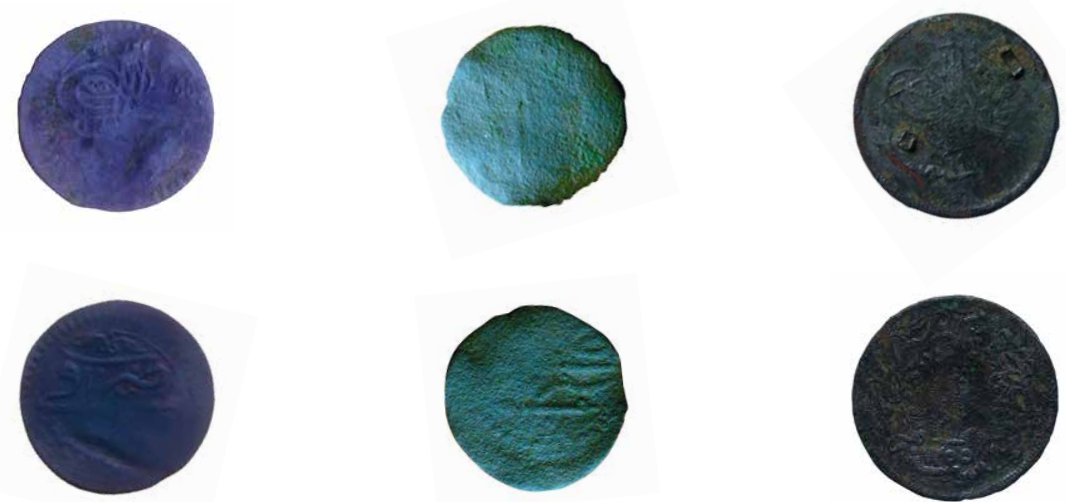

088

089

090
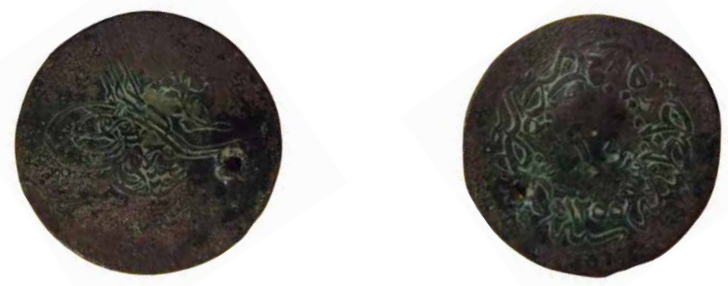
Pl. 12
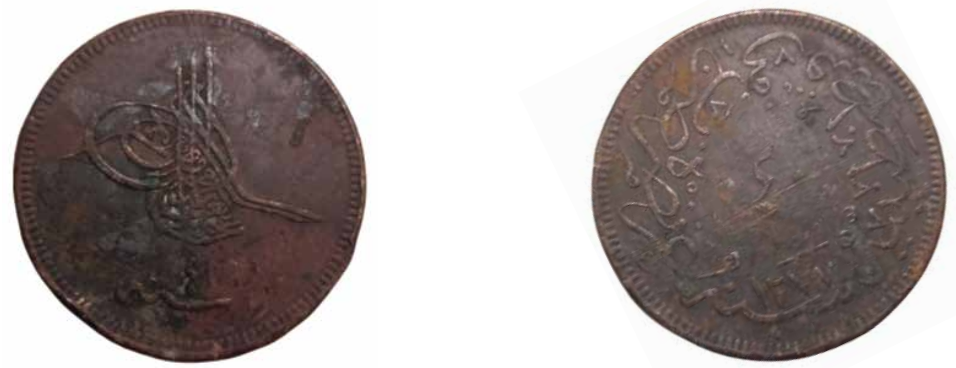

092
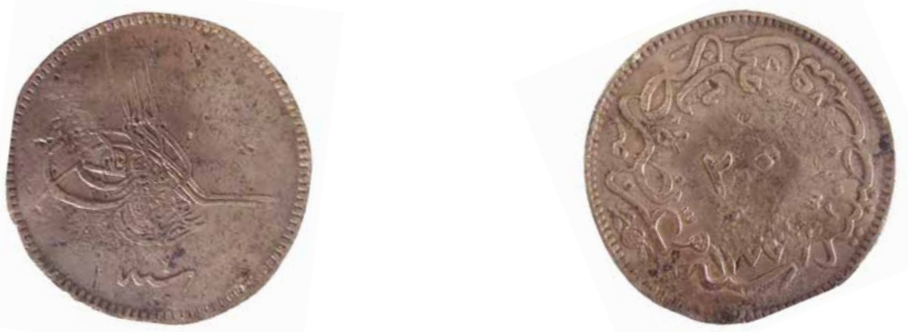

093

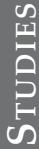

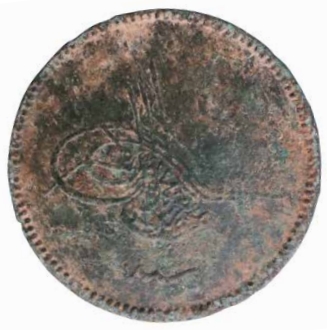

094 
Pl. 13

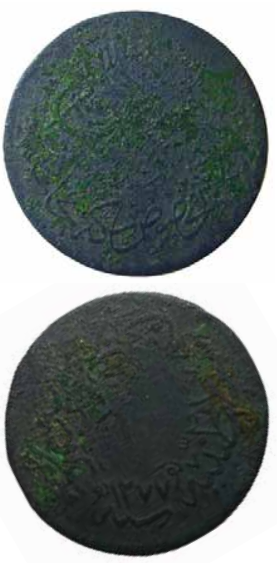

095
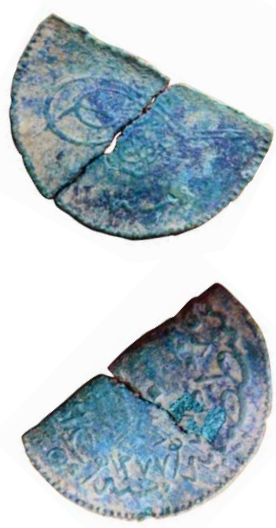

096
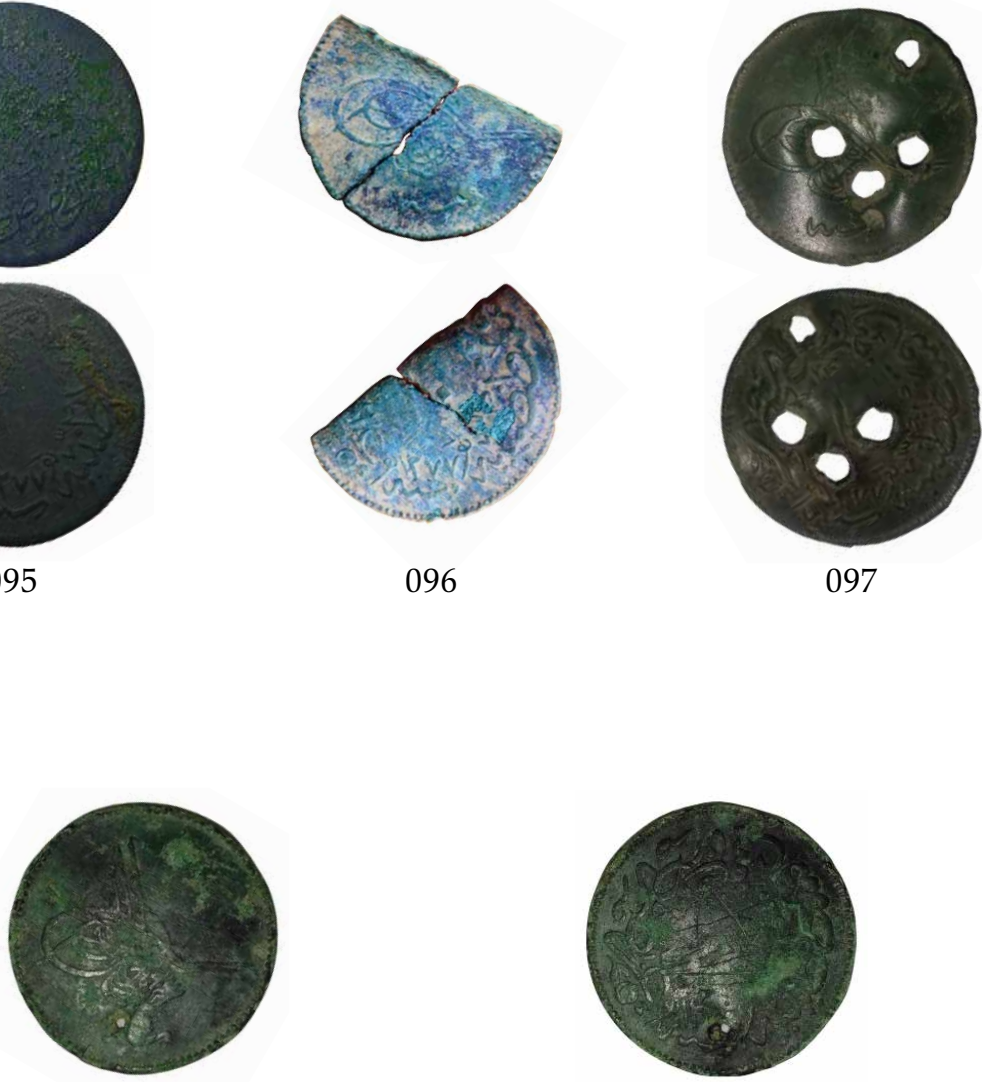

098
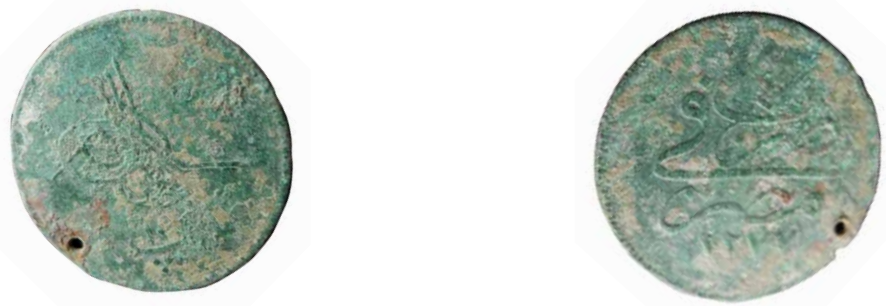
Pl. 14
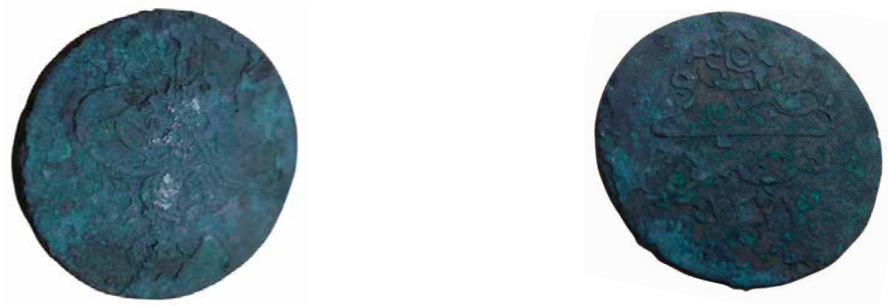

100
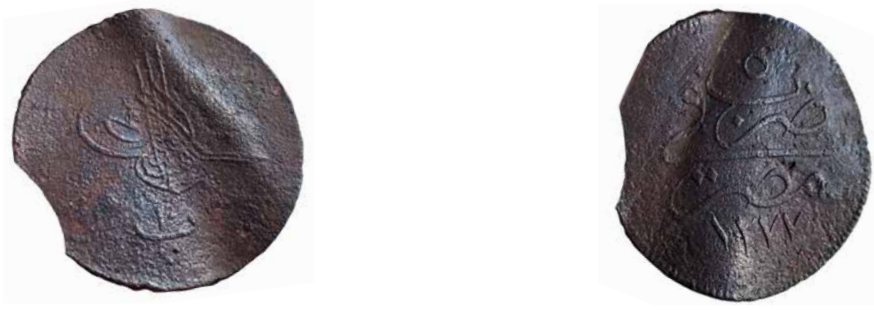

101
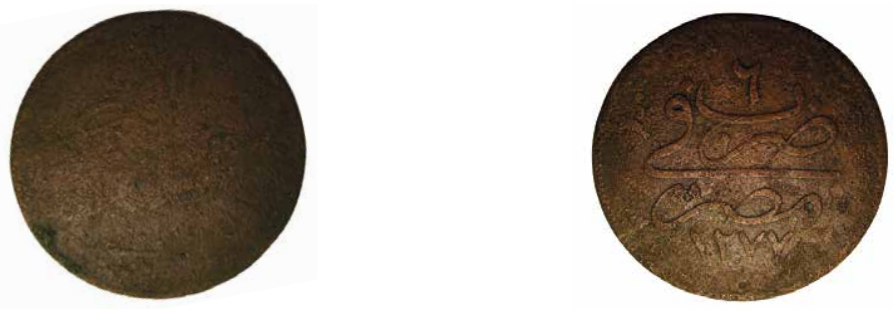
Pl. 15
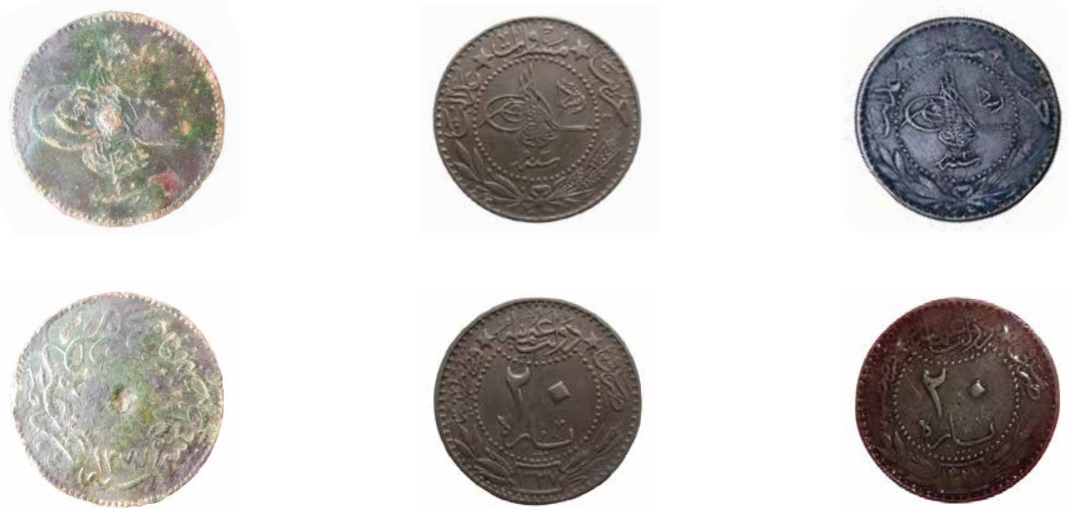

103

104

105
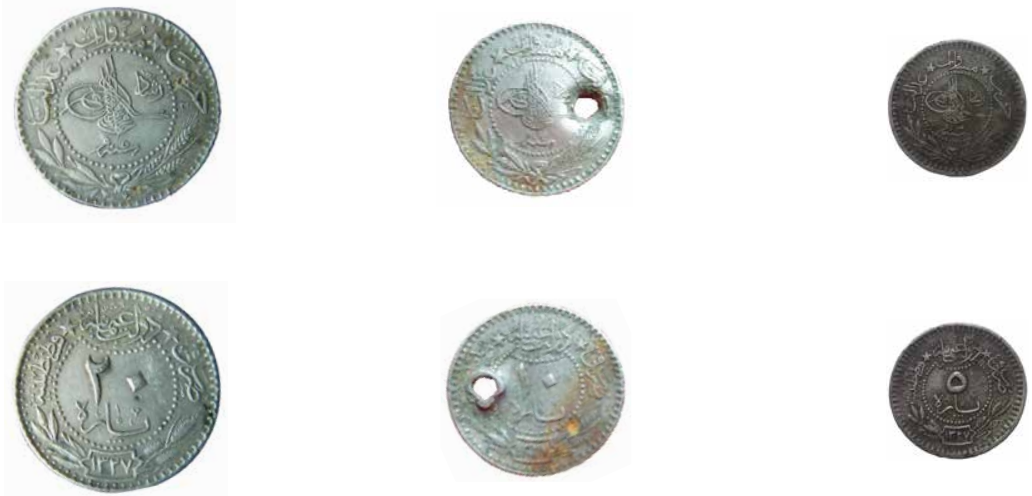

106

107

108
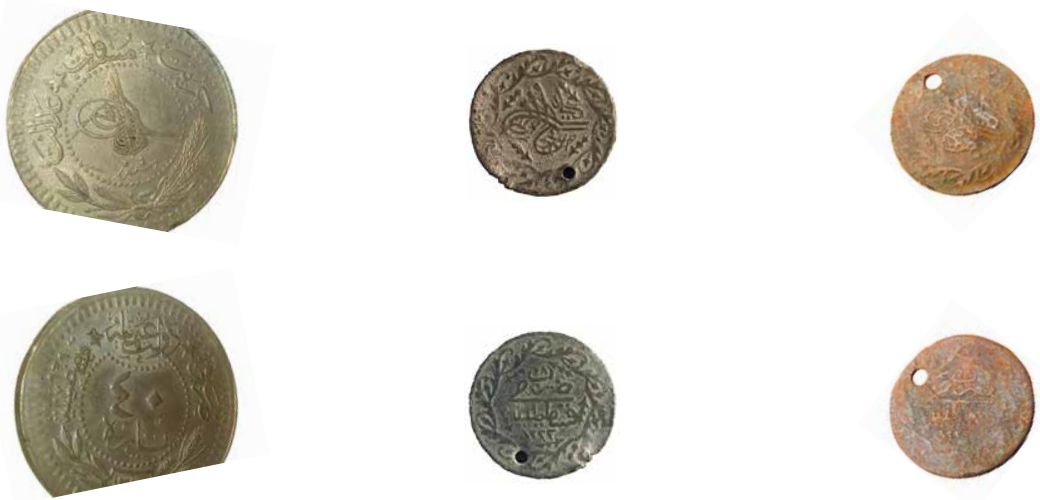

109

110 
Pl. 16
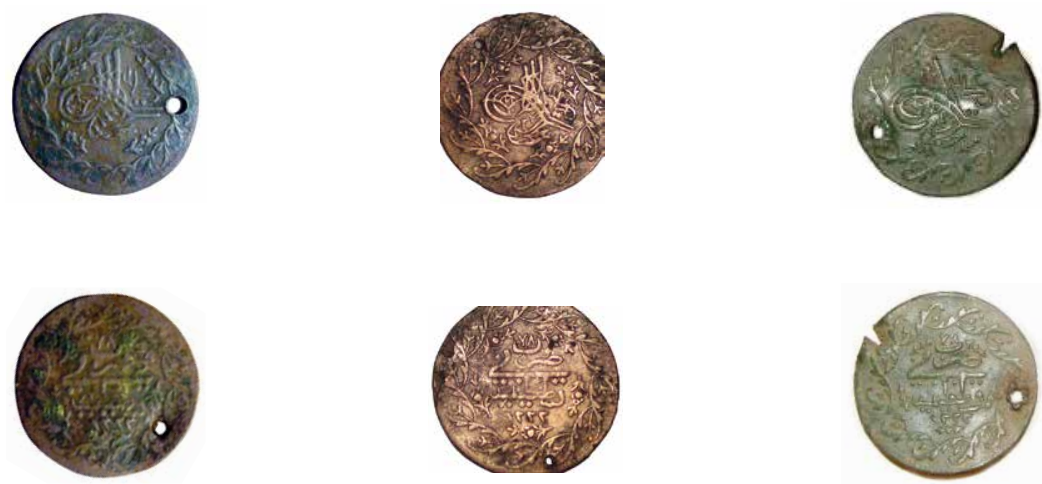

112

113

114
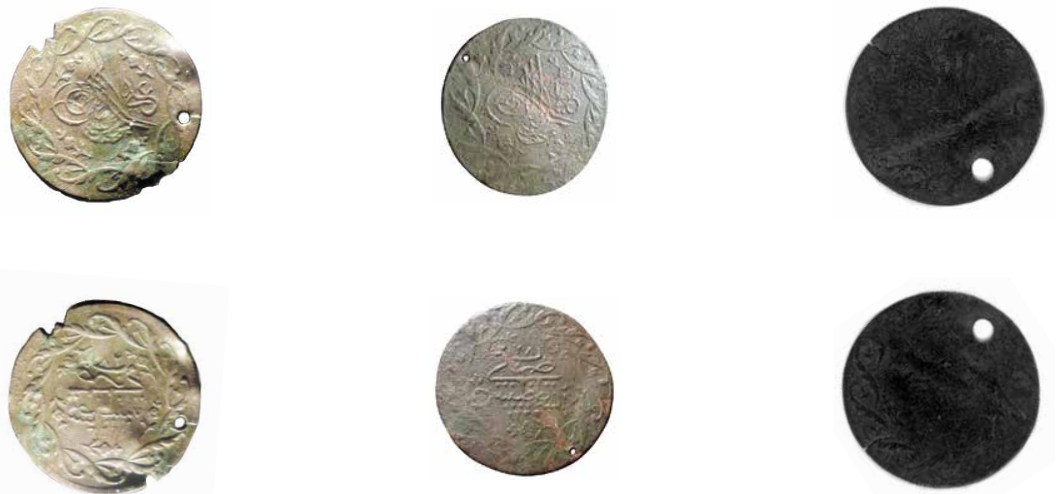

115

116

117

品 